\title{
Cytokinetic analysis of lung cancer
}

Citation for published version (APA):

Tinnemans, M. M. F. J. (1996). Cytokinetic analysis of lung cancer. [Doctoral Thesis, Maastricht University]. Datawyse / Universitaire Pers Maastricht. https://doi.org/10.26481/dis.19960308mt

Document status and date:

Published: 01/01/1996

DOI:

10.26481/dis.19960308mt

Document Version:

Publisher's PDF, also known as Version of record

\section{Please check the document version of this publication:}

- A submitted manuscript is the version of the article upon submission and before peer-review. There can be important differences between the submitted version and the official published version of record.

People interested in the research are advised to contact the author for the final version of the publication, or visit the DOI to the publisher's website.

- The final author version and the galley proof are versions of the publication after peer review.

- The final published version features the final layout of the paper including the volume, issue and page numbers.

Link to publication

\footnotetext{
General rights rights.

- You may freely distribute the URL identifying the publication in the public portal. please follow below link for the End User Agreement:

www.umlib.nl/taverne-license

Take down policy

If you believe that this document breaches copyright please contact us at:

repository@maastrichtuniversity.nl

providing details and we will investigate your claim.
}

Copyright and moral rights for the publications made accessible in the public portal are retained by the authors and/or other copyright owners and it is a condition of accessing publications that users recognise and abide by the legal requirements associated with these

- Users may download and print one copy of any publication from the public portal for the purpose of private study or research.

- You may not further distribute the material or use it for any profit-making activity or commercial gain

If the publication is distributed under the terms of Article $25 \mathrm{fa}$ of the Dutch Copyright Act, indicated by the "Taverne" license above, 


\section{Cytokinetic analysis of lung cancer}




\section{CIP-DATA KONINKLIJKE BIBLIOTHEEK, DEN HAAG}

Tinnemans, Monique Maria Franciska Johanna

Cytokinetic analysis of lung cancer/Monique Maria

Franciska Johmna Tinnemans. - Mastricht : Universitaire

Pers Mastricht. - III.

Thesis Rijksuniversiteit Limburg, Maastricht - With ref. -

With summary in Dutch.

ISBN 90-5278-212-1

Subject headings: cell kinetics / lung cancer.

Cover illustration: vital cells of the MR65 lung tumor cell line. 


\title{
Cytokinetic analysis of lung cancer
}

\author{
Proefschrift
}

ter verkrijging van de graad van doctor aan de Rijksuniversiteit Limburg te Mastricht, op gezag van de Rector Magnificus, Prof. mr. M.J. Cohen, volgens het besluit van het College van Dekanen, in het openbaar te verdedigen op vrijdag 8 maart 1996 om 16.00 uur

door

Monique Maria Franciska Johanna Tinnemans

geboren op 22 juni 1967 te Roermond 
Promotores:

Prof dr. F.C.S. Ramaekers

Prof dr. G.H. Blijham (Universiteit Utrecht)

\title{
Co-promotores:
}

\author{
Dr. B. Schutte \\ Dr. G.P.M. ten Velde
}

Beoordelingscommissie:

Prof. dr. M.F. von Meyenfeldt (woorzitter)

Prof. dr. J.W. Arends

Dr. A.C. Begg (Nederlands Kanker Instituut, Amsterdam)

Prof, dr. H.F.P. Hillen

Prof. dr, $\mathbb{E}$. Wouters

The investigations described in this thesis were carried out at the Department of Molecular Cell Biology \& Genetics, University of Limburg, Maastricht.

The project was financially supported by the Dutch Cancer Society.

Publication of this thesis was partially financed by

Bio-Rad Laboratories

Bristol-Myers Squibb B.V.

Euro-Diagnostica B. Y.

Rhône Poulenc Rorer B. V.

Stichting Ontwikkeling en Kennis Pulmonologie, University Hospital Maastricht. 
Every cell has a dream, and this dream is to divide

E. Nigg 

Contents

List of abbreviations

Chapter One

General Introduction

9

Part l

Clinical relevance of cell cycle paraneters in the lung

Chapter Two

Cytokinetic analysis of lung cancer by in vivo bromodeoxyuridine labeling

Chapter Three

Prognostic value of cytokinetic parameters in lung cancer

after in vivo bromodeoxyuridine labeling.

Chapter Four

Evaluation of proliferation parameters in in vivo bromo-

deoxyuridine labeled lung cancers

Pant II

Methodological aspects of proliferation and cell loss measurements:

Chapter Five

Three parameter flow cytometric analysis: Simultaneous detection of cytokeratin, proliferation associated antigens and DNA content

Chapter Six

S-phase arrest of nutrient deprived lung cancer cells

Chapter Seven Alterations in cytoskeletal and nuclear matrix associated proteins during apoptosis

Chapter Eight

Summary and general discussion

Samenvatting

Dankwoord

Curriculum Vitae 


\section{List of abbreviations}

\begin{tabular}{|c|c|}
\hline$A C$ & adenocarcinoma \\
\hline $\mathrm{Ag}$ & antigen \\
\hline bp & basepairs \\
\hline $\mathrm{BP}$ & bandpass \\
\hline Brdu & 5-bromo-2'-deoxyuridine \\
\hline BSA & bovine serum albumin \\
\hline $\mathrm{CHX}$ & cycloheximide \\
\hline $\mathrm{CV}$ & coefficient of variation \\
\hline ED & extensive disease \\
\hline FACS & fluorescence activated cell sorter \\
\hline FCM & flow cytometry \\
\hline FITC & fluorescein isothiocyanate \\
\hline $\lg$ & immunoglobulin \\
\hline ISNT & in situ nick translation \\
\hline $\mathrm{kb}$ & kilobase \\
\hline $\mathrm{kbp}$ & kilobasepairs \\
\hline $\mathrm{kDa}$ & kiloDalton \\
\hline LCLC & large cell lung carcinoma \\
\hline LD & limited disease \\
\hline $\mathrm{LI}$ & labeling index \\
\hline$L P$ & longpass \\
\hline $\mathrm{nm}$ & non-malignant \\
\hline NSCLC & non-small cell lung carcinoma \\
\hline PBS & phosphate buffered saline \\
\hline PCNA & proliferating cell nuclear antigen \\
\hline $\mathrm{PF}^{\mathrm{w}}$ & phycoetythrin \\
\hline PI & propidium iodide \\
\hline RM & relative movement \\
\hline $\mathrm{RT}$ & room temperature \\
\hline SCLC & small cell lung carcinoma \\
\hline SDS & sodium dodecylsulphate \\
\hline $\mathrm{SPF}$ & S-phase fraction \\
\hline $\mathrm{SQCC}$ & squamous cell carcinoma \\
\hline SSC & standard saline citrate \\
\hline$T_{p a t}$ & potential tumor doubling time \\
\hline $\mathrm{T}_{\sharp}$ & S-phase transit time \\
\hline USPF & unlabeled S-phase fraction \\
\hline
\end{tabular}


General Introduction 


\section{General Introduction}

\section{Epidemiology}

Lung cancer has become the most common tumor in the world today, with a worldwide increase in incidence and mortality in the past decades. In men, lung cancer is the most frequently occurring cancer and in women, it is third after breast cancer and cancer of uterine cervix ${ }^{11,33}$. Accounting for $28 \%$ of all cancer deaths in the United States ${ }^{46}$ and for over $35 \%$ in the Netherlands ${ }^{11}$, lung cancer is the number one killing malignancy in both men and women ${ }^{24}$. In the male population, the number of deaths due to lung cancer has increased since the 1940 s, and in the female population an increase was seen starting from the rnid-sixties ${ }^{17}$. Since the early 1980 s however, a stabilization in lung cancer mortality amongst men became manifest while nowadays, a decreasing trend is observed in this population ${ }^{11}$. In women however, death rates caused by lung cancer continue to increase.

The etiology of lung cancer appears to be multifactorial, although tobacco use is generally believed to be the strongest causal factor ${ }^{17,20,37,4,42,43}$. Female smokers were found to be at higher risk for the development of lung cancer than male smokers, possibly due to an increased susceptibility ${ }^{36}$.

\section{Histopathology and staging}

The revised report of the World Health Organization ${ }^{47}$ on histologic typing of lung tumors distinguishes four major types of lung cancer, i.e. squamous cell carcinoma, adenocarcinoma, large cell undifferentiated carcinoma and small cell undifferentiated carcinoma. The first three types are collectively referred to as non-small cell lung carcinoma (NSCLC), whereas the latter type is referred to as small cell carcinoma (SCLC). Lung tumors are usually staged according to the modified TNM classification $^{27}$, considering tumor size (T designation), presence of lymph node metastases ( $\mathrm{N}$ designation) and distant metastases ( $\mathrm{M}$ designation).

Along with the increase of lung cancer incidence in industrialized countries, the relative proportion of the four sublypes has changed in the last decades, showing a relative increase in adenocarcinoma and a decrease in squamous cell carcinoma ${ }^{12}$. All four subtypes of lung cancer exhibit different growth patterns and different survival rates. Squamous cell carcinoma represents 30 to $40 \%$ of the lung carcinomas and is generally reported to have a better prognosis than adenocarcinoma, which accounts for 25 to $30 \%$ of lung malignancies ${ }^{17}$. Approximately $20 \%$ of all lung carcinomas are of the SCLC type, which is known for its agressive behavior and which, if untreated, results in a short patient survival time. The remaining group of lung carcinomas is 
represented by the large cell undifferentiated carcinoma and mixed types of lung cancer, that can display features of several of the other subtypes. In general, patients presenting with large cell undifferentiated carcinoma do better than those with SCLC, but have a worse prognosis than patients with adenocarcinoma or squamous cell carcinoma.

The major advances in our understanding of the biology of both SCLC and NSCLC have not led to considerable improvements in treatment results, since the overall survival rates of lung cancer patients remained practically unchanged during the past two decades ${ }^{6,28}$.

\section{Prognostic determinants}

The factors most evidently related to the prognosis of lung cancer patients are the histology subtype and the stage of disease at the time of diagnosis ${ }^{15,16,39,40}$. Furthermore, from the wide range of predictive parameters that have been described until now, the most important factors are performance status of the patient ${ }^{13,16,40}$ and tumor size and location ${ }^{16,19}$. However, these parameters do not reflect the dynamics of tumor growth. Since existing therapies are mainly based on interference with cell cycle progression, detailed information on tumor growth characteristics may provide a basis for a more rational approach to the fine-tuning of treatment schedules.

\section{The cell cycle}

The life cycle of a eukaryotic cell consists of various phases, two of which can easily be identified. Firstly, during mitosis (M-phase), in which the cell divides into two genetically identical daughter cells, chromosome condensation and spindle formation are microscopically visible. Secondly, in S-phase the DNA of a cell is replicated, a process that can be detected using biochemical techniques. In-between these stages, there are two gaps in time, i.e. $G_{1}$, the gap between mitosis and the start of DNA. replication, and $\mathrm{G}_{2}$, the gap between completion of DNA replication and the onset of mitosis ${ }^{32}$. From $G_{1}$-phase a cell can leave the cell cycle and enter a "quiescent" phase called $G_{0}{ }^{3 n}$. The fate of these quiescent cells is three-fold: either 1) they re-enter the active cell cycle after a certain period of time, or 2 ) they undergo terminal differentiation and remain in $G_{0}$, or 3 ) cells are lost from this fraction due to cell death.

When the relative distribution of cells amongst the various cell cycle phases is determined, the $G_{0}$-phase can not be discriminated from the $G_{1}$-phase based on DNA content. Therefore, in flow cytometric analyses these phases are often referred to as $G_{0} / G_{1}$-phase. Since cells that cease proliferation, either reversibly or pemanently, come to arrest in $G_{0}$, the estimated duration of the $G_{0} / G_{1}$-phase is highly variable. In 
contrast, the duration of the $\mathrm{S}$-phase $(6-16 \mathrm{~h})$, the $\mathrm{G}_{2}$-phase $(4-8 \mathrm{~h})$ and the M-phase $\left(1-3\right.$ h) is relatively constant ${ }^{i x}$.

\section{Loss of cell cycle control in Iung cancer}

Regulation of the cell cycle predominantly occurs at three major control points, which govern the transition from $G_{0}$ to $G_{1}$, from $G_{1}$ to $S$ and from $G_{2}$ to $M$-phase. Passage through these controll points requires accurately timed activation and inactivation of a series of cyclin dependent kinases (CDKs) $)^{2,29}$. These CDKs trigger a cascade of biochemical events by phosphorylation of key molecules, such as the retinoblastoma (Rb) gene product. The activity of the CDKs is modulated by different cyclins ${ }^{29}$ and by specific inhibitory proteins ${ }^{34}$ such as $\mathrm{p} 16, \mathrm{p} 21$ and $\mathrm{p} 27$, which were recently found to be defective in malignancies, including lung cancers ${ }^{25}$. Cyclin DI overexpression in NSCLC cell lines and a considerably decreased level of the Rb gene product in SCLC cell lines, as compared to a normal bronchoepithelial cell line, were reported by Schauer et $\mathrm{al}^{3{ }^{38}}$. Harbour et al. ${ }^{18}$ reported mutation-induced loss of function of the $\mathrm{Rb}$ gene in SCLC.

In normally growing tissues, cell proliferation and cell loss are in balance. A dysfunctional cell cycle regulation can lead to a disturbance of tissue homeostasis by either increasing cell proliferation or decreasing cell loss, or both. An important process determining the rate of cell loss is programmed cell death (apoptosis). Apoptosis is regulated by various gene products such as bcl-2,p53 and c-myc. Overexpression of

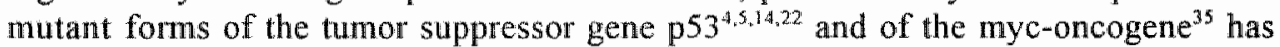
been frequently described in lung cancer. Furthermore, the bcl-2, p53 and c-myc genes were found to be defective or mutated in human cancers resistant to anti-neoplastic agents ${ }^{21}$. It is evident that, in order to obtain information the growth of a tumor, methods to measure cell proliferation as well as apoptosis are required.

\section{Proliferation parameters}

Many proliferation assays will only provide information on the cell cycle phase distribution of the cells, and not about the rate at which they progress. Such static proliferation measurements include the flow cytometric quantification of the S-phase fraction or the immunohistochemical evaluation of cells positive for proliferation associated markers. For example. Proliferating Cell Nuclear Antigen (PCNA) is detected in $S$-phase cells under appropriate fixation conditions and the Ki67-antigen has been described to occur in all phases of the cell cycle except for $G_{0}$. However, cell proliferation is not only determined by the number of cells participating in the cell cycle, but also by the rate at which the cells proceed through the various phases. Therefore, additional information about dynamic parameters such as $\mathrm{S}$-phase duration 
and potential doubling time of the tissue is required. In addition to the formerly mentioned proliferation markers, we determined cytokinetic parameters using in vivo incorporation of the thymidine analogue bromodeoxyuridine (BrdU). BrdU is incorporated into the newly synthesized DNA of S-phase cells and can be visualized by an anti-BrdU monoclonal antibody. By allowing some time to elapse between the in vivo administration of BrdU and the bronchoscopy, it is possible to obtain static proliferative information (such as the number of cells in S-phase) as well as dynamic proliferative information (such as the S-phase transit rate and the potential doubling time) by means of bivariate BrdU/DNA flow cytometric analysis ${ }^{3}$.

\section{Quantification of apoptosis}

To date, the most generally accepted procedure to detect apoptosis is microscopical identification based on morphologic changes in the cell nucleus and cytoplasm ${ }^{48}$. However, measurement of apoptosis in tissue using this method is rather subjective and time-consuming. In the past years, various alternative methods for the detection of apoptosis have been described, for example the biochemical detection of $200 \mathrm{bp}$ DNA fragments and multiples thereof, which are the result of specific internucleosomal DNA cleavage during apoptosis'. However, using this method, no information is obtained on a per cell basis. Furthermore, recent data provide evidence that apoptosis is not always accompanied by such DNA laddering ${ }^{7,8,30}$. The induced DNA "nicks" can also be detected by in situ end labeling ${ }^{10,23,45}$. A disadvantage of this technique is that it does not discriminate between apoptotic and necrotic cells. Furthermore, flow cytometric detection methods have been described based on amongst others changes in cell scatter properties and loss of DNA content (reviewed by Vermes and Haanen ${ }^{44}$ ). However, these techniques often do not discriminate between apoptotic and necrotic cells on the one hand, or between apoptotic and vital cells on the other hand. A new approach is based on loss of membrane asymmetry during apoptosis, resulting in exposure of phosphatidylserine residues at the outer cell membrane, without loss of membrane integrity. The feasibility of this approach has been described for non-solid tissue samples ${ }^{26}$.

\section{Aim of the present study}

It may be apparent that information on cell proliferation can be of use in monitoring and predicting lung tumor growth. In part $I$ of this thesis we have evaluated and compared several proliferation parameters in a large series of bronchoscopy specimens. These markers were correlated with clinicopathological features, resulting in the identification of predictors of clinical outcome. From these studies, several pitfalls regarding the methodology became apparent. Part $I I$ addresses some of these pro- 
blems. We have pursued the development of methods that allow the quantification of cell proliferation and cell loss exclusively in the tumor cell population. 


\section{References}

1 Arends MJ, Morris RG, Wyllie AF: Apoptosis. The role of the endonuclease Am I Pathol 136:593-608 (1990).

2. Barinaga $M$ : A new twist to the cell cycle. Science 269:631-632 (1995).

3 Begg AC, McNally NY, Schrieve DC, Karchner H: A method to measure the duration of DNA synthesis and the potential doubling time from a single sample. Cyometry 6:620-626 (1985).

4 Bodner SM, Minna JD, Jensen SM, D'A mico D, Carbone D, Mitsudonu T. Fedorko J, Buchluagen DL, Nau MM, Gazdar AF, Linnoila RI: Expression of mutant p53 proteins in lung cancer correlates with the class of 553 gene mutation. Oncogene 7:743-749 (1992).

5 Caamano J, Ruggeri B, Momiki S, Sickler A, Zhang SY, Klein-Szanto AJP: Detection of p53 in primary lung tumors and nonsmall cell lung carcinoma call lines. Am If Pahol 139:839-845 (1991).

6 Camey DN. The biology of lung cancer Curr Opin Oncol 4:292-298 (1992).

7 Cohen GM, Sun X-M, Srowden T, Dinsdalle D, Skilleier DN: Key morphological leatures of apoptosis may occur in the absence of internucleosonal DNA fragnnentation. Biochem I $286: 331-334$ (1992).

8 Collins RJ, Harmon BV, Gobe GC, Kerr JFR: Internucleosomal DNA cleavage should not be the sole criterion for identifying apoptosis. Int J Radiat Biol $61: 451-453$ (1992).

9 Cordon-Cardo $C$ : Mutation of cell cycle regulators. Biological and clinical implications for human neoplasia. Am J Pathol 147:545-560 (1995).

10 Darzynkicwicz Z, Bruno S, Del Bino G, Gorczyca W, Hotz MA, Lassota P, Traganos F: Features of apoptotic cells measured by flow cytometry. Cyrometry 13:795-808 (1992).

Il Den Boer KT, Kallewaard M, Peeters PHM, Verbeek ALM: Sterfte door Iongkanker daall bij mannen en slijgt bij vrouwen. Ned Tijdschr Geneesk 139:1493-1497 (1995)

12 Devesa SS, Shaw GL, Blot WJ: Changing patterns of lung cancer incidence by histological type. Cancer Iepidemiol Biomarkers' Prev 1:29-34 (1991).

13 Dover R. Basic methods for assessing cellular proliferation. In: Assessment of cell prolfferation in clinical practice. Hall PA, Levison DA, Wright NA (eds). Springer-Verlag, London, pp 63-81 (1992).

14 Ebina M, Steinberg. SM, Mulshine JL, Linnoila RI: Relationship of p53 overexpression and upregulation of proliferating cell nuclear antigen with the clinical course of non-small cell lung cancer Cancer Res 54:2496-2503 (1994).

15 Feld R. Arriagada R, Ball DL, Mattson K, Sorensen JB : Prognostic factors in non-snall coll lung cancer: a consensus report. Lamg Cancer 7:3-5(1991).

16 Gail MH, Eagan RT, Feld R, Ginsberg R, Goodell B, Hill L, Carmack Holmis EC, Lukeman JM, Mountain CF, Oldham RK, Pearson FG, Wright PW, Latke WH and the Lung Cancer Study Group: Prognostic factors in patients with resected stage I non-small cell lung cancer. Cancer 54:1802-1813(1984).

17 Haque AK: Pathology of carcinoma of lung: an update on current concepts. I Thorac Imaging 7:9-20 (1991),

18 Harbour JW, Lai S-L, Whang.Peng J, Gazdar AF, Minna JD, Kaye FJ: Abnormalities in structure and expression of the buman retinoblastoma gene in SCLC. Science $241: 353-357$ (1988). 
19 Harpole DH, Herndon JE, Wolfe WG, Iglehart JD, Marks JR: A prognostic model of recurrence and death in stage I non-small cell lung cancer utilizing presentation, histopathology, and oncoprotein expression. Cancer Res 55:51-56(1995)

20 Harris JE: Cigarette smoking among successive birth cohorts of men and women in the United States during 1960-80. J Nan Cancer Ins $71: 473-479$ (1983).

21 Hickman JA: Apoptosis induced by anticancer dnugs. Cancer Metas Rev 11:121-139 (1992).

22 Iggo $R$, Gatter $K$. Bartek $J_{*}$ Lane $D$, Harris AL: Increased expression of mutant forms of $p 53$ oncogene in primary lung cancer. Lancet 335:675-679 (1990).

23 Jonker RR, Bauman JGJ, Visser JMW: Detection of apoptosis using non-radioactive in situ nick translation. In: New Dewelopments in Filow Cytomery. NATO Advanced Study Institutes Programme, Lectures Option C. CNRS, Villejuif, pp 30-31 (1992).

24 Kabat GC: Recent developments in the epidemiology of lung cancer. Semin Surg Oncol 9:73-79 (1.993).

Kamb A, Gruis NA, Weaver-Feldhaus J, Liu Q, Harshman K, Tavtigian SV, Stockert E, Day RS3rd, Johnson BE, Skolnick MH. A cell cycle regulator potentially involved in genesis of many tumor types. Scherreg 264:436-440 (1994).

26 Koopman $G$, Reutelingsperger CPM, Klujiten GAM, Keehnen RMJ, Pals ST, van Oers MHJ: Annexin $V$ for flow cytometric detection of phosphatidylserine expression on $\mathrm{B}$ cells undergoing apoplosis. Blood 84:1415-1420 (1994).

27 Mountain CF: A new international staging system for lung cancer. Chest 89:225S-233 (1986).

28. Mulshine $J \mathrm{~L}$, Glatstein E, Ruckdeschel JC. Treatment of non-small cell lung cancer. $J$ Clin Oncol 4:1704-171.5 (1986).

29 Nasmyth K: Control of the yeast cell cycle by the Cdc28 protein kinase. Curr Opin Cell Biol 5:166-179(1993).

30 Oberhammer F, Wilson JW, Dive C, Mornis ID, Hickman JA, Wakeling AE, Walker PR, Sikorska M: Apoptotic death in epithelial cells: cleavage of DNA to 300 and/or $50 \mathrm{~kb}$ fragments prior to or in the absence of internucleosomal fragmentation. EMBOJ 12:3679-3684 (1993). Pardee $A B: G_{1}$ events and regulation of cell proliferation. Science 246: 603-608. Pardee AB, Dubrow R, Hamlin JL, Kletzien RF: Animal cell cycle. Anm Rev Biochem 47:715750 (1978).

33 Parkin DM, Pisani P, Ferlay J: Estimates of the worldwide incidence of eighteen major cancers in 1985. Int J Cancer 54:594-606 (1993).

34. Peter M, Herskowitz I. Joining the complex. oychin-dependent kinase inhibitory proteins and the cell cycle. Cell 79:181-184 (1994).

35. Prins J, de Vries EGE, Mulder NH: The mye family of oncogenes and their presence and importance in small-cell lung carcinona and other tumour types. Anticancer Res 13:1373-1386 (1993).

36 Risch HA, Howc GR, Jain M, Burch JD, Holowaty $\mathbb{E}$, Miller AB: Are female smokers at higher risk for lung cancer than male smokers? Am J Eprdemol 138:281-293 (1993)

37 Royal College of Physicians: Hicalth or smoking? Follow-up report of the royal college of physicians, pp. 21-35. London: Pitman Publishing Company (1983).

38 Schauer IE, Siriwardana S, Langan TA, Sclafani RA: Cyclin DI overexpression vs, retinoblastoma inactivation: implications for growth control cvasion in non-small cell and small cell lung cancer. Proc Nall Acad Sci USA $911: 7827-7831$ (1994).

39 Silvestrini $R$, Muscolino $G$, Costa A, Lequaglie $C$, Veneroni S, Mezzanotte $G$, Ravasi $G$ : Could cell kinctics be a predictor of prognosis in non-small cell lung cancer? Lung Cancer 7:165-170 (1991) 
40 Stanley KE. Prognostic factors for survival in pationts with inoperable lung cancer. Nat Camcer Inst 65:25 (1980)

41 Stevens RG, Moolgavkar SH: A cohort analysis of hung cancer and smoking in British males. Atr J Epidemiol 119:624-641 (1984).

42 US Department of Health and Human Services: The Surgcon Generals report on nutrition ard human health. A repont of the Surgeon General. DHSS Publication CDC-89.84I I. Washington, DC: Office on smoking and health (1989).

43. US Surgeon General: The health consequences of snoking, cancer. NIH Publication 82-50179. Washington, DC: US Department of Health and Human Services (1982)

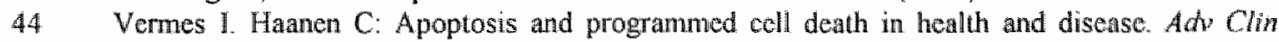
Chem 31:177-246 (1994).

45 Wijsman $J H$, Jonker $\mathbb{R R}$, Keijzer $R$, van de Velde $\mathrm{CJH}$, Comelisse CJ, van Dierendonck JH: A new method to detect apoptosis in paraffin sections: in situ condlabeling of fragmented DNA. $J$ Histochem Cylochem 41:7-12 (1993).

46 Wingo PA, Tong T, Bolden S: Cancer Statistics, 1995. CA Cancer J Clim 45:8-30 (1995).

47 The World Health Organization Histological Typing of Lung Tumors, 2nd edition. Am J Clm Parhol 77:123-136 (1982).

48 Wyllie AH, Kerr JFR, Curric AR: Cell death: the significance of apoptosis. Imt Rev Cytol $68: 251-306(1980)$. 



\title{
Clinical relevance of cell cycle
}

\author{
parameters in the lung
}




\section{Cytokinetic analysis of lung cancer by in vivo bromodeoxyuridine labeling}

Monique MFJ Tinnemans, Bert Schutte, Marie-Hélène JH Lenders,

Guul PM ten Velde, Frans CS Ramaekers and Geert H Blijham

Department of Molecular Cell Bialogr \& Genetics, University of Limburg; Department of Internal Medicine, Department of Pulmonology. University Hospital Maastricht; Department of Internal Medicine, University Hospital Utrecht.

Br J Cancer 67: 1217-1222 (1993) 


\section{Summary}

Cytokinetic parameters of various types of lung cancer were determined in bronchoscopy specimens after in vivo labeling with the thymidine analogue bromodeoxyuridine (BrdU). The S-phase fraction and BrdU labeling index were measured flow cytometrically, allowing calculation of the S-phase transit time and potential tumor doubling time. The methodology used was found to be feasible for obtaining cytokinetic data from $76 \%$ of the bronchial biopsy samples.

Despite the difference in clinical behavior and growth pattern between small cell lung cancer ( $\mathrm{SCLC}$ ) and non-small cell lung cancer (NSCLC), no significant differences were observed between the mean values of the cytokinetic parameters of SCLC and NSCLC. The estimated cell loss factor was higher in NSCLC than in SCLC.

It appears that the growth of a tumor, as clinically observed, is to a considerable extent influenced by cell loss. In accord with this assumption is the fact that we have observed non-BrdU labeled S-phase cel1s, both in tumor biopsies and in apparently normal tissue. The presence of these so-called unlabeled S-phase cells in relation to cell loss is discussed.

\section{Introduction}

Individual lung cancers differ in histological pattern and other phenotypic characteristics. These differences are relevant in predicting therapeutic responsiveness and prognosis?. In recent years it has become evidence that in lung cancer as well as in other types of malignancy, cell cycle parameters may be important prognosticators ${ }^{26}$. In several studies, a high S-phase fraction (SPF) was found to be associated with a shorter survival time $e^{27,30}$; this was also found for turnors other than lung carcinoma, including breast carcinoma ${ }^{12.17}$. In addition, a low ex vivo thymidine labeling index in patients with stage I NSCLC predicts for a longer survival time ${ }^{21}$.

Ex vivo labeling assays, as used in some of the studies described above, are sensitive to technical variability since they rely on the ex vivo continuation of DNA synthetic activity and on an efficient incorporation of the label. Also, measurements of SPF and ex vivo labeling index (LI) do not allow the estimation of dynamic cytokinetic parameters such as the $S$-phase transit time $\left(\mathrm{T}_{\mathrm{s}}\right)$ and the potential tumor doubling time $\left(\mathrm{T}_{\mathrm{put}}\right)$

A more accurate and comprehensive description of cytokinetic behavior is possible by in vivo labeling of tumor cells with the thymidine analogue bromodeoxyuridine (BrdU). If some time is allowed to elapse between pulse labeling and sampling, it is possible to determine cell kinetic properties over time from a single sample $e^{3,4}$. In this study, the feasibility of this methodology in the cytokinetic analysis of bronchoscopy 
specimens is described. The first results indicate that cell loss may play a more significant role in determining the growth tate of lung tumors than has been assumed so far.

\section{Materials and Methods}

\section{Patient material}

Patients selected for this study were suspected for endobronchial lung carcinoma and scheduled for bronchoscopy. After informed consent, the patients were infused with $50 \mathrm{mg} / \mathrm{m}^{2}$ BrdU (Janssen Pharmaceutica, Beerse, Belgium), dissolved in $100 \mathrm{ml} 0.9 \%$ $\mathrm{NaCl}$, within a timespan of $10 \mathrm{~min}$. The BrdU was given approximately 4 to 5 hours before bronchoscopy. Approval for the in wivo labeling method was given by the ethical committee of the University Hospital of Maastricht. Biopsies were taken with a flexible bronchoscope, fixed in formalin for routine diagnosis and in $70 \%$ ethamol for flow cytometric analysis. The latter samples were stored at $4^{\circ} \mathrm{C}$ until use.

\section{Flow cytometry and BrdU detection}

The biopsy specimens were double-stained with anti-BrdU (clone IIb $5^{11}$ ) and propidium iodide (PI), using the protocol described by Schutte et al. ${ }^{\text {I }}$. Briefly, ethanol fixed biopsies were minced in a petri dish and washed twice in phosphate buffered saline (PBS) pH 7.4, by centrifugation for $5 \mathrm{~min}$ at $400 \mathrm{~g}$. To obtain nuclei, the cell suspension was digested with $0.4 \mathrm{mg} / \mathrm{ml}$ pepsin (Boehringer Mannheim, Germany; 108057) in $0.1 \mathrm{~N} \mathrm{HCl}$ for $30 \mathrm{~min}$ at room temperature. Undigested fragments were then removed by sieving through a $50 \mu \mathrm{m}$ nylon mesh. After a washing step in PBS, the supernatant was removed and the pellet incubated in $2 \mathrm{ml} 2 \mathrm{~N} \mathrm{HCl}$, for 30 min at $37^{\circ} \mathrm{C}$. The nuclear suspension was then washed twice in Borax buffer $(0.1 \mathrm{M}$ sodiumtotraborate, $\mathrm{pH} 8.5$ ), and once in PBS containing $0.1 \%$ bovine serum albumin (BSA) and $0.1 \%$ sodium azide $\left(\mathrm{NaN}_{3}\right.$ ). The pelleted nucle were resuspended in $100 \mu$ monoclonal anti-BrdU antibody, appropriately diluted in PBS/BSA/NaN min at room temperature followed by two washing steps in PBS/BSA/NaN ${ }_{3}$. Primary antibody binding was visualized by incubating the pellet with $100 \mu$ l:20 diluted FITC-conjugated Fab fragments of rabbit anti-mouse IgG (DAKOPATTS, Glostrup, Denmark; F313) for 60 min at room temperature in the dark. After washing twice in $\mathrm{PBS} / \mathrm{BSA} / \mathrm{NaN}_{3}$, the nuclei were finally counterstained with $0.5 \mathrm{ml}$ of a $10 \mu \mathrm{g} / \mathrm{ml}$ propidium iodide (Calbiochem, La Jolla, CA; 537059) solution in PBS containing 0.1 $\mathrm{mg} / \mathrm{ml}$ RNase (Serva, Heidelberg, Germany). After incubation for at least $15 \mathrm{~min}$ in 
the dark, the samples were analyzed using the FACS IV flow cytometer (Becton Dickinson, Sunnyvale, CA). A total number of 5000 nuclei per sample was recorded.

\section{Calculation of cytokinetic parameters}

The DNA index (DI) was estimated from the single parameter DNA histograms. In case of one $G_{1}$ peak the sample was defined as diploid and the DNA index was considered 1.0 ; in case of two $G_{1}$ peaks the sample was defined as aneuploid and the DNA index was calculated by dividing the channel number of the right-sided peak to the channel number of the left-sided one, according to Hiddeman et al ${ }^{\$}$. The S-phase fraction (SPF) was determined from the DNA histogram using the rectangular fit method described by Baisch et al. ${ }^{1}$. To calculate the S-phase transit time $\left(\mathrm{T}_{\mathrm{z}}\right)$, the relative movement $(R M)$ of the labeled cells during the BrdU chase time $t$ ( = the time passed between administration of the BrdU pulse and fixation after bronchoscopy) was measured according to Begg et al. ${ }^{3}$.

In formula, the relative movement is defined by:

$$
R M=\frac{F_{L}-F_{G I}}{F_{a 1}-F_{G I}}
$$

where $F_{\mathrm{L}}$ is the mean DNA content of labeled undivided cells, and $F_{G 1}$ and $F_{G 2}$ the mean DNA contents of the $G_{1}$ and $G_{2}$-phase cells, respectively.

From the chase time $t$ and the relative movement, the S-phase transit time $\left(\mathbb{T}_{8}\right)$ can be estimated as follows:

$$
T_{*}=\frac{0.5}{R M-0.5} \cdot t
$$

Furthermore, on basis of these parameters the potential doubling time $\left(T_{\text {pot }}\right)$ of the tumor can be defined according to White et all..$^{32}$ as:

$$
T_{p o t} \ln 2 \cdot \frac{T}{v}
$$

with

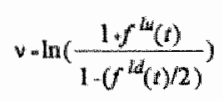


and with fu being the fraction labeled undivided cells, and fid being the fraction labeled divided cells.

The labeling index (LD) was defined as the percentage of BrdU positive cells. No corrections were made for labeled cells in $\mathrm{G}_{1}$ that had undergone cell division in the period between administration of the BrdU and sampling of the biopsy.

\section{Results}

Fifty patients entered the study (42 male, 8 female; median age 68, range 44-82). Full analysis was possible in 38 cases; in 12 patients DNA analysis could be perfomed but the labeling results were of too poor quality to allow conclusions. Of the patients with malignant disease the expected one-quarter of the patients had small cell lung cancer, and around three-quarter of these patients had disease limited to the thorax (Table I).

Table I. Final diagnosis and stage of disease of patients with lung cancer

\begin{tabular}{lllllllll}
\hline diagnosis & $n$ & LD & ED & I & II & llil & IV & unknown \\
SCLC & $12(9)^{11}$ & 8 & 4 & & & & & 0 \\
SQCC & $14(10)$ & & & 3 & 3 & 4 & 3 & 1 \\
AC & $8(5)$ & & & & 1 & 1 & 6 & 0 \\
LCLC & $12(8)$ & & & 1 & & 6 & 2 & 3 \\
not malignant & $4(4)$ & & & & & & & \\
\hline
\end{tabular}

"Hetween brackets the number of patients with this dignosis in the biopsy used for cytokinetic analysis. A tof al number of 14 biopsies from patients with lung cancer was histologically tumor-negative.

SCLC: small cell lung carcinoma; SQCC: squamous cell carcinoma; $A C$ : admociarcinoma; LCLC: Iarge ad lung carcinoma: $\mathrm{LD}$ : limited disease; $\mathrm{ED}$ : extensive disease; lwV: staging according to UICC crteria

Ploidy characteristics are given in Table II. Of all biopsies that contained malignant cells $(\mathrm{n}=32), 38 \%$ appeared to contain an aneuploid stemline; the median relative size of the aneuploid population in these samples was $21 \%$. In only 1 of 14 histologically tumor-negative biopsies from patients with lung cancer, an aneuploid population could be detected.

For the cytokinetic analysis we divided the 38 fully evaluable patients into three groups: no malignant disease $(n=2)$, histologically tumor-negative biopsies from patients with malignant disease $(n=9)$ and biopsies containing malignant cells, 
including the one biopsy that was histologically negative but contained aneuploidy (n=27). Data on S-phase fractions as calculated from the univariate DNA histogram, labeling index with BrdU as calculated from the univariate BrdU-fluorescence analysis and the duration of S-phase and the potential doubling time as calculated

Table II. Ploily characteristics of bronchoscopy specimens

\begin{tabular}{ll}
\hline & Aneuploid \\
No malignancy & $0 / 4$ \\
Non malignant biopsy from & $1 / 14$ \\
patients with malignancy & \\
All malignant biopsies & $12 / 32$ \\
SCLC & $1 / 9$ \\
SQCC & $16 / 10$ \\
AC & $1 / 5$ \\
LCLC & $4 / 8$ \\
\hline
\end{tabular}

SCLC: smatl cell lung carcinoma; SQCC: squamous cell carcinoma; AC: adenacarcinoma; LCLC Harge cell hing carcinoma

Table III. Cytokinetic characteristics of bronchoscopy specimens

\begin{tabular}{|c|c|c|c|c|c|c|}
\hline & $n$ & $\begin{array}{l}\text { SPF (\%) } \\
\text { mean (lange) }\end{array}$ & $\begin{array}{l}\text { LI (\%) } \\
\text { mean (range) }\end{array}$ & $\begin{array}{l}\text { Ts ihy } \\
\text { mean (tange) }\end{array}$ & $\begin{array}{l}\text { Tpot (h) } \\
\text { mear (range) }\end{array}$ & $\begin{array}{l}\text { USPF }(\%) \\
\text { method } 1 / \text { method } 2 \\
\text { mean (range) }\end{array}$ \\
\hline NM & 2 & $9.0(949)$ & $3.6(1.1-6.1)$ & $9.9(7.7-12.0)$ & $422(113-730)$ & $74(61-87) / 82(71-92)$ \\
\hline NMDM & 9 & $8.4(5-12)$ & $2.7(1.2-7) .8)$ & $11,4(4,2-41,1)$ & $414(156-767)$ & $68(33-89) / 85(74-98)$ \\
\hline$M^{*}$ & 27 & $16.4(6-44)$ & $9.9^{21}(1.1-33.6)$ & $10.0(3.6-29.4)$ & $187^{2:}(36-670)$ & $50^{2}(19-81) \sqrt{7} 0^{21}(36-99)$ \\
\hline SCLC & 7 & $11.6(6-22)$ & $7.0(1.1=17.6)$ & $9.0(4.5-13.5)$ & $207(73-670)$ & $50(21-81) / 67(4-1-81)$ \\
\hline SQCO & 10 & $23.1(8 \div 44)$ & $12.1(3.8-39.6)$ & $123(40-19.4)$ & $71(45-498)$ & $51(24-89) / 70(36-99)$ \\
\hline$A C$ & 3 & $42.0(\theta-19)$ & $11.7(1.2+21.9)$ & $0.4(5.1-7.8)^{\circ}$ & $205(36-533)$ & $4 B(19-81) / 80(65-95)$ \\
\hline LOLG & 7 & $1.6 .1(7-24)$ & $8.2 \quad(1.3-10.4)$ & $10.6(3.6-29.4)$ & $223(45-571)$ & $55(22-91) / 73(54-86)$ \\
\hline
\end{tabular}

Including one biopsy that was histologicaily noimal but contained aneuploid cells.

"Significanty different trom the wo other categories of patients in a Student's I test.

NM: non-malignant biopsies; NMDM: non-malignant diploid biopsies from patients with malignancy" M: all malignant biapsies: $5 G L C$; small celll lung carcinoma; $\$ Q C C$; squamous cell carcinoma; $A C$ : adenocarcinoma; LCLC: large cell

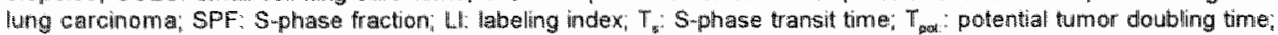
USPF: untabeded Sphise fraction 
from the bivariate analysis are given in Table III. Between biopsies with no malignanoy and non-malignant biopsies from patients with malignancy, no differences were observed.

Malignant biopsies showed a higher SPF (n.s.), a significantly higher LI ( $P=0.01$ ), equal $T_{s}$ and significantly shorter potential doubling time $(P=0.0014)$.

Within the group of malignant biopsies no differences were observed; in particular, the mean potential doubling time of SCLC was 207 hours, which is not significantly different from the nean $T_{\text {pat }}$ of 194 hours for NSCLC.

We next compared the cytokinetic characteristics for diploid and aneuploid tumors and included also the group of lung cancer patients with nonmalignant, diploid biopsies (Table [V). The potential doubling time appears to decrease in the order of non-malignant tissue, diploid tumors and aneuploid tumors. This occurred despite the fact that aneuploid tumors had a longer S-phase transit time and therefore can only be explained by their high labeling index. In all samples the SPF appeared to exceed the LI to a considerable extent. We therefore investigated whether these two potential parameters of S-phase activity are indeed interrelated. In Figure 1 the comelation between LI and SPF is given for all samples with full analysis $(n=38)$. The two parameters correlated significantly $(r=0.77)$, but at the level of individual samples the SPF almost always exceeded the LI. This suggests the presence of a considerable number of cells with S-phase DNA content without the ability to incorporate BrdU, we called these cells 'unlabeled S-phase cells'. The presence of unlabeled S-phase cells could be a tumor characteristic with prognostic or therapeutic implications. An example of the presence of a considerable population of cells with S-phase DNA content but without incorporated BrdU is given in Figure 2.

Table IV. Cytokinetic characteristics of patients with malignancy in relation lo ploidy status

\begin{tabular}{|c|c|c|c|c|c|}
\hline & $n$ & $\begin{array}{l}\text { SPF } \\
\text { mean (range) }\end{array}$ & $\begin{array}{l}\text { Ll } \\
\text { mean (range) }\end{array}$ & $\begin{array}{l}\text { Ts } \\
\text { mean (range) }\end{array}$ & $\begin{array}{l}\text { Tpot } \\
\text { mean (range) }\end{array}$ \\
\hline $\begin{array}{l}\text { Won malignant diploid } \\
\text { biopsy from patien ss } \\
\text { with mallignancy }\end{array}$ & 9 & $8.4(5-12)$ & $2.7(1.2-7.8)$ & $11.1(4.2 \sim 41.1)$ & $414 "(156-767)$ \\
\hline Diptoid tumours & 14 & $9.4(6-17)$ & $5.0(1.911 .9)$ & $6.9(3.6 \cdot 13.5)$ & $232(45-670)$ \\
\hline Aneuploid tumours & 13 & $25.3^{17}(14-44)$ & $14.7^{\text {th }}(3.8-336)$ & $14.0^{2}(5.7-29.4)$ & $161(36-490)$ \\
\hline
\end{tabular}

1) Significantly different from the wo other categories of pattients in a Studeril's thest.

2) Significantly different from the group of diploid tumours in a Student"s it test.

SPF: S-phase fraction; LI: labeling index; $T_{0}$ : Saphase transit time; $T_{\text {wot }}$ potential tumor doubling time 


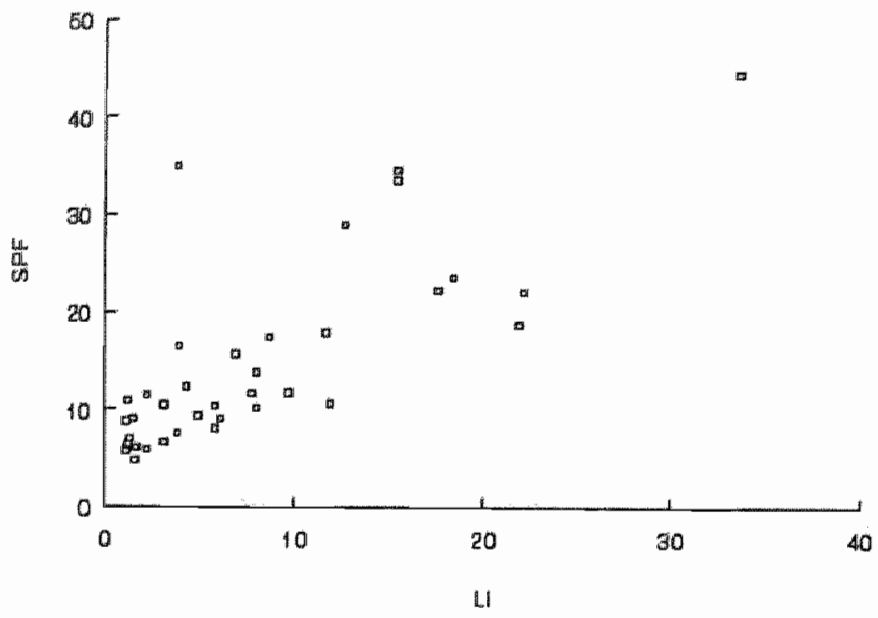

Figure 1. Correlation between percentage BrdU positive cells (labeling index: $\mathrm{Ll}$ ) and S-phase fraction (SPF) for all patients with full analysis $(n=38)$. Correlation coefficient $r=0.77$.

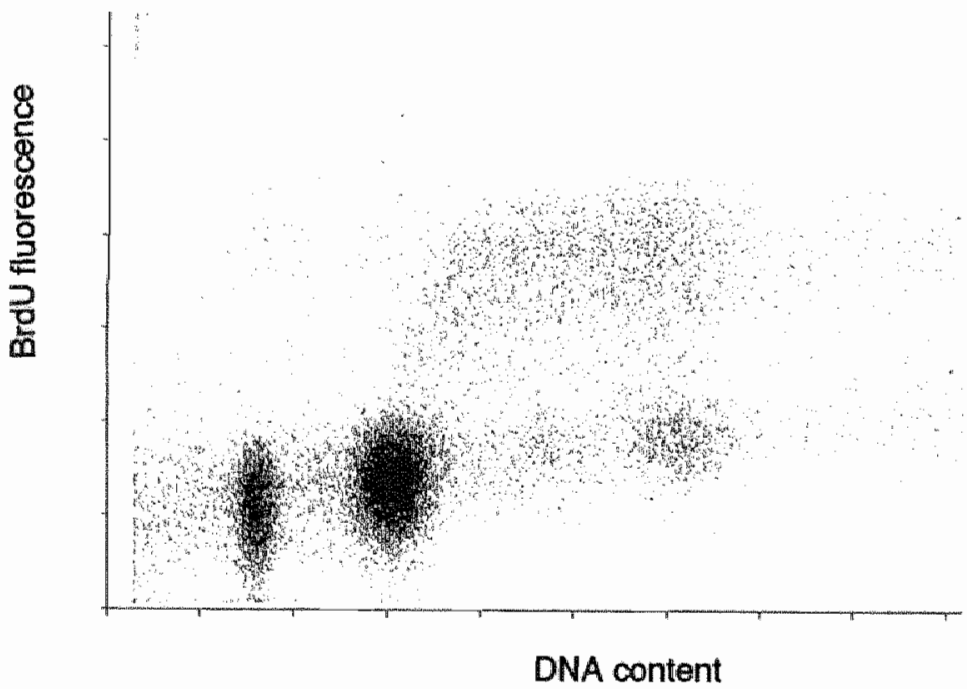

Figure 2. Aneuploid tumor biopsy sample. $X$-axis: DNA content; $Y$ maxis: BrdU fluorescence. 
We developed methodologies to quantify their frequency by determining an 'unlabeled S-phase fraction' or USPF, indicating the fraction of all cells with S-phase DNA content that do not label. This was done using the following formula:

$\mathrm{USPF}=(\mathrm{SPF}-\mathrm{LI}) / \mathrm{SPF}$. This formula was applied to the population at large (method 1) or to a representative portion of the population by restricting the analysis to a small segment in the second part of the S-phase (method 2). The latter method avoids the possible disturbing effect of cells that are unlabeled because they entered the $S$-phase in the time period between in vivo labeling and bronchoscopy.

Results of the two methods are given in Table III. It appears that the two methods to estimate the USPF are different in that method 2 gives higher estimates. However, in the 3 groups of patients the results of the two methods show a similar tendency; the correlation coefficient was found to be $0.7(P=5.9 \mathrm{E}-5)$. Whatever method used, the USPF appears to be lower in malignant samples $(P=0.01$ (method 1 ) or $P=0.0064$ $(\operatorname{method} 2)$ ).

\section{Discussion}

The main goal of this study was to investigate the feasibility of determining cytokinetic characteristics from human bronchoscopy specimens. Therefore we entered a heterogeneous group of patients encompassing the full spectrum of types and stages of bronchial carcinoma as well as biopsies of normal bronchial tissue. Fifty of such specimens were adequate to the extent that patients were eligible and a nuclear suspension of good enough quality for flow cytometric analysis was obtained. Full analysis was possible in $76 \%$ of all cases. The main reasons for not being able to perform cytokinetic analysis was the failure to detect a coherent cohort of labeled cells. In these samples very few cells (less than $1 \%$ ) were found labeled with BrdU and these cells were randomly scattered over the dotplot. This occurred in $6 / 17$ nonmalignant and in 6/33 malignant specimens, indicating that successful analysis is possible in an even higher percentage of patients with malignant tumors. Acute sideeffects were not observed with the dose of BrdU employed, as has also been the case in earlier studies with this dose and slightly higher doses $s^{6,10,11,14,16,20,28,34}$.

During the course of this study, some problems have arisen concerning flow cytometric analysis. Difficulties in discerning the tumor cell population from other cell types present in the bronchoscopy sample were manifest in particular in diploid samples, where it is not possible to make a distinction between normal cells or tumor cells with a diploid DNA content. In aneuploid samples, the major problem was overlap of diploid and aneuploid populations. An additional disturbing effect was generated by the accumulation of cell debris in the sample. This makes estimations of cell numbers in various phases of the cell cycle less reliable. In order to avoid the problems mentioned above, we started to investigate the use of dual parameter image 
cytometry as an alternative. This technique is currently being optimized. Begg et al. ${ }^{2}$ recently described three-color fluorescence flow cytometry as a method for selecting the desired malignant cell population for kinetic analysis, that also may be useful in this respect.

One of the most striking results of this study is the finding of a considerable number of cells with a DNA content between $\mathrm{G}_{1}$ and $\mathrm{G}_{2}$ that do not take up BrdU: the socalled unlabeled $S$-phase cells. These cells were observed in virtually each sample. Previously, the existence of this phenomenon had also been described by Darzynkiewicz, Forster et al. ${ }^{6}$, Ten Velde et al. ${ }^{28.29}$ and Wilson et al. ${ }^{3.4}$, while an exceeding of the SPF over the LI was reported by Meyer \& Coplin ${ }^{13}$; Teodori et all. ${ }^{25}$ and Wilson et al. ${ }^{33}$. We were concerned about technical artefacts and therefore determined the frequency of such cells (USPF) by restricting the analysis to a window close to the $\mathrm{G}_{2} / \mathrm{M}$ peak. This eliminates the contribution of cells that have entered the S-phase in the time between labeling with BrdU and sampling of the biopsy, and would also possibly decrease the influence of debris. Still, we found that $36-99 \%$ of the S-phase cells was unlabeled. In interpreting these data it has to be taken into account, however, that cell debris may still interfere with the estimation of the USPF, in particular in diploid samples with a relatively low frequency of labeled cells. This is due to the fact that cell debris shows an exponential decline with relatively higher counts in the lower DNA channels. This may in part explain why normal tissues with a low LI were found to have a higher USPF as compared to malignant biopsies.

The cause of S-phase cells not to incorporate the DNA precursor BrdU can be 2-fold: either the cells are cycling but the BrdU cannot reach them or the BrdU is present but the cells do not cycle. The first possibility implies dose-related problems. In a study with human bone marrow, Hupperets et al." investigated the feasibility of in vivo labeling of bone marrow cells with BrdU in doses varying from $700 \mathrm{mg} / \mathrm{m}^{2}$ to 50 $\mathrm{mg} / \mathrm{m}^{2}$. They found that in vivo labeling with $50 \mathrm{mg} / \mathrm{m}^{2}$ BrdU was safe, feasible and as effective as higher doses. Furthermore, if dose was an issue, one would expect to find cells with a labeling intensity varying between negative and maximally positive rather than two distinct populations with clearly negative and positive characteristics, as we observed and as is illustrated in Figure 2. Finally, Forster et $\mathrm{al}^{6}$, using a higher dose of BrdU in a study of squamous head and neck cancer, reported similar labeling indices as well as the presence of unlabeled S-phase cells.

Morstyn et al. "found a uniform BrdU distribution in small melanoma but a heterogeneous distribution of BrdU in large melanoma which they ascribed to differences in perfusion. This points to the possibility that the presence of unlabeled S-phase cells is related to local dose problems, due to the presence of areas with poor perfusion. In that case, one would expect the cells that do label to pass through the S-phase with a constant rate. In contrast, we found variable durations of S-phase with some biopsies showing extremely long S-phase transit times. It cannot be ruled out, however, that at least part of the S-phase cells do not label because of poor availability of BrdU. 
A second possibility to explain the presence of unlabeled S-phase cells could be that cells, for some reason, stop cycling during S-phase. Assuming that this is a random event, this would imply that cells in the BrdU labeled population will arrest also. According to the theoretical model developed by White ${ }^{31}$, this will result in high values for $T_{s}$. Therefore, the length of the S-phase transit time could be another indicator for the presence of unlabeled S-phase cells. From the data presented in Table III, it appears that although the mean S-phase transit time did not differ between the various groups, there always was a wide range with some samples showing very long $T_{\mathrm{s}}$. It remains to be determined whether the duration of $S$-phase could be a better indicator for the occurrence of cell arrest in S-phase than the fraction of unlabeled Sphase cells, in particular in case of a poor ratio between the degree of labeling and the presence of debris. The background and clinical implications of unlabeled S-phase cells are currently being investigated by performing in witro experiments subjecting tumor cells to poor metabolic states.

When comparing various groups of samples, we found significant differences in SPF, LI and potentiall doubling time between malignant and non-malignant biopsies. Within the various types of lung cancer, cytokinetic parameters did not differ. Similarly, no significant differences were observed between the two major groups of lung cancer; small cell lung cancer (SCLC) and non small cell lung cancer (NSCLC). In particular, potential doubling times did not differ (SCLC: 8.6 days; NSCLC: 8.1 days), whereas small cell lung tumors are known to be clinically more agressive and appear to double their cell number at a higher rate than do cancers of the non small cell type. This points to the possibility that the cell loss factor is considerably higher in non small cell lung cancer than in small cell lung cancer. The mean tumor volume doubling times for these types of lung cancer are approximately 3 months (100 days) for NSCLC and 1 month ( 30 days) for $\mathrm{SCLC}^{19}$. Our cytokinetic data however, indicate a doubling of the cell number in 8.1 days (NSCLC) and 8.6 days (SCLC). Wilson et al ${ }^{3.4}$, who calculated the potential tumor doubling time in 25 solid human tumors, found an overall mean of only 5.5 days. A significant discrepancy between the calculated tumor doubling time and the measured doubling time was also reported by Terz et al. ${ }^{24}$. The cell loss factor can be defined as $\left(1-\left(\mathrm{T}_{\text {por }} / \mathrm{T}_{\mathrm{d}}\right)\right) \times 100 \% \%^{23}$, where $T_{\text {pot }}$ is the potential doubling time (assuming there is no cell loss) and $\mathrm{T}_{\mathrm{d}}$ is the actual doubling time. Using this formula and our data, the cell loss factor in NSCLC is estimated as to be $90 \%$, whereas the cell لloss in SCLC is estimated on $70 \%$. This is in accord with one previous report, in which the cell loss of human tumors was found to range from $40 \%$ to $80 \%$, with a higher cell loss in squamous cell lung carcinoma than in small cell lung carcinoma $^{20}$, 1991). Taken together, our data strongly support the concept that the relatively slow growth rate of NSCLC as compared to SCLC does not depend on differences in proliferation but rather on the rate of cell loss. Reports in the literature, concerning Ki67 expression, show no significant differences between SCLC and NSCLC, although there seems to be a trend towards a higher positive Ki67 fraction in $\mathrm{SCLC}^{822}$. This is not in conflict with our hypothesis that SCLC exhibit a lower cell 
loss factor than NSCLC, since Ki67 is a protein which is expressed in proliferating cells. However, it is a static marker which does not reflect active proliferation and which therefore cannot be compared to the cytokinetic parameters measured in this studly.

We have demonstrated the feasibility to obtain dynamic cytokinetic data from bronchoscopy specimens after in vivo labeling with BrdU in a majority of patients presenting with lung cancer. Growth parameters such as the potential tumor doubling time, the S-phase transit time and an estimation of the presence of arrested S-phase cells can be obtained that will now be assessed for their prognostic and therapeutic implications.

\section{Acknowledgements}

This study was supported by a grant from the Dutch Cancer Society (grant no. IKL-90-01). 


\section{References}

1 Baisch $H$, Beck $H$, Christensen I, Hartmannn N, Fried J, Dean P, Gray I, Jett J, Johnston D, White $R$, Nicolini C, Zietz S, Watson J: A comparison of mathematical methods for the analysis of DNA histograms obiained by flow cytometry. Cell Tissue Kinet 15:235-249 (1982).

2 Begg $\mathrm{AC}$, Hofland 1: Cell kinetic analysis of mixed populations using threc-color fluorescence flow cytometry. Cyomery 12:445-454(1991).

3 Begg AC, McNally NI, Schrieve DC, Karchner H: A method to measure the duration of DNA synthesis and the potential doubling time from a single sample. Cytometry 6:620-626 (1985).

4 Carlton JC, Terry NHA, White RA: Measuring potential doubling times of murine tumors using flow cytomeiry. Cytometry 12:645-650 (1991).

5 Darzynkiewicz Z: Cytochemical probes of cycling and quiescent cells applicable to flow cytometry. In Techmiques in Cell Cycle Analysis, Gray JE, Darzynkicwic Z (eds), pp 255-290. Humana Press, Inc: Clifton, New Yersey (1986).

6 Forster G, Cooke TG, Cooke LD, Stanton PD, Bowic G, Stcll PM: Tumor growth rates in squamous carcinoma of the head and neck measured by in vivo bromodcoxyuridinc incorporation and flow cytometry. BrJ Cancer 65:698-702 (1992).

7 Fraire A.E, Johnson EH, Yesner R, Zhang XB, Spjut HJ, Greenberg SD: Progmostic significance of histopathologic subtype and stage in small cell lung cancer. Human Pathol 23:520-528 (1992)

8 Gatter $\mathrm{KC}$, Dunnill MS, Gerdes J, Stein H, Mason. DY: New approach to assessing lang tumours in man. $J$ Clin Pathol 39:590-593 (1986).

9 Hiddeman W, Schumann J, Andreefr M, Barlogic B, Herman CJ, Leir RC, Mayall BH, Murphy RF, Sandberg AA: Convention on nomenclature for DNA cytometry. Cyrometry 5:445-446 (1984).

10 Hoshino T, Nagashima $T$, Murovic J, Levin EM, Levin VA, Rupp SM: Cell kinctic studies of in situ human brain tumors with bromodeoxyuridine. Cytometry 6:627-632 (1985).

11 Hupperets PSJG, Schutte B, Van Assche C, Reijnders MMJ, Blijhan GH: Proliferative characteristics of human bone marrow cells following in viwo administration of bromodeoxyuridine. Cancer Chemother Pharmacol 18; suppl.1: 148 (1986).

12 Kallioniemi OP, Hietanen $T$, Mattila $J$, Lehtinen M, Lauslahti $K$, Koivula T: Ancuploid DNA content and high $\mathrm{S}$ phase fracion of tumour cells arc related to poor prognosis in paticnis with prinary breast cancer. Eur J Cancer Clin Oncol 23:277 (1986).

13 Meyer JS, Coplin MD: Thymidine labeling index, flow cytometric S-phase measurement, and DNA index in human tumors. Am J Clm Pah 89.586-595 (1988)

14 Miller MA, Mazewski CM, YousuC N, Sheikh Y, While LM, Yanik GA, Hyamis DM, Lampkin $B C$, Raza A: Simultaneous immunohistochemical detection of IUdR and BrdU infused intravenously to cancer patients. JHistochem Cyochem 39:407-412 (1991).

15. Morstyn $G_{*}$ Hsu S-M, Kinsella $T$, Gratznen H, Russo A, Mitchell JB: Bromodeoxyuridinc in tumors and chromosomes detceted with a monoclonal antibody.

$J$ C I in Invest 72:1844-1850(1983).

16 Nagashima T, Hoshino T, Cho KG, Edwards MSB, Hudgins RU, Davis RL: The proliferative potential of human ependymomas measured by in situ bromodeoxyuridine labeling. Cancer 61:2433-2438(1988)

17 O'Reily SM, Camplejohn RS, Barnes DM, Millis RR, Allen D, Rubens RD, Richards MA. DNA index, S-phase fraction, histological grade and prognosis in breast cancer. Br.J Cancer 61:671. $674(1990)$. 
18 Schuthe B, Reinders MMJ, Wan Assche CLMVJ, Hupperets PSIG, Bosman FT, Blijham GH: An improved method for the immunocytochemical detecion of bromodeoxyuridine labeled nuclei using flow cylometry. Cylometry 8:372-376 (1987).

19 Selawry OS, Hansen HH: Respiratory tract cancer In Cancer Medicine, Holland JF, Frei E (eds). pp 1732. Loa ic Febiger: Philadelphía (1982).

20 Shmomatsuya $T$, Tanigawa $N$, Muraoka $R$ : Proliferative activity of human tumors: assessment using bromodcoxyuridine and flow cytometry. Jpm J Cancer Res 82:357.362 (1991).

21 Silvestrini $R$, Muscolino $G$, Costa A, Lequaglie $C$, Veneroni $\$$, Mezzanotie $G$, Ravasi $G$ : Could cell kinctics be a predictor of prognosis in non-small cell hing cancer? Lung cancer $7: 165-170$ (1991).

22 Soomiroo $\mathrm{N}$, Whimster WF: Growh fraction in lung tumours determined by Ki67 inmunostatning and comparison with AgNOR scores. J Pathol 162217 7-222 (1990).

23 Steel GG: Growth kimetics of fonours, pp.70.72. Clarendon Press: Oxford (1977).

24 Terz J., Curuched HP, Lawrence W: Analysis of the cell kinetics of human solid tumors. Cancer $5: 1100 \cdot 1110(1971)$

25 Teodori L, Trinca ML, Gochde W, Hemmer J, Salwat E, Stomiello G, Mauro F. Cytokinetic investigation of lung tumors using the anti-bromodeoxyuridine (BUdR) monoclonal antibody method: comparison with DNA flow cytometric data. Int J. Cancer 45:995-1001 (1990).

26 Tubiana $M$, Courdi $A$ : Cell proliferation kinetics in human solid tumors: relation to probability of metastatie disscmination and long-term survival. Radiother Oncol 15:1-18 (1989).

27 Ten Velde GPM, Schutte B, Vermeulen A. Volovics A, Rejnders MMJ, Blijham GF Flowcytometric analysis of DNA ploidy level in parafin embedded tissue of non-small lung cancer. Eur $J$ Center Clin Oncol 24:455-460 (1988).

28 Ten Velde GPM: Cylokinetic analysis of lung cancer specimens by in vivo bromodeoxyuridine labeling. In Thesis pp. 85-94. University of Limburg: Maastriclat. The Netherlands (1989a).

29 Ten Volde GPM, Schutte B, Rejinders MMJ, Bosman FT, Bligham GH: Cytokinetic analysis of lung cancer by bromodeoxyuridine labeling of cylology specimens. Cyometry 10:807-810 $(19896)$.

30 Volm M, Matterns J, Sonka J, Vogt-Schaden M, Wayss K: DNA distribution in non-small-cell lung carcinomas and its relationship to clinical behavior. Cytometry 6:348-356 (1985).

31 White RA: A theory for analysis of cell populations with non-cycling $\mathrm{S}$ phase cells. It Theor Biol $1502201-214(1991)$.

32 White RA, Terry NHA, Meistrich ML, Calkins DP: Improved method for computing potential doubling time from flow cytometric data. Cytometry 11:314-317(1990).

33 Wilson GD, McNally NJ, Dunphy E, Karcher H, Pfragner R: The labelling index of human and mouse tumours assessed by bromodeoxyuridine staming in vitro and in viwo and llow cytonctry. Cyromespy $6.64:-647$ (1985).

34. Wilson GD. McNally NJ, Dische S, Saunders MI, Des Rochers C, Lewis AA, Bennet MH: Messurement of cell kinetics in human tumours in vivo using bromodeoxyuridine incorporation and now cylometry, BrJ Cancer $58.423-431$ (1988). 


\title{
Prognostic value of cytokinetic parameters in lung cancer after in vivo bromodeoxyuridine labeling
}

\author{
Monique MFJ Tinnemans, Marie-Hélène JH Lenders, Guul PM ten Velde, \\ Geert H Blijham, Frans CS Ramaekers and Bert Schutte
}

Dept. of Molecular Cell Biology \& Genetics, University of Limburg. Departments of internal Medicine and Putmonology. University Hospital Maastricht; Department of Interral Medicine. University Hospital Uirecht. 


\section{Summary}

To improve the overall survival rate in lung cancer by adjustment of treatment protocols on basis of tumor characteristics of individual patients, independent predictive parameters are required. Therefore, we evaluated the prognostic value of cytokinetic parameters such as bromodeoxyuridine (BrdU) labeling index (LD), Sphase fraction (SPF), unlabeled S-phase fraction (USPF), S-phase duration ( $\mathrm{T}_{5}$ ) and potential tumor doubling time ( $\left.T_{\text {pot }}\right)$, next to more established parameters.

To this end, a series of 92 bronchoscopic specimens of in vivo BrdU labeled lung cancer patients, 72 presenting with non-small cell lung carcinoma (NSCLC) and 20 patients with small cell lung carcinoma (SCLC), were analyzed flow cytometrically. Clinical as well as cytokinetic data were collected and related to survival times over a follow-up period of 2 to 7 years.

We found that $T_{\text {pot }}$ was a significant independent discriminator of good and poor prognosis in NSCLC. In particular, in non-squamous NSCLC a short $T_{\text {pot }}$ short $T_{\mathrm{s}}$ and high LI predicted for shorter survival time. In squamous cell carcinoma, a high USPF may predict a shorter survival period, although the correlation was only borderlinesignificant. We conclude that these parameters may in future be of use in drawing up more adequate treatment schedules for lung cancer.

\section{Introduction}

Lung cancer is one of the most important public health problems throughout the world. Only a marginal gain in the 5-year survival rate of these cancers has been achieved over the past two decades, despite improved therapeutic schedules ${ }^{27}$. As described by Melamed et all. ${ }^{23}$, the majority of the patients $(>60 \%)$ present to the physician in the late phase of their disease. In order to improve patient survival. methods for earlier detection and more specific treatment protocols are needed. This latter approach requires reliable prognostic indicators.

For lung cencer it has been established that prognosis is influenced by the stage or extent of the disease at presentation ${ }^{12,38}$, histologic tumor type ${ }^{16,38}$, tumor size and location $^{36,17}$ and performance status ${ }^{12,16}$. The prognostic potential of these factors often becomes only evident from studies with large patient populations and therefore these parameters are not conclusive for the prognosis of individual cases. Since the behavior of each individual tumor is determined by a complexity of clinical features, as well as by the intrinsic growth potential of the malignancy, survival studies aim at the integration of such parameters ${ }^{37}$.

The growth of a tumor can be defined as the result of cell prollferation and cell loss. It is hypothesized that a high proliferative activity in a large proportion of the tumor 
cells is associated with a poor prognosis of patients with a malignancy ${ }^{11,24,45,47}$. Cell proliferation is in general measured by determining the number of cells that are actively taking part in the cell cycle, and the rate at which the various phases of the cell cycle are traversed. Several authors have published evidence for an independent prognostic value of proliferation parameters in non-small cell lung carcinoma ${ }^{38,46,48}$. In the past years, various methods have been developed to quantitate cell proliferation in tissue sections or in single cell preparations. Established procedures such as mitotic figure counting and detection of DNA synthesis by $\left[{ }^{3} \mathrm{H}\right]$-thymidine incorporation, however, display important shortcomings with regard to reproducibility and performance in a clinical setting ${ }^{31}$. On the other hand, intrinsic cellular proteins such as Proliferating Cell Nuclear Antigen (PCNA) and Ki67-antigen have been described to be useful. markers for measuring cell proliferation in various types of tissues, $7,1,19$. In particular Ki67-antigen expression was found to be a good indicator of patient survival time $^{30,45}$. However, both PCNA and Ki67-antigen detect a static situation rather than reflecting active proliferative behavior of the tumor. Dynamic kinetic parameters, such as S-phase duration $\left(\mathrm{T}_{\mathrm{s}}\right)$ and potential doubling time $\left(\mathrm{T}_{\mathrm{pot}}\right)$, may provide a more representative estimation of a tumor's proliferative state. Next to the cytokinetic parameters, DNA aneuploidy was described to be a significant determinant for shorter survival in various solid tumors ${ }^{2,10,11,26}$. Aneuploid tumors have been reported to display a signifantly higher $\mathrm{LI}$ and SPF as well as a shorter $\mathrm{T}_{\text {por }}$ than diploid tumors ${ }^{14,25,36}$.

An accurate and feasible method to obtain cytokinetic information using in vivo labeling with the thymidine analogue BrdU was described in a previous paper ${ }^{40}$. In the present study, a larger series of bronchoscopic specimens of in vivo BrdU labeled lung cancer patients was flow cytometrically analyzed and cell cycle parameters as well as clinical parameters were related to patient survival during a follow-up period of 2 to 7 years.

\section{Materials and Methods}

\section{Patient material and sample preparation}

The series of biopsy samples analyzed in the previous chapter $(n=35)$ was extended with 57 cases.

Samples were prepared for bivariate flow cytometric BrdU/DNA detection according to the protocol described in chapter 2 . 


\section{Flow cytometric analyses}

The first series of samples ${ }^{40}$ was analyzed using a FACS IV flow cytometer (Becton Dickinson, Sunnyvale, CA), whereas the second series was analyzed on a FACSort (Becton Dickinson). Both flow cytometers were equiped with single Argon ion lasers, tuned to $488 \mathrm{~nm}$. Emission filters used were 515-545 BP (green) and 600 LP (red). A minimum of 5000 nuelei per sample were recorded and data were stored in list mode. FITC signals were recorded as logarithmic amplified data, while PI signals were recorded as linear amplified data. No compensation was used. The second series of data was analyzed with the standard Lysis and Cellfit software (Becton Dickinson), and data were gated on pulse processed PI signals to exlude doublets and larger aggregates. Samples where no analysis was possible due to extensive debris were excluded from the study.

\section{Calculation of cytokinetic parameters}

The DNA index (DI), S-phase fraction (SPF), labeling index (LI), S-phase transit time $\left(\mathrm{T}_{\mathrm{s}}\right)$ and potential tumor doubling time $\left(\mathrm{T}_{p o s}\right)$ were calculated as was described in chapter 2. The unlabeled S-phase fraction (USPF), i.e. the fraction of BrdU negative S-phase cells, was expressed as a percentage of the total cell population.

\section{Survival curves and statistical analysis}

The two series of analyses (i.e. either performed on the FACS IV or on the FACSORT) were combined, since the impact of doublets and debris on the calculated parameters was negligible. The two main categories of lung cancers, i.e. small cell lung cancer (SCLC) and non-small cell lung cancer (NSCLC), were analyzed separately. In order to construct survival curves, for each cytokinetic parameter the cases were classified higher/equal or lower than the median value of of their own analysis group (i.e. FACS IV or FACSORT) and category. Contingency tables were constructed for each cytokinetic parameter versus stage of disease and versus tumor histology. A chisquare test was used to determine whether these parameters were related.

In addition to the cytokinetic variables, also stage, gender, age (younger or older than 65 years), type of NSCLC (squamous/non-squamous) and DNA ploidy (diploid or aneuploid) were analyzed. Survival curves were estimated using the Kaplan-Meier tmethod $^{21}$, with the cut-off point determined at five remaining cases ${ }^{1}$. A logrank test was used to examine the differences in survival curves. No multivariate analysis was performed for the separate categories of lung cancer due to the relatively small numbers of patients with complete data sets. 


\section{Results}

A total number of 130 patients entered the study. Seventy-one percent of the cases $(n=92)$ gave evaluable flow cytometric data and conld be included in the study. Of the twenty-nine percent drop-out cases, five percent exhibited a non-malignant disease. The remaining cases were not included due to irrelevant type of disease, too short or too long BrdU chase time, treatment prior to biopsy or random BrdU labeling patterns due to extensive debris.

The characteristics of the 92 cases included in the analysis are given in Table I. Twenty-two percent had SCLC and $78 \%$ NSCLC. Aneuploidy was found in $29 \%$ of all biopsies ( $33 \%$ in NSCLC, $15 \%$ in SCLC). Similar to the first series of samples ${ }^{40}$, no differences were found between SCLC and NSCLC for the mean values of LI, $T_{3 x}$ $T_{\text {pol }}$ USPF and SPF in the second series of samples (data not shown).

Table I. Patient tumor characteristics.

\begin{tabular}{|c|c|c|}
\hline & & Number of patients $(\%)$ \\
\hline Age & $\begin{array}{l}\$ 65 \text { years } \\
>65 \text { years } \\
\text { unknown }\end{array}$ & $\begin{array}{rr}39 & (42) \\
47 & (51) \\
6 & (7)\end{array}$ \\
\hline Gender & $\begin{array}{l}\text { male } \\
\text { female }\end{array}$ & $\begin{array}{ll}79 & (86) \\
13 & (14)\end{array}$ \\
\hline Histology & $\begin{array}{l}\text { SCLC } \\
\text { SQCC } \\
A C \\
\text { LCLC }\end{array}$ & $\begin{array}{ll}20 & (22) \\
38 & (41) \\
15 & (16) \\
19 & (21)\end{array}$ \\
\hline Stage SCLC & $\begin{array}{l}\text { limited disease } \\
\text { extensive disease } \\
\text { unknown }\end{array}$ & $\begin{array}{rr}8 & (42) \\
11 & (57) \\
1 & (1)\end{array}$ \\
\hline NSCLC & $\begin{array}{l}\| H I \\
\text { III } \\
\text { IV }\end{array}$ & $\begin{array}{ll}10 & (14) \\
34 & (47) \\
28 & (39)\end{array}$ \\
\hline Ploidy SCLC & $\begin{array}{l}\text { diploid } \\
\text { aneuploid }\end{array}$ & $\begin{array}{rr}17 & (85) \\
3 & (15)\end{array}$ \\
\hline NSCLC & $\begin{array}{l}\text { diploid } \\
\text { anneuploid } \\
\text { unknown }\end{array}$ & $\begin{array}{rr}47 & (65) \\
24 & (33) \\
1 & (2)\end{array}$ \\
\hline
\end{tabular}

SCLC: small cell lung carcinoma; SQCC: squamous cell carcinoma; $A C$ : adenocarcinoma; LCLC: large cell lung carcinoma; NSCLC: non-small cell lung carcinoma; INV: staging according to UICC criteria 


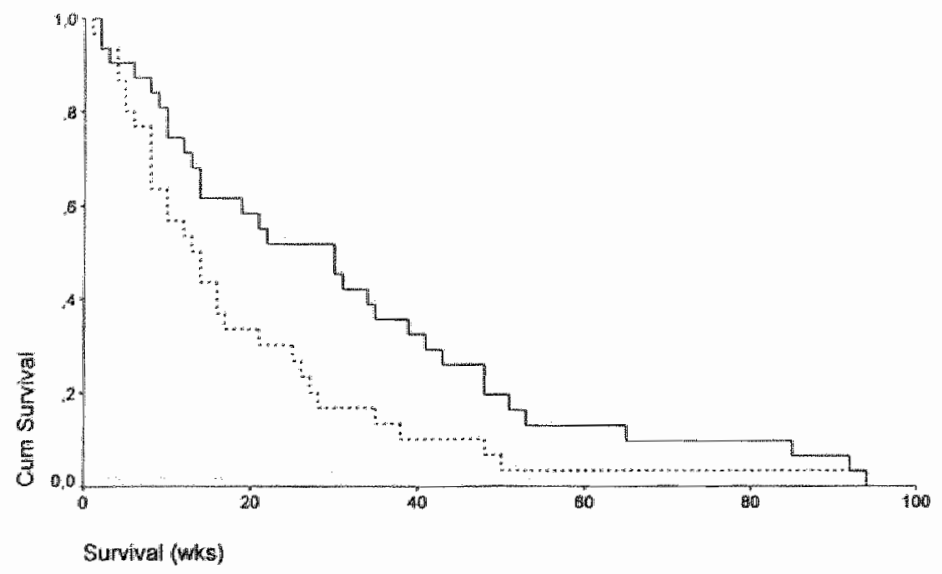

Figure 1. Kaplan-Meier curves of patients with NSCLC, sulbdivided according to potential tumor doubling time $\left(T_{\text {pol }}\right)$. Dotted line: $T_{\text {pot }}$ shorter than the median value $(n=30)$; solid line: $T_{\text {pon }}$ tonger than or equal to the median value $(n=31)$. Logrank test $P$-value $=0,0403$.

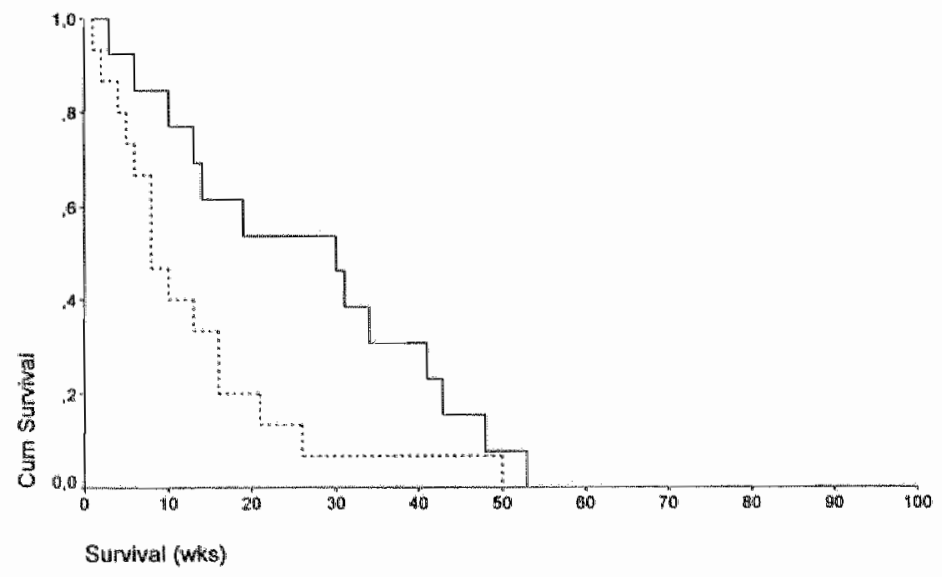

Figure 2. Kaplan-Meier curves of patients with stage IV NSCLC, subdivided according to potential tumor doubling time $\left(T_{\text {peis }}\right)$. Dotted line: $T_{\text {pat }}$ shorter than the median value $(n=15)$; solid line: $T_{\text {por }}$ longer than or equal to the median value $(n=13)$. Logrank test $P$-vallue $=0,0415$. 

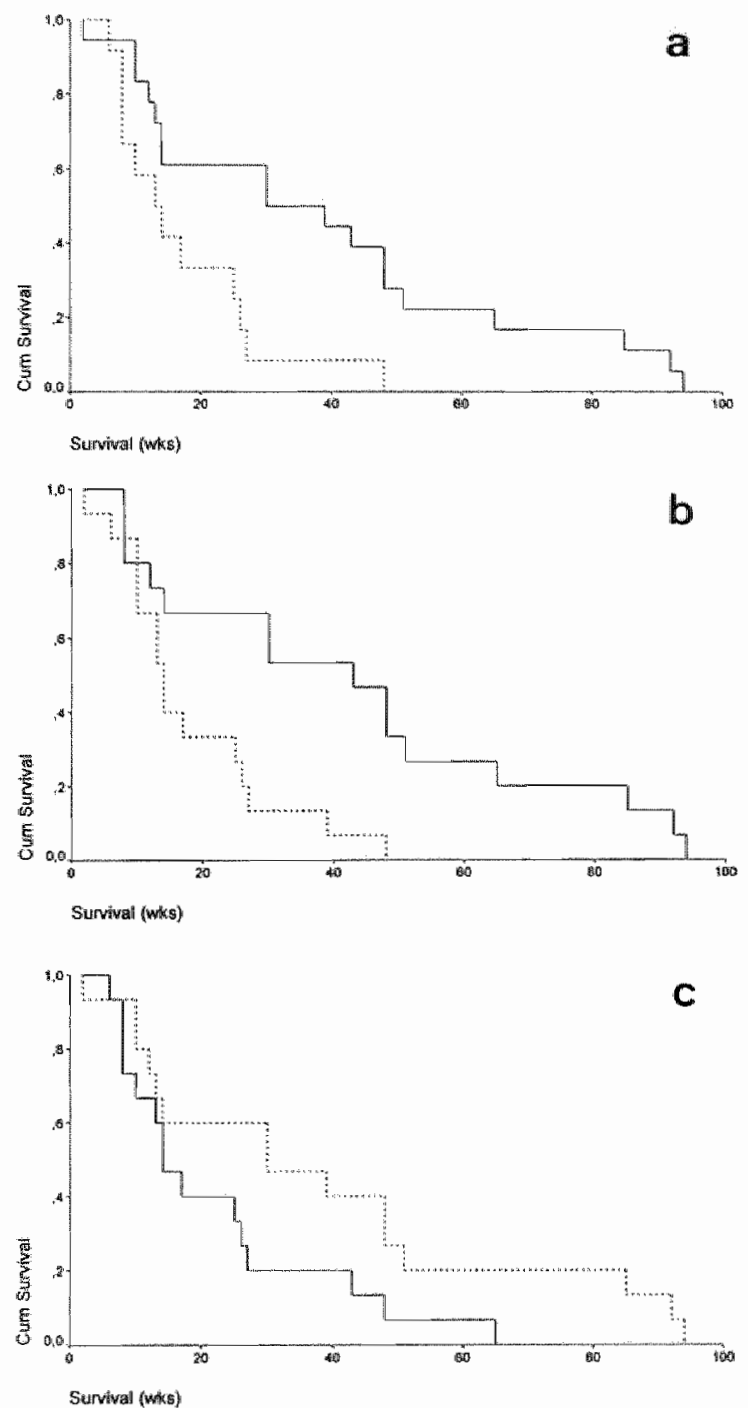

Figure 3. Kaplan-Meler curves of patients with non-squamous NSCLC carcinoma subdivided acconding to (a) $T_{\text {pois }}$ (b) $\mathrm{T}_{\mathrm{s}}$ and (c) LI.

(a) Dotted line: $T_{\text {pot }}$ shorter than the median walue (n-12): solid line: $T$ for Ionger than or equal to the median walue $(n=18)$. Logrank test $P$-walue $=0,0085$.

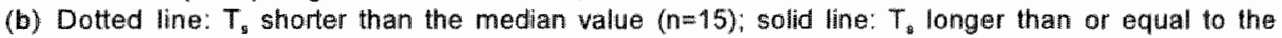
median walue $(n=15)$. Logrank test $P$-value $=0,0051$.

(c) Dotted line: LI smaller than the median value $(n=15)$, solid line: LI greater than or equal to the median walue $(n=15)$. Logrank test $P_{\text {value }}=0,0597$. 
Subset analysis by at chi-square test on contingency tables showed that the parameters $\mathrm{LI}, \mathrm{T}_{\mathrm{g}}, \mathrm{T}_{\mathrm{pat}}$ USPF and $\mathrm{SPF}$ were independent of clinical stage or histologic tumor type. The group of SCLC was too small to draw definitive conclusions from the survival curves. Trends were observed for a survival benefit for patients presenting with limited disease (LD), females and patients younger than 65 years. No indications were found for a prognostic value of any of the cytokinetic parameters (data not shown).

In the group of NSCLC, stage of disease and histology (squamous ws, non-squamous) were found to be significant discriminators for survival. Age, gender and DNA index did not predict survival. Of the cytokinetic parameters, only a short $T$ pot was found to be significantly related to a shorter patient survival (Figure $1 ; p=0.04$ ).

When stratified for stage of disease, the prognostic value of the $T_{\text {pot }}$ was evident in stage IV (Figure $2 ; P=0.04$ ), while no significant differences were observed for this parameter in the stages I-III.

If the analysis was stratified for histology, $T_{\text {por }}$ was particularly significant to predict survival in non-squamous (adenocarcinoma and large cell lung carcinoma) NSCLC (Figure $3 a ; P=0.009$ ). In this subgroup also a short $T$. (Figure $3 b ; P=0.005$ ) and high LI (Figure $30 ; P=0.06$ ) predicted a poor prognosis. Furthermore, a shorter survival time was observed for patients suffering from squamous cell carcinoma with a high USPF as compared to patients presenting with squamous cell carcinoma with a low USPF, although this difference in survival rate was only borderline-significant $(P=0,0529$, data not shown).

\section{Discussion}

In the past, clinical and biological features of lung cancer have been analyzed for their ability to discriminate between patients with good or poor prognosis and to predict response to therapy. Until now, such investigations at the cellular level have mainly concentrated on static parameters, such as ploidy and S-phase fraction. Here we extend such analyses by including data on cell proliferation dynamics.

\section{DNA aneuploidy in lung cancer}

From the flow cytometric analysis of 72 NSCLC specimens, we found DNA ancuploidy in a rather low percentage (33\%) of the investigated cases, but our data were still within the range of the reported aneuploidy rates for this tumor type (Isobe et al. ${ }^{20}$ : $30 \%$ aneuploidy or peridiploidy; Sahin et al ${ }^{32}: 58 \%$ aneuploidy; Tirendelli-Danesi et al. : almost 100\% aneuploidy of which $50 \%$ multiploidy; ten Velde et al ${ }^{46}: 65 \%$ aneuploidy, Volm et al. ${ }^{4}: 83 \%$ aneuploidy of which $25 \%$ multiploidy; Zimmeman et a.. ${ }^{50}: 45 \%$ aneuploidy). 
The relationship between flow cytometrically determined DNA ploidy and patient prognosis is still subject of debate. Several authors found an aneuploid DNA content to be significantly related to a poor prognosis $11,48,50$, in particular in squamous cell carcinoma ${ }^{20,26,32}$, whereas others did not detect a correlation between ploidy and survival in lung cancer ${ }^{8,13,30,46}$. In the present study, no evidence was found for a predictive role of DNA ploidy in NSCLC. The discrepancies between these studies can be caused by methodological variations or differences in the investigated population, such as population size and distribution of stage and histopathologic tumor type.

\section{Prognostic value of cytokinetic parameters}

Good correlations between dynamic cytokinetic characteristics and clinical outcome have been reported in various tumor types. In breast carcinoma and in non-small cell lung carcinoma, $\left[{ }^{3} \mathrm{H}\right]$-thymidine labeling index and percentage S-phase cells both predicted survival time ${ }^{25,48}$. The S-phase fraction (SPF) was also reported to be a significant independent prognostic factor in non-small cell lung tumors ${ }^{45}$. Nagashima et $\mathrm{al}^{28}$ found that ependymomas with a high bromodeoxyuridine ( $\mathrm{BrdU}$ ) labeling index (LI) not only grow faster and are clinically more agressive than tumors with a low LI, but the former have also a strong tendency to recur. Benazzo et al. ${ }^{6}$ found a significantly higher $L I$ and significantly shorter $T_{s}$ and $T_{p o r}$ values in head and neck tumors with lymph node involvement, as compared to lymph node negative samples. Other studies in head and neck carcinoma also suggested a predictive value of $T_{\text {pot }}$ in clinical outcome ${ }^{9,18}$. A short potential tumor doubling time $\left(T_{\text {put }}\right)$ was also found to be significantly linked to shorter relapse-free intervals in various tumor types, while a longer $T_{\text {pot }}$ predicted for longer relapse-free intervals ${ }^{44}$.

In the underlying study, $T_{\text {pot }}$ was found to be an indicator of survival in NSCLC. This was most evident in stage IV of disease and in patients with non-squamous NSCLC. In this latter group a better survival was also associated with a long $\mathrm{T}_{8}$ or low $\mathrm{L}$, although of borderline significance. This is in line with the results from the study of Silvestrini et al. ${ }^{38}$, who found a significantly lower overall survival in patients suffering from stage I non-squamous cell lung carcinoma with a high $\left[{ }^{3} \mathrm{H}\right]$-thymidine $\mathrm{LI}$. In squamous cell carcinoma of the lung we found no prognostic value for $\mathrm{Ll}, \mathrm{T}_{\mathrm{g}}$ or $T_{\text {port }}$. However, patients with squamous cell carcinoma exhibiting a high USPF tended to have a worse prognosis compared to patients with squarnous cell carcinoma and a low USPF (data not shown). This difference, however, was of borderline significance. In a former in vitro study, we have shown that a poor nutritional state, resulting in cell loss (via necrosis and/or apoptosis), is associated with high USPF values ${ }^{41}$. Together this may indicate that a high level of necrosis is associated with poor prognosis, as was also suggested by Shabab et al. ${ }^{35}$

The flow cytometric detection of LI, USPF and SPF in malignancies can be hampered by the presence of non-malignant diploid cells, such as infiltrating leucocytes and 
fibroblasts. The presence of these cells can also infuence the calculation of $T_{8}$ and $\mathrm{T}_{\text {piot }}$. The problem of admixture of non-relevant, stromal cells seems to be most prominent in diploid tumor samples ${ }^{4 Z}$. It is possible that this phenomenon has also an impact on the survival analyses. A solution to this problem is provided by a three color flow cytometric analysis (BrdU/DNA/cytokeratin). In this way, a detailed cytokinetic analysis can be performed on the relevant epithelial cells that are selected based on their cytokeratin expression. The feasibility of this method in fresh as well as in frozen tumor tissue samples has recently been described by Schutte et al. ${ }^{34}$

In conclusion, $T_{\text {pot }}$ has predictive value in NSCLC. This prognostic significance is predominantly found in non-squamous NSCLC carcinomas. Since lung cancer is a very heterogenous disease, knowledge of the cytokinetic behavior of different lung cancer subsets may aid in the fine-tuning of treatment protocols. A crucial factor in defermining the outcome of treatment is repopulation in surviving cells during fractionated therapy. Evidence in human tumors ${ }^{22,29}$ suggests that repopulation rates may vary between different tumors but may be reflected by the $T_{\text {pot }}$ in the untreated tumor ${ }^{44}$. It has been proposed that tumors with a $T_{\text {pot }}$ of 5 days or less may benefit from accelerated fractionation ${ }^{15,39}$. Our data support the concept that information about the $T_{p x p}$ can be of use in the design of treatment schedules ${ }^{3}$.

\section{Acknowledgements}

This study was financially supported by the Dutch Cancer Society (grant no. IKL 90-01) and by the Department of Pulmonology of the University Hospital of Maastricht. 


\section{References}

1 Altman DG: Analysis of survival times. In: Practical statistics for medicai research, pp. 386* 395. Chapman \& Hall; Londen (1991).

2 Auer GU, Caspersson TO, Wallgren AS: DNA content and surviwal in mammary carcinoma. Anal Quant Cytol 2:161-165 (1980).

3 Baisch $\mathrm{H}$, Beck H, Chrisiensen I, Hartmann $\mathrm{N}$, Fried J, Dean P, Gray J, Jett J, Johnston D, White $R$, Nicolini $C$, Zietz $S$, Watson J: A comparison of mathematical methods for the analysis of DNA histograms obtained by flow cytometry. Cell Tissue Kinet 15:235-249 (1982).

Begg AC, McNally NY, Schrieve DC, Kärchner H: A method to measure the duration of DNA synthesis and the potential doubling time from a single sample. Cyrometry 6:620-626 (1985).

Begg AC, Hofland I, Moonen L. Bartelink H, Schraub S, Bontcmps P, Le Fur R, Van Den Bagaert W, Caspers R, Van Gilabbeke M. Horiot JC: The predictive value of cell kinetic measurements in a european trial of accelerated fractionation in advanced head and neck tumors: an interim report. Int J Radiat Oncol Biol Ploys 19:1449-1453 (1990).

Benazzo M, Mevio E, Occhini A, Franchini G, Danova: Proliferative characteristics of head and neck tumors. ORL J Otorhinolaryngol Relat Spec 57:39-43 (1995).

Budke $\mathrm{H}_{3}$ Orazi A, Neiman RS, Cattoreti $\mathrm{G}$, Jolun $\mathrm{K}$, Barberis M: Assessment of cell proliferation in paraffin sections of normal bone marrow by the monoclonal antibodies Ki-67 and PCNA. Modem Pathol 7:860-866 (1994).

8 Bumn PA, Carney DN, Gazdar AF, Whang-Peng J, Matthews MJ: Diagnostic and biological implications of flow cytometric DNA content analysis in lung cancer. Cancer Res 43:5026-5032 (1983).

9 Corvo R, Giareti W, Sanguineti G, Geido E, Orecchia R, Barra S, Margarino G, Bacigalupo A, Vitale $\mathrm{V}$ : Potential doubling time in head and neck tumors treated by primary radiotherapy: preliminary evidence for a prognostic significance in local control. Int J Radiat Oncol Biol Phys 27:1.165-1172 (1993).

10 Coulson PB, Thornthwate JR, Wolley TW, Sugarbaker EV, Seckinger D: Prognostic indicators including DNA histogram type, receptor content and staging related to human breast cancer survival. Cancer Res 44:4187-4196 (1984).

11 Dazzi $H$, Thatcher $N$, Hasleton PS, Swindell $R$ : DNA analysis by flow cytometry in nonsmall cell lung cancer: relationship to cpidemal growth factor receptor, histology, tunour stage and survival. Resp Med 84:21 7-223 (1990).

12 Feld R, Arriagada R, Ball DL, Mattson K, Sorensen JB: Prognostic factors in non-small cell lung cancer: a consensus report. Luhg Cancer 7:3-5 (1991).

13. Fontanini $G$, Macchiarini $P$, Pepe $S$, Ruggiero A, Hardin M, Bigini D, Vignati $S$, Pingitore $\mathbb{R}$, Angeletti $\mathrm{CA}$ : The expression of proliferating, cell nuclear antigen in paraflin sections of peripheral, node-negative non-small cell lung cancer. Cancer 70:1520-1527(1992).

14 Forster G, Cooke TG, Cooke LD, Stanton PD, Bowie G, Stell PM: Tumour growth rutes in squamous carcinoma of the head and neck measured by in wivo bromodeoxyuridinc incorporation and flow cytometry. By J Cancer 65:698-702 (1992).

15 Fowler JF: Potential for increasing the differential response belween tumours and normal lissues. Can proliferation rate be used? In J Radiat Oncol Biol Phys 12:641-645 (1986).

16 Gail MH, Eagan RT, Feld R, Ginsberg R, Goodell B, Hill L, Carmack Holmes EC, Lukeman JM, Mountain CF, Oldham RK, Pearson FG, Wright PW, Lake WH and The Lung Cancer Study 
Group: Prognostic factors in paticnts with resceted slage I non-small cell lung cancer. Cancer $54: 1802-1813(1984)$

17 Harpole DH, Herndon JE, Wolfe WG, Jglehart JD, Marks JR: A prognosuc model of recurrence and death in stage I non-small cell lung cancer wilizing presentation, histopathology, and oncoprotein expression. Cancer Res 55:51-56 (1995).

18. Horiot JC, Maingon P, Barillot I: Radiotherapy for thead nad neck cancers including chemoradiotherapy. Curr Opin Oncol 6:272-276 (1994).

19 Ishida $T$, Kancko $\$$, Akazawa $K$, Tateishi $M$, Sugio K, Sugimachi $K$. Proliferating cell muclear antigen expression and argyrophilic nucleolar organizer regions as factors influencing prognosis of surgically treated lung cancer patients. Cancer Res 53:5000-5003 (1993).

20 Isobe $H$, Miyamoto $H$, Shimizu $T$, Haneda $H$, Hashimoto $M$, Inoue $K$, Mizuno $S$, Kawakami $Y$ : Prognostic and therapcutic significance of the flow cytometric nuclear DNA content in non-small cell lung cancer. Cancer 65:1391-1395 (1990).

2. Kaplan EL, Meier P. Nonparameiric estimation from incomplete observation. J Am Stat Assoc 53:457-481 (1958).

22 Maciejewski $B$, Preuss-Bayer $G$, Trott $K$ - R: The influence of the number of fractions and of owerall trcatment time on local control and late complication rate in squamous cell carcinoma of the Aarynx. Int J Radiat Oncol Biol Phys 9:321-328 (1983).

23 Mclamed MR, Flichinger BJ, Zaman MB: Impact of early detection on the clinical course of lung: cancer. Surg Clin North Am 67:909.924 (1987).

24 Merkel DE, MCGuire WL: Ploidy, proliferative activity and prognosis. Cancer 65:1194-1205 $(1900)$

25 Meyer JS, Coplin MD: Thymidine labeling index, flow cytometric S-phase measurement and DNA index in human tumors. Am J Clin Pathol 89:586-595 (1988).

26 Miyamoto $H$, lsobe $H$, Akita HD, Ishiguro A, Endo $T$, Inoue $S$, Kawakami $Y$ : The flow cytometric nuclear DNA content, tumor origin, nuclear size and prognosis in squamous cell lung. cancer. Imt J Oncol 1:325-329 (1992).

27 Mulshine $J \mathrm{~L}$, Glatstein E, Ruckdeschel JC: Treatment of non-small-cell lung cancer. $J \mathrm{Clin}$ Oncol 4:1704-1715(1986)

28 Nagashima T, Hoshino T, Cho KG, Edwards MSB, Hudgins RJ, Davis RL: The proliferative potential of human ependymomas measured by in situ bromodeoxyuridine labelling. Cancer $61: 2433-2438(1988)$.

29 Parsons $\int$, Bova FI, Million RR: A re-valulation of split-course technique for squamous cell carcinoma of the head and neck. Int J Radiat Onol Brol Phys 6:1645 1652 (1980).

30 Pence JC. Kems B-J, Dodge RK, Iglehart JD. Prognostic significance of the proliferation index in surgically resected non-small cell lung cancer. Apch Surg 128:1382-1390 (1993).

31 Quinn CM, Wright NA: The clinical assessment of proliferation and growth in human tumours: ckaluation of methods and applications as prognostic variables. J Parhol 160:93-102 (1990).

32 Sahin A, Ro JY, El-Naggar AK, Lee IS, Ayala AG, Teague K, Hong WK: Flow cytonetric analysis of the DNA content of non-small cell lung cancer. Cancer 65:530-537 (1990).

33 Schutte B, Reijnders MMJ, Van Assche CLMVJ, Hupperets PSJG, Bosmar FT, Blijham GH: An irmproved method for the immunocytochemical detection of bromodeoxyuridine labeled nuclei using flow cytometry. Cylometry 8:372-376(1987).

34 Schutc B, Tinnemans MMFJ, Pijpers GFP, Lenders M-HJH, Ramaekers FCS: Three parameter flow cytometric analysis: simultancous detection of cylokcralin, proliferation associated antigens and DNA content. Cyometry, in press (1995). 
Shabab I, Fraire AE, Greenberg SD, Johnson EH, Langston C, Roggli VL: Morphometric quantitation of tumor necrosis in stage I non-small cell carcinoma of the lung: prognosic implications. Mod Parhol 5:521-524 (1992).

36 Shimomatsuya $T$, Tanigawa $N$, Muraoka $R$ : Proliferative activity of human tumors: assessmenat using bromodeoxyuridine and llow cytometry. Jpn J Cancer Res 82:357-362 (1991).

37 Silvestrini $\mathbb{R}$ : Cell kinetics: prognostic and therapeutic implications in human tumours. Cell Prollif 27:579-596 (1994).

38 Silvestrini R. Muscolino $G$, Costa A, Lequaglie C, Veneroni S, Mezzanotte G, Ravasi Gi: Could cell kinetics be a predictor of prognosis in non-small cell lung cancer? Lumg Cancer 7:165-170 (1991).

39 Thames HD, Peters LJ, Withers R, Fletcher GH: Accelerated fractionation vs hyperfractionation: Rationales for several treatments per day. Int J Radiat Oncol Biol Phys 9:127-138 (1983)

40 Tinnemans MMFJ, Schutte B, Lenders M-HJH, ten Velde GPM, Ramackers FCS, Blijham GH: Cytokinetic analysis of lung cancer by in wivo bromodcoxyuridine labelling. Br I Cancer $67: 1217-1222(1993)$

4.1 Timnemans MMFJ, Lenders M-HJH, ten Velde GPM, Blijham GH, Ramaekers FCS, Schulte B: S-phase arrest of nutrient deprived lung cancer cells. Cylometry 19:326-333 (1995).

42 Tinnemans MMFJ, Lenders M-HJH, ten Velde GPM, Wagenat SjSc, Blijham GH, Ramackers FCS, Schutte B: Evaluation of proliferation parameters in in vivo BrdU labeled lung cancers. Virchows Archiv, in press (1995).

43 Tirendelli-Danesi D. Teodori L, Mauro F, Modini C, Botli C, Cicconetti F, Stipa S: Prognostic significance of flow cytometry in lung cancer. Cancer 60:844-851 (1987).

44 Trott $\mathrm{K}-\mathrm{R}$, Kummermehr $\mathrm{K}$ : What is known about tumour proliferation rates to choose between accelerated fractionation or hyperfractionation. Radiother Oncol 3:1-9(1985).

45. Tungekar MF, Gatter $\mathrm{KC}$, Dunnill MS, Mason DY: Ki-67 immunostaining and survival in operable lung cancer. Histopathol 19:545-550 (1991).

46 Ten Velde GPM, Schutle B, Vermeulen A, Volovics A, Reijnders MMJ, Blijham GH: Flow cytometric analysis of DNA ploidy level in paraffin-embedded tissue of non-small cell lung cancer. Eur J Cancer Clin Oncol 24:455-460 (1988).

47 Volm M, Hahn EW, Mattern J, Vogt-Moykopf I, Weber E: Five year follow-up study of independent clinical and flow cytometric prognostic factors for the survival of patients with nonsmall cell lung cancer. Cancer Res 48:2923-2928 (1988). Volm M, Mattern J, Sonka J, Vogt-Schaden M, Wayss $K$. DNA distribution in non-small cell lung carcinomas and is relationship to clinical behaviour. Cyometry $6: 348-356$ (1985). White RA, Terry NHA, Meistrich ML, Calkins DP: Improved method for computing potential doubling time from now cytometric data. Cytomerry $11: 314-317(1990)$.

Zimmeman PV, Hawson GAT, Bint MH, Parsons PG: Ploidy as a prognostic determinant in sungically treated lung cancer. Lancet ii:530-533 (1987). 



\section{Evaluation of proliferation parameters in in vivo bromodeoxyuridine labeled lung cancers}

Monique MFJ Tinnemans, Marie-Hélène JH Lenders, Guul PM ten Velde, Sjoerd Sc Wagenaar ${ }^{1)}$, Geert H Blijham, Frans CS Ramaekers and Bert Schutte

Department of Molecular Cell Biology \& Genetics, University of Limburg: Departments of Internal Medicine, Pathology, and Pulmonology, University Hospital Mastricht; Department of Internal Medicine, University Hospital Utrecht. "1) Present address: Departiment of Pathology, Onze Lieve Wroume Gasthuis, Amsterdam. 


\section{Summary}

In series of 44 bronchial biopsies from patients suspected of having endobronchial lung carcinoma, the validity of proliferating cell nuclear antigen (PCNA) and Ki67antigen as proliferative indicators was evaluated in ethanol fixed, paraffin embedded tissue. The percentages of cells positive for these markers were compared to the in vivo bromodeoxyuridine (Brdu) labeling index. A good correlation was found bewween PCNA immunoreactivity and BrdU labeling index, whill Ki67-antigen expression showed a significant relation with BrdU labeling index and with PCNA expression. All three parameters showed a trend towards similar walues for the individual cases. Based on the fact that Ki67-antigen is expressed in all cycling cells, whereas replicon-associated PCNA and BrdU only reflect the S-phase fraction, the differences between Ki67-antigen scores on the one hand and BrdU and PCNA scores on the other were smaller than expected. In order to determine the degree of concordance between immunohistochemically and flow cytometrically detected proliferation variables, BrdU incorporation was measured using both methods in duplicate bronchial specimens. Discrepancies in labeling indices were observed predominantly in DNA diploid samples, with consistently lower values in the flow cytometrically analyzed specimens. In tumor specimens with an aneuploid DNA content, flow cytometric determination of proliferative activity yielded results similar to those obtained by tissue section examination. We conclude that the scores for PCNA and Ki67-antigen, immunohistochemically detected in ethanol fixed, paraffin embedded tissue reflect functional proliferative activity.

\section{Introduction}

Immunohistochemical studies of proliferative activity show that the detection of cell cycle parameters in tumor tissue sections may be a useful tool in the determination of prognostic indicators and in the evaluation of treatment response $e^{10,11,13,39,46,33}$. The use of immunohistochemical methods to detect molecules involved in cell cycle regulation and DNA replication is nowadays instrumental in this approach, in particular since it has become applicable to paraffin embedded tumor material.

Two of the most commonly used proliferation-associated proteins are proliferating cell nuclear antigen (PCNA) and Ki67-antigen. PCNA functions as an auxillary protein for polymerase- $8^{4,3,42}$ and thus appears to be involved in DNA replication ${ }^{32,41}$. The synthesis of PCNA reaches its maximum during the S-phase and it is rapidly degraded thereafter, ${ }^{726}$. In this study we have used a monoclonal antibody (PC10) that recognizes PCNA in routinely fixed and histologically processed material developed by Waseem and Lane ${ }^{52}$. 
The Ki67-antigen comprises a nuclear matrix protein expressed in all cycling cells ${ }^{15,50,51}$ and in the past years, Ki67-antigen staining has become a standard procedure in the assessment of the extent of cell proliferations. Recently, monoclonal antibodies have been developed that are directed against Ki67-antigen-epitopes resistant to formalin fixation ${ }^{22}$, MIB-1 giving the best results after microwave pretreatment ${ }^{6}$.

When comparing reports in the literature on the expression of PCNA and Ki67. antigen, one is often confronted with inconsistent results. Fixation and staining methods appear to be crucial in influencing the final scores ${ }^{12,27}$. For example, at least two intracellular forms of PCNA exist ${ }^{3}$, a replicon-associated form, which is resistant to alcohol fixations and non-ionic detergents, and an alcohol soluble form ${ }^{8}$. The latter is not associated with S-phase activity and is present in almost all cycling cells. Therefore, alcohol fixation or extraction is applied to cells and tissues to be subjected to cell cycle dependent PCNA staining.

The immunohistochemical assessment of PCNA and Ki67-antigen in tissue sections may pose some difficulties with respect to the interpretation of the data. First of all, it is often not evident to what extent the data obtained by immunohistochemistry represent actual proliferation. For example, Ki67-antigen is only weakly expressed in early $G_{1}$-phase cells ${ }^{2,15}$, and the procedure may therefore fail to detect these cells. Several authors have reported relatively low Ki67-antigen scores as compared to other proliferation indicators, such as PCNA or bromodeoxyuridine (BrdU) $)^{19.21,54}$. Furthermore, cells in culture show loss of Ki67-antigen immunoreactivity during nutritional deprivation ${ }^{1,48,51}$

In this study, the expression of PCNA and Ki67-antigen is compared to in vivo BrdU incorporation in ethanol fixed, paraffin embedded bronchial biopsies. Our aim was to determine the validity of these markers as quantitative indicators of proliferation. $\mathrm{BrdU}$, a thymidine analogue, is incorporated into the newly replicated DNA of Sphase cells. Therefore, the BrdU labeling index is a measure of functional proliferative activity $^{31,47}$. An established method to detect the BrdU labeling index is flow cytometry and although this technique has the advantage of analyzing a large number of cells when compared with immunohistochemical evaluation of tissue sections, the advantage of the latter method is that the tissue architecture can be included in the evaluation and individual proliferating cells can be visualized in their local context. Flow cytometric analyses may also be disturbed by the admixture of non-malignant cells, such as stromal cells. Since this problem is particularly prominent in biopsy samples, which are usually small sized, we have determined the correlation between immunohistochemically and flow cytometrically detectable BrdU incorporation in such specimens. 


\section{Materials and Methods}

\section{Patient material}

The bronchoscopic biopsies used in this study were duplicate specimens of the biopsies obtained for the study described by Tinnemans et al. ${ }^{43}$ Approval for in vivo labeling with BrdU was given by the ethical committee of the University Hospital Masstricht. After informed consent, the patients were infused with $50 \mathrm{mg} / \mathrm{m}^{2} \mathrm{BrdU}$ (Janssen Pharmaceutica, Beerse, Belgium), dissolved in $100 \mathrm{ml} 0.9 \%$ sodium chloride, within a timespan of 10 min. After approximately $4-5 \mathrm{~h}$, biopsies were taken with a flexible bronchoscope, fixed in formalin for routine diagnosis and in cold $\left(4^{\circ} \mathrm{C}\right) 70 \%$ ethanol for the immunohistochemical studies. The latter samples were stored at $4^{\circ} \mathrm{C}$ until use. Specimens from 38 males and 6 females were included in this study. The evaluated cases were divided into two groups: a group with tumor tissue or at least carcinoma in situ (CIS) found in the biopsy (tumor group) and a group with normal bronchial epithelium or metaplasia found in the biopsy (non-tumor group). Each specimen was allocated to only one group. Almost all patients had bronchial carcinoma although this was not always detectable in the biopsies obtained for this study. In Table I the distribution of different types of bronchial carcinoma is given for these 44 patients.

Table I. Distribution of lung cancer type and stage of patients from which the biopsies were derived.

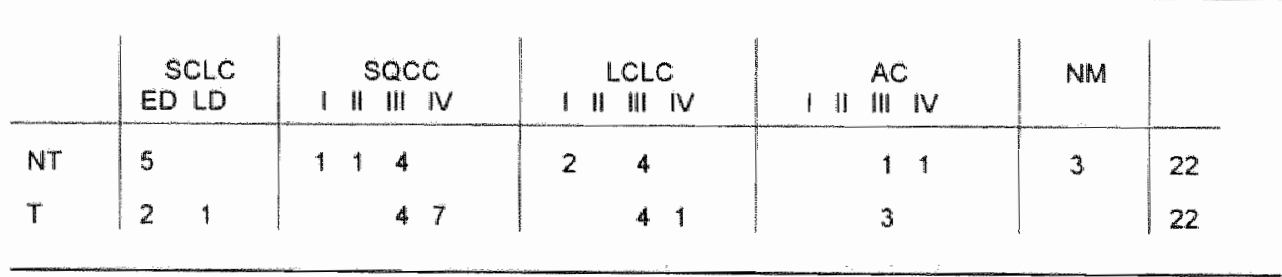

SCLC: small cell lung carcinoma; SQCC: squamous cell carcinoma; LCLC: lange cell lung carcinoma; AC: adenocarchoma; NM: non malignant; ED: extended disease; LD: limilled disease; NT: non-tumor group: T: turmor group: HV: staging according to UlCC criteria 


\section{Primary antibodies}

For PCNA staining we used the monoclonal antibody PC10 2 , kindly supplied by Dr. D. Lane (Dundee, UK). Ki67-antigen was detected using the monoclonal antibody $\mathrm{MIB}-1^{22}$, which was a gift from Dr. J. Gerdes (Forschungsinstitut Borstel, Germany). The monoclonal antibody against BrdU (clone IIB5) was raised and characterized as described before ${ }^{36}$.

\section{Immunohistochemistry}

Forty-four bronchial specimens, fixed in $70 \%$ ethanol, were paraffin embedded and 4 $\mu \mathrm{m}$ sections were cut. After removal of paraffin by xylene and rehydration, endogenous peroxidase activity was blocked in methanol containing $0.3 \%$ hydrogen peroxide for $20 \mathrm{~min}$. Slides were rinsed in phosphate buffered saline (PBS) and immunohistochemical procedures were applied. Different procedures were followed for immum nostaining of BrdU, PCNA and Ki67-antigen.

BrdU staining. Slides were incubated in $2 \mathrm{~N}$ hydrochloric acid (HCl) for $30 \mathrm{~min}$ at $37^{\circ} \mathrm{C}$ to denature nuclear DNA, followed by two washing steps in Borax buffer $(0.1 \mathrm{M}$ sodium tetraborate in destilled water, $\mathrm{pH} 8.5$ ) and two washing steps in PBS. The slides were then incubated with appropriately diluted anti-BrdU antibody for $60 \mathrm{~min}$ at $37^{\circ} \mathrm{C}$. After rinsing in PBS, primary antibody binding was visualized by incubation with peroxidase-conjugated rabbit-anti-mouse $\operatorname{IgG}$ (DAKO A/S, Glostrup, Denmark, code P260) diluted 1:200 in PBS, for 60 min at room temperature (RT). 3,3'-Diaminobenzidine tetrahydrochloride (DAB) (Sigma, St. Louis, Mo., USA) was used as the chromogen. Finally, the sections were lightly counterstained with haematoxylin, dehydrated and coverslipped.

PCNA staining. Slides were incubated with the monoclonal antibody PC 10 , diluted 1:25 in $\mathrm{PBS}$, for $60 \mathrm{~min}$ at $37^{\circ} \mathrm{C}$. After a washing step in PBS, primary antibody binding was visualized with peroxidase-conjugated rabbit-anti-mouse $\lg G$, and the slides were further processed as described above.

Ki67-antigen staining. Slides were placed in a slide rack and immersed in $500 \mathrm{ml}$ $0.01 \mathrm{M}$ citrate buffer ( $\mathrm{pH} 6.0$ ) in a plastic microwave container. They were boiled for 15 min at maximum power $(850 \mathrm{~W})$ in a microwave oven (Moulinex Oscillotron). During this process, slides were kept immersed in buffer. Then, slides were allowed to cool down to RT for 60 min. They were rinsed in PBS and incubated for 60 min at RT with MIB-1 antibody, diluted 1:20 in PBS. After a washing step in PBS, primary antibody binding was visualized by incubation with peroxidase-conjugated rabbit-antimouse $\operatorname{IgG}$, and slides were further processed as described above.

Controls. Positive controls consisted of in vivo BrdU-labeled human tumor specimens known to be positive for BrdU, PCNA and Ki67-antigen. Negative controls consisted 
of non-BrdU labeled human colon specimens. In control incubations the primary antisera were replaced by PBS or, in case of a control for anti-BrdU, the $\mathrm{HCl}$ denaturation step was omitted.

\section{Evaluation}

All sections were evaluated under the supervision of an experienced pathologist $(\mathrm{SjScW})$. Tumor tissue areas, as well as areas displaying normal tissue, metaplasia or dysplasia, were marked. In these different areas, the percentages of cells showing specific BrdU, PCNA or Ki67-antigen expression were determined. No correction was made for division of BrdU labeled cells in the time lapse between BrdU administration and biopsy sampling, since the fraction of BrdU labeled $G_{1}$-phase cells was found to be negligible. Three series of 200 cells were courted in various representative fields in each section, in order to minimalize intraobserver variations. Stained nuclei were considered positive, irrespective of intensity. In biopsies with heterogeneously staining tumor fields, the fields examined included those with the highest and those with the lowest percentage of stained cells. The results were averaged.

Not all biopsies contained sufficient material to evaluate all three parameters. In several slides, part of the epithelial tissue was damaged or completely lost. These areas were omitted from evaluation, and so were tangentially cut areas, in order to avoid under- or overestimation of the growth fraction.

Dysplastic tissue and tumor tissue were often found together within one section. These cases were included in the tumor group and only the areas containing tumor cells were analyzed.

\section{Statistical analysis}

Histograms showed serious skewing of the data and unequal standard deviations were observed between the two groups. To correct for the skewing, a logarithmic transformation was performed ${ }^{23}$. To this end, all data were upgraded by 1 , to include zero values. Transformation to a different scale also resulted in approximately equal standard deviations, thus allowing the use of a Student's $t$-test (with pooled variance estimate) for comparison of two samples. 


\section{Results}

Fourty-four bronchial biopsies of patients suspected of having endobronchial lung carcinoma were analyzed ( 38 males, 6 females). In 22 cases, only normal bronchial epithelium was found. In some of these biopsies dysplasia or metaplasia occurred next to normal tissue. The remaining 22 biopsies clearly showed regions of tumor.

Since some of the sections obtained from one biopsy only contained stromal tissue and could not be replaced by another section because of size, only $68 \%$ of the cases could be analyzed for all three parameters. In $32 \%$ of the biopsies only one or two parameters could be evaluated.

\section{Comparison of proliferation parameter scores}

The non-tumor and tumor groups were compared with regard to average scores of PCNA, Ki67-antigen and BrdU positivity. In general, biopsies in which carcinoma cells or CIS were detected showed elevated proliferative markers when compared with biopsies in which no tumor tissue was found (Table II). Large standard deviations were observed for each variable. In a two sample $t$-test using logarithmically transformed data, $P$-values lower than 0.05 indicated a significant difference between the proliferation parameter scores of the non-tumor and the tumor group. Comparison of average $\mathrm{Ki} 67$-antigen and $\mathrm{BrdU}$ values on the one hand, and of average Ki67-antigen and PCNA values on the other within the tumor group, revealed a lower number of Ki67-antigen-positive cells than would be expected, considering the fact that Ki67antigen is expressed in all cycling cells whereas PCNA and BrdU only reflect the Sphase fraction.

Table II. Averages and ranges of scores for proliferating cell nuclear antigen (PCNA), KiGTantigen and bromodeoxyuridine $(B r d U)$ positive cells in the non-tumor (NT) and fumor (T) group. P-values were obtained using a two-sample $t$-test after logarithmic transformation of the data.

\begin{tabular}{l|c|c|c} 
& $\%$ PCNA+ (range) & $\%$ Ki67+ (range) & $\%$ BrdU+ (range) \\
\hline NT & $1(0-7)$ & $3(0-22)$ & $3(0-6)$ \\
$T$ & $24(0-63)$ & $24(3-78)$ & $17(3-46)$ \\
\hline P-value & $2 E-7$ & $3 E-8$ & $5 E-7$
\end{tabular}


The paired values for the proliferation markers Ki67-antigen and PCNA were compared with each other and with BrdU incorporation data (Figs. 1-3). Logarithinically transformed data were used. When individual PCNA scores were compared with the corresponding BrdU labeling indices, a significant correlation $(P<0.05)$ was found between these markers. Similarly, a significant correlation between BrdU labeling index and Ki67-antigen expression and between PCNA and Ki67-antigen expression was seen $(P<0.05)$. All three parameters showed a trend towards similar values for the individual cases.

\section{Comparison of flow cytometry and immunohistochemistry}

In order to evaluate the degree of concordance between flow cytometry and immunohistochemistry, we compared parallel biopsies in which the BrdU labeling index was determined either in the tissue sections or in cell suspensions in 32 cases. We expected that differences, if any, in outcome between flow cytometry and immunohistochemistry would be most prominent in diploid tumors, given the problem of admixture of non-proliferating tissue. Therefore, we distinguished between DNA diploid and

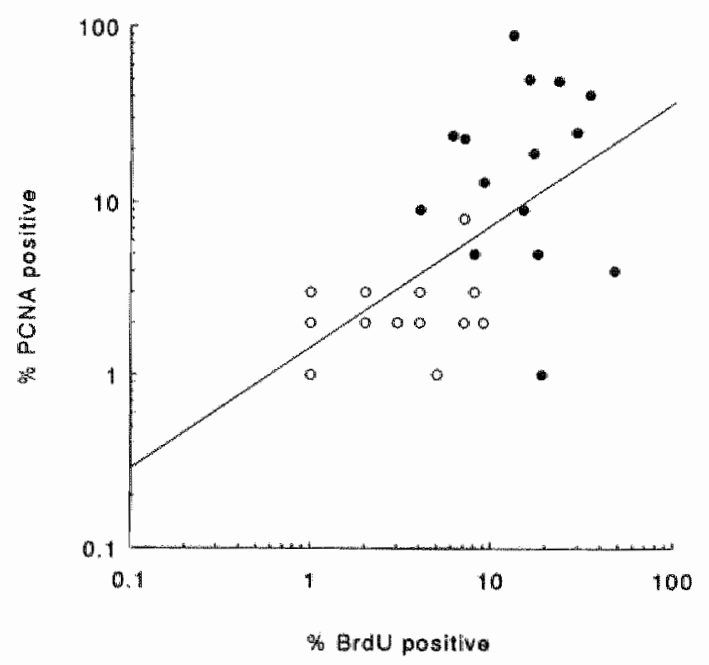

Figure 1. Percentages of cells with bromodeoxyuridine (BrdU) labeling ( $X$-axis) versus cells expressing proliferating cell nuclear antigen (PCNA: $Y$-axis). A significant correlation was found $(P=0,00054)$. Data from the nontumor group (open circles) as well as from the tumor group (rilled circles) are included. 


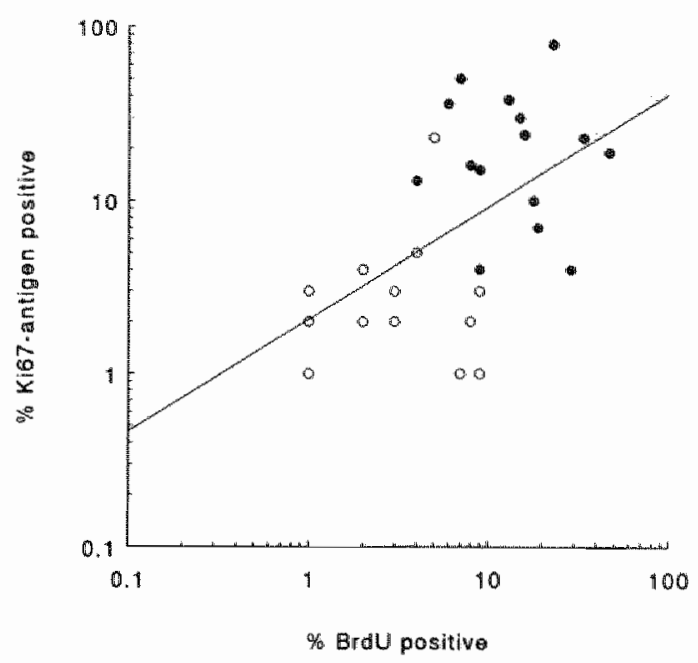

Figure 2. Percentages of cells with BrdU labeling ( $\mathcal{X}$-axis) versus cells expressing Ki67-antigen ( $\gamma$-axis). A significant correlation was found $(P=0.002)$. Data from the non-tumor group (open circles) as well as from the tumor group (filled circles) are included.

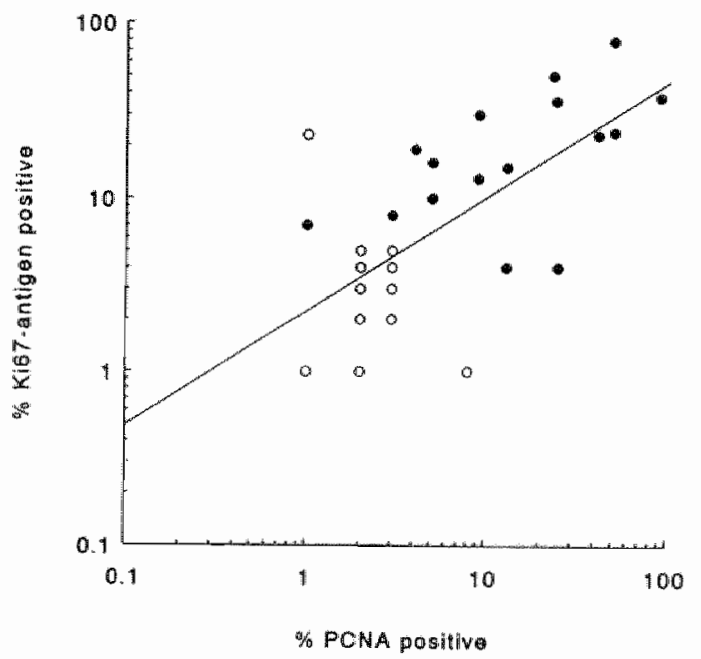

Figure 3. Percentages of cells expressing PCNA (X-axis) versus celts expressing Ki67-antigen ( $\gamma$-axis). A significant correlation was found $(P=0,00002)$. Data from the nontumor group (open circles) as well as from the tumor group (filled circles) are included. 
DNA ancuploid biopsies. Figure 4 shows the BrdU labeling index, determined from sections of ethanol fixed, paraffin embedded cells and the BrdU labeling index of parallel biopsies obtained from the same patients, flow cytometrically deternined from ethanol fixed nuclei in a former study ${ }^{43}$. In DNA diploid biopsies, the BrdU labeling index is underestimated using flow cytometry. In DNA aneuploid biopsies, the differences seemed more random and no systematic under-or overestimation was observed using either of the two methods.

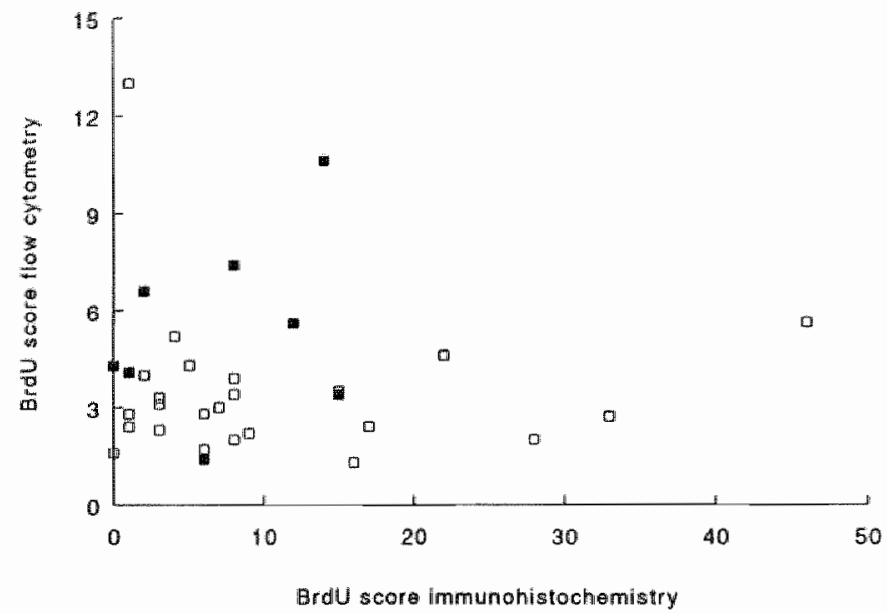

Figure 4. Brdu labeling indices determined immunohistochemically on sections $(X$-axis) versus BrdU labeling indices determined flow cytometrically in suspension ( $Y$-axis). Data from DNA diploid samples (open squares) as well as from DNA aneuploid samples (filed squares) are included.

\section{Discussion}

The proliferation markers PCNA and Ki67-antigen were compared with in vivo BrdU incorporation in a series of bronchial biopsies, comprising 22 samples containing lung carcinomas and 22 samples with normal bronchial epithelium and/or metaplasia. In most of the comparative studies performed ${ }^{20,25,30,35,49}$, BrdU was administered after excision of the tissue or in vitro. However, the ex vivo labeling assays are sensitive to technical variability, since they rely on an efficient diffusion of the label, while the results of cell culture assays often do not reflect the growth conditions in situ. 
In concordance with the BrdU labeling indices, scores of Ki67-antigen and PCNA were significantly elevated in the tumor group when compared with the non tumor group. The high variance in the tumor group may reflect the inter- and intra-tumoral heterogeneity in proliferation which is a well established phenomenon ${ }^{30}$.

\section{PCNA versus BroU}

We found a significant correlation between individual BrdU and PCNA scores. This is constistent with the assumption that the replication-associated form of PCNA remaining in the cell after alcoholic fixation, reflects the S-phase fraction ${ }^{8}$. In an immunocytochemical study of PCNA expression and BrdU incorporation in lung cancer cell lines, we observed that both are found in the same cell population and colocalize in the nucleus (Schutte et al., unpublished data). The same was described by Humbert et al. ${ }^{20}$, who reported a comparable distribution of PCNA and BrdL within the nuclei of methanol-fixed MCF-7 cells. Sasaki et al. ${ }^{34}$ also found matching distribution patterns of PCNA and BrdU in methanol fixed, Triton X-100 extracted cells. PCNA, detected in ethanol fixed paraffin embedded tissue, thus appears to be a reliable indicator of functional proliferative activity. Reports suggest that the detectability of PCNA is strongly dependent on the type and duration of fixation ${ }^{3,12,13,14,24,27,34}$. In studies where formalin was used as a fixative, PCNA scores are often reported to be higher than the corresponding BrdU labeling indices ${ }^{9,29,38}$, or than the flow cytometrically determined S-phase fraction ${ }^{18}$, probably due to the formalin resistant, non-specific form of PCNA. Studies describing the use of alcoholic fixatives usually report a good correlation between PCNA expression and BrdU labeling index ${ }^{20,25,30,35,49}$.

\section{Ki67-antigen versus BrdU and PCNA}

A significant correlation was found when Ki67-antigen expression was compared with BrdU incorporation and with PCNA expression. Being expressed in all cycling cells ${ }^{15}$, Ki67-antigen immunoreactivity was expected to exceed the labeling indices of PCNA and BrdU, which merely represent the S-phase fraction. However, we did not observe a systematically higher Ki67-antigen score. An explanation for this finding may be that Ki67-antigenicity is lost as a result of environmental factors. Verhejien et all." reported loss of $K$ i67-antigen reactivity in nutritionally deprived cells which were still in $\mathrm{S}, \mathrm{G}_{2}$ or $\mathrm{M}$-phase, as measured by flow cytometry. Similarly, Baisch and Gerdes' and Van Dierendonck et al reported loss of correlation between Ki67-antigen immunoreactivity and proliferation during nutrient deprivation. In a study of nutritionally depleted small cell lung cancer cells, a gradual disappearance of PCNA and Ki67-antigen was observed, showing a more rapid decline of the latter ${ }^{4}$. Another explanation for the low Ki67-antigen scores is that cells express Ki67-antigen below 
the detection level. Lack of $\mathrm{Ki67}$ antigenicity in early $\mathrm{G}_{1}$-phase cells is a frequently described phenomenon ${ }^{2.15,16}$. Tsurusawa and Fujimoto ${ }^{45}$ reported a down regulation of Ki67 wantigen expression to an undetectable level in tumor cells with relatively long $G_{1}$ phase duration. Landberg and $\operatorname{Roos}^{28}$ found that $G_{1}$-phase cells in the first cell cycle are Ki67-antigen negative, while continuously cycling cells express Ki67antigen also in $\mathrm{G}_{1}$.

\section{Flow cytometry versus immunohistochemistry}

To investigate the concordance between flow cytometry and immunohistochemistry in the evaluation of proliferation markers, we compared BrdU labeling indices determined from immunohistochemically stained sections with data of duplicate bronchial specimens, evaluated flow cytometrically. The small discrepancies that were observed in DNA aneuploid tumors seemed random, and can be explained by differences in sample size. In DNA diploid samples however, the discrepancies observed were more extensive. A likely explanation for this phenomenon is the admixture of nonproliferative cells in the flow cytometric sample, resulting in an underestimation of the labeling index. Although, in contrast to the tissue section method, the use of flow cytometry enables the evaluation of large cell numbers, this technique does not enable selection of relevant cells. This problem is predominantly present in DNA diploid samples, where DNA ploidy cannot serve as a selection criterion. A solution for this problem is immunostaining with cytokeratin prior to or simultaneously with staining for BrdU, PCNA or Ki67-antigen. This procedure has been proven feasible by Schutte et $a .^{37}$, who showed that three parameter analysis of patient biopsies offers the possibility of enriching the tumor cell population by gating on epithelial cells.

In conclusion, our results indicate that scores for PCNA and Ki67-antigen expression are reliable indicators of proliferative activity in ethanol fixed, paraffin embedded tissue. The results obtained for these two cell cycle parameters correlate significantly with in vivo incorporated BrdU values. These findings therefore justify the diagnostic use of PCNA and Ki67-antigen.

\section{Acknowledgements}

We would like to thank Dr. J. Gerdes (Forschungsinstitut Borstel, Germany) and Dr. D. Lane (Dundee, UK) for kindly providing us with the antibodies used in the experiments described in this paper, and Dr. H. Schouten (Department of Methodology Se Statistics, University of Limburg. The Netherlands) for statistical advice. This study was supported by the Dutch Cancer Sociecy (IKL90-01). 


\section{References}

1 Baisch H, Gerdes J: Simultancous staining of exponentially growing versus plateau phase cells with the proliferation-associated antibody $\mathrm{Ki} 67$ and propidium iodide: Analysis of now cytometry. Cell Tissue Kiner 20:387-391 (1987).

2 Braun N, Papadopoulos T, Müller-Hermelink HK: Cell cycle dependent distribution of the proliferation-associated Ki-67 antigen in human embryonic lung cells. Virchows Arch [B] 56:25. $33(1.988)$

3 Bravo $\mathbb{R}$, Macdonald-Brawo $\mathrm{H}$ : Existence of two populations of cyclin/proliferating cell nuclear antigen during the cell cycle: association with DNA replication sites. J Cell Biol 105:1549-1554 (1987)

4 Bravo $R$, Frank R, Blundell PA, Macdonald-Bravo H: Cyclin/PCNA is the auxillary protein to DNA polymerase-delta. Narure 326:515-517 (1987).

5 Brown DC, Gatter KC: Monoclonal antibody Ki-67: its use in tistopathology. Histopathology 17:489-503 (1990).

6 Cattoretti G, Becker MHG, Key $G$, Duchrow M, Schluter C, Galle J, Gerdes J: Monoclonal antibodies against recombinant parts of the Ki67 antigen (MIB 1 and MIB 3) detect proliferating cells in micro-wave-processed formalin-fixed paraffin sections. J Pathol 168:357-363 (1992).

7 Celis JE, Celis A: Cell cycle-dependent variations in the distribution of the nuclear protein cyclin proliferation cell nuclear antigen in cultured cells: subdivision of S-phase. Proc Natl Acad Sct USA 82:3262-3266 (1985).

8. Coltrera MD, Skelly M, Gown AM: Anti-PCNA antibody PCI0 yiclds unreliable proliferation indexes in routinely processed, deparaffinized, formalin-fixed tissue. Appl Immunohistochem 1:193-200(1993).

9 Connolly KM, Bogdanffy $\mathbb{M S}$ : Evaluation of proliferating cell nuclear antigen (PCNA) as an endogenous marker of cell proliferation in rat liver; a dual-siain comparison with 5-bromo-2'deoxyuridine. J Histochem Cytochem 41:1-6 (1993).

10 Fontana $D$, Bellina $M$, Gubetta $L$, Fasolis $G$, Rolle $L$, Scollone $C$, Porpiglia $F$, Colombo $M$, Tarabuzzi R, Leonardo E: Monoclonal antibody $\mathrm{Ki}-67$ in the study of the proliferative activity of bladder carcinoma, $J$ Urol 148:1149-1151 (1992).

11 Fontanini G, Macchiarini P. Pepe S, Ruggiero A, Hardin M, Bigini B, Vignati S, Pingitore R, Angeletti $A$ : The expression of proliferating cell nuclear antigen in paraffin sections of peripheral, node-negative non-small cell lung cancer. Cancer 70:1520-1527 (1992).

12 Galand $\mathrm{P}$, Degraef C. Cyclin/PCNA inmunostaining as an alicrnative to trithated thymidine pulse labeling for marking $S$ phase cells in paraffin sections from animat and human tissucs. Cell Tissue Kinet 22:383-392 (1989).

13 Garcia RL, Coltrera MD, Gown AM: Analysis of proliferative grade using anti-PCNA/cyclin monoclonal antibodics in fixed, cmbedded tissues: comparison with flow cytometric analysis. Am I Parhol 134:733-739 (1989).

14 Geb AB, Kamel OW, LeBrun DP, Warnke RA: Estimation of wmor gronth fractions in archival formalin-fixed, paraflin-embodded tissues using two anti-PCNA/cyclin monoclonal antibodies. Am J Pathol $141: 1453-1458$ (1992).

15 Gerdes $J$, Lemke H, Baisch $H$, Wacker H-H, Schwab U, Stein H. Cell cycle analysis of a cell proliferation-associated human nuclear antigen defined by the monoclonal antibody Ki67. I Immunol 133:1710-1715(1984). 
Guillaud P. Du Manioir 3 , Seigneurin D. Quantification and topographical description of Ki-67 antibody labelling during the cell cycle of normal fibroblastic (MRC-5) and mammary tumour cell lines (MCF-7). Anal Cell Pathol 1:25-39 (1989). Hall PA, Woods AL: Immunohistochemical markers of cell proliferation. Cell Tissue Kinet $23: 505.522(1990)$ Hall PA, Levison DA, Woods AL, Yu CC-W, Kellock DB, Watkins JA, Bames DM, Gillett CE, Camplejohn $R$, Dover $R$, Waseem NH, Lane DP. Proliferating cell nuclear antigen (PCNA) immunolocalization in paraffin sections: an index of cell proliferation with evidence of deregulated expression in some neoplasms. I Pahol 162:285-294 (1990).

Harper ME, Glynne-Jones E, Goddard L, Wilson DW, Matenhelia SS, Comn IG, Peeling WB, Griffiths $K$ : Relationship of proliferating cell nuclear antigen (PCNA) in prostatic carcinomas to various clinical parameters. Prostate 20:243-253 (1992).

Humbert C, Santisteban MS, Usson Y, Robert-Nicoud M: Intranuclear co-location of newly replicated DNA and PCNA by simultaneous immunofluorescent labelling and confocal micrascopy in MCF.7 cells. I Cell Sci 103:97-103 (1992).

Kelleher L, Magee HM, Dervan PA: Evaluation of cell-proliferation antibodies reactive in paraffiri sections. Appl Immunohistochem 2:164-170(1994).

Key G, Becker MH, Baron B, Duchrow M, Schlüter C, Flad HD, Gerdes I: New Ki67-cquivalent murine monoclonal antibodies MiB1-3 generated against bacterially expressed parts of the Ki67 cDNA containing three 62 base pair repetitive elements encoding for the Ki67 epitope. Lab Invert 68:629:636 (1993). Kirkwood B: Essentials of medical statistics. Blackwell, Oxford, pp 138-146 (1988). Kreipe H, Heidebrecht HJ, Hansen S, Röhlk W, Kubbies M, Wacker HH, Tiemann M, Radzun HJ, Parwarescli R: A new proliferation-associated nuclear antigen detectable in paraffinembedded tissues by the monoclonal antibody Ki-SI. Am J Pothol 142:3-9 (1993).

Kubben FJGM, Pecters-Hacsevocts A, Engels LGJB, Baeten CGMI, Schutte B, Arends JW, Stockbrugger RW, Bligham GH: Proliferating cell nuclear antigen ( $\mathrm{PCNA}$ ): a new marker to study human colonic cell proliferation. Gu 35:530-535 (1994).

26. Kurki P, Vanderlaan M, Dolbeare F, Gray J, Tan EM: Expression of proliferating cell nuclear antigen (PCNA)/cyclin during the cell cycle. Lxp Cell Res 166:209-219 (1986).

27 Landberg G, Roos G: Antibodies to protiferating cell nuclear antigen as $S$ phase probes in flow cytometric cell cycle analysis. Cancer Res $51: 4570-4574$ (1991).

28 Landberg G, Roos G: Proliferating cell nuclear antigen and Ki-67 antigen expression in human haematopoidic cells during growth stimulation and difrerentiation. Cell Prolif 26:427-437 (1993).

29 Leonardi E, Girlando S, Serio G, Mauri FA, Perronc G, Scampini S, Dalla Palma P, Barbareschi M: PCNA and Ki67-expression in breast earcinoma: correlations with clinical and biological variables. J Clin Pahol 45,416-419(1992).

30 Lolur F, Wenz F, Haas S. Flentje M: Comparison of proliferating cell nuclear antigen (PCNA) staining and BrdUrdabelling index under different proliferative conditions in vitro by flow cytometry. Cell Prolif 28:93-104 (1995).

31 Meyer JS, Nauen J, Koellm S: Cell kinetics of human umors by in vitro bromodeoxyruridine labeling. J Histochem Cyrochem 37:1449-1454 (1989).

32 Ogata K, Kurkil P, Celis JE, Nakamura RM, Tan EM: Monoclonal antibodies to a nuclear protein (PCNA/cyclin) associated with DNA replication. Exp Cell Res 168:475-486 (1987).

33 Prelich $G$, Tan $C K$, Kostura M, Mathews MB, So AG. Downey KM, Stillman B: Functional identity of proliferating cell nuclear antigen and a DNA polymerase-delta auxiliary protein. Nature 326:517-520(1987). 
34 Sasaki $K$, Kurose A, Ishida $Y$. Flow cytometric analusis of the expression of PCNA during the cell cycle in Hela cells and effects on the inhibition of DNA synthesis on it. Cyowetm 14:876$882(1993)$.

35 Sasaki $K$, Kurose $A_{3}$ Ishida $Y$, Matsuta $M$ : Estimation of S-phase fratetion in tumor tissue sections by immunohistochemical staining of PCNA. I Histochem Cytochem 42:957-960 (1994).

36 Schutte B, Reynders MMJ, Van Assche CLMVI, Hupperets PSIG, Bosman FT, Blijhan GH An improved method for the immunocytochemical detection of bromadooxyuridine labeled nuclei using flow cytometry. Cylometry 8:372-376 (19:7).

37 Schutte B, Tinnemans MMFJ, Pijpers GFP, Lenders M-HJH, Ramackers FCS: Three parameter flow cyiometric analysis: simultaneous detection of cytokeratin, proliferation associated antigens and DNA content. Cytometry, in press (1995).

38 Scott RJ, Hall PA, Haldane JS, Van Noorden S, Price Y, Lanc DP, Wright NA A comparison of immunohistochemical markers of cell prollferation with experimentally determined growth fraction. I Pathol 165:173-187 (1991)

39 Silvestrini $R$ : Cell kinetics: prognostic and therapeutic implications in human tumours. Cell Prolif 27:579-596(1994).

40 Sieel GG: Growth kinetics of tumors. Clarendon Press, Oxford (1977).

41 Suzuka I, Daidoji H, Matsuoka M, Kadowaki K, Takasaki Y, Nakane PK, Joriuchi T: Gene for proliferating cell nuclear antigen (DNA polymerase-delta auxiliary protein) is present in both manumalian and higher plant genomes. Proc Nat ACad Sci USA 96:3189-3193 (1989).

42 Tan $C K$, Castillo C, So AG, Downey KM: An auxiliary protein for DNA polynnerase delta from fetal calr thymus. IBiol Chem 261:310-316(1986).

43 Tinnemans MMFJ, Schutte B, Lenders M-HJH, Ten Velde GPM, Ramaekers FCS, Blijham GH: Cytokinetic analysis of lung cancer by in vivo bromodeoxyruridine labelling. Br $J$ Cancer" 67:1217-1222(1993).

44 Tinnemans MMFJ, Lenders M-HJH, Ten Velde GPM, Blijham GH, Ramaekers FCS, Schutte B: S-phase arrest of nutrient deprived lung cancer cells. Cytometry 19:326-333 (1995).

45 Tsurusawa M, Fujimoto T: Cell cycle progression and phenotypic modification of Ki67 antigennegative G1-and G2-phase cells in phorbol ester-ireated Molt-4 human leukenia cells. Cylometry 20:146-153 (1995).

46 Tungekar MF, Gatter KC, Dunnill MS, Mason DI: Ki-67 immunostaining and survivall in operable lung cancer. Histopahology 19:545 550 (1991)

47 Ten Velde GPM, Schutte B, Reynders MMJ, Bosman FT, Blijham GH: Cytokinetic analysiss of lung cancer by bromodeoxyuridine labeling of cylology specimens. Cytometry 10:807-810 (1.989).

48 Van Dierendonck JH, Keijzer R, Van de Velde CJH, Comelisse CJ: Nuclear distribution of the Ki67 antigen during the cell cycle: comparison with growth fraction in human breast cancer cells. Cancer Rer 49: 2999-3006 (1989).

49 Van Dierendonck JH, Wijsman JH, Keijzer R, Van de Volde CJH, Comelisse CJ: Cell-cyclerelated staining patterns of anti-proliferating cell nuclear antigen monoclonal antibodics. Am I Parhol 138: 1165-1172(1991).

50 Verheijen R, Kuijpers HJH, Schlingeman RO, Bochner HL, Van Dricl R, Brakenhorf GJ, Ramaekers FCS: Ki67 detects a nuclear matrix associated prolliferation antigen. Part $\mathbb{1}$. Intracellular localisation during interphase. J Cell Sci 92:123-130 (1989).

51 Verheijen R, Kuijpers HJH, Van Driel R, Beck JLM, Van Dierendonck JH, Brakenhoff GJ, Ramackers FCS: $K 67$ detects a nuclear matrix associated proliferation antigen. Part II. Localisation in mitotic cells and association with chromosomes. ofell SCl 92:53)-540 (1989). 
52 Wascen $\mathrm{NH}$, Lanc DP: Monoclonall antbody analysis of the proliferating cell nuclear antigen (PCNA). Structural conscrvalion and the detecion of a nucleolar form. $J$ Cell Sct 96:121-129 (1990).

53 Woods AL, Hall PA, Shepherd NA, Hanby AM, Waseem NH, Lane DP, Levison DA: The assessment of proliferating cell nuclear antigen (PCNA) immunostaining in primary gastrointesinal Jymphomas and its relationship to histological grade, $S+G 2+M$ phase fraction (flow cytometric analysis) atind prognosis. Histopathology 19:21-27 (1991).

54 Yu $\mathrm{CC}$-W, Woods AL, Levison DA: The assessmemt of cellular proliferation by immunohistochemistry: a review of currenty available methods and their applications. Histochem $J 24: 121$. $131(1992)$ 
Methodological aspects of proliferation and cell loss measurements 



\title{
Three Parameter Flow Cytometric Analysis: Simultaneous Detection of Cytokeratin, Proliferation Associated Antigens and DNA content
}

\author{
Bert Schutte, Monique MFJ Tinnemans, Gio FP Pijpers,
}

Marie-Hélène JH Lenders and Frans CS Ramaekers

Depantment of Molecular Cell Biology \& Genetics, University of Limburg and Department of internal Medicine, University Hospital Maastricht. 


\section{Summary}

The analysis of the cell cycle distributions by univariate flow cytometric DNA measurement has been widely applied in the clinic to determine kinetic parameters of human malignancies. A common problem with measurements of cell cycle phase distributions in tumor biopsy material is the presence of non-malignant diploid cells. Furthermore, such a static measurement might not be accurate enough to describe the dynamic process of cell proliferation. For this purpose alternative methods have been developed to include $\mathrm{BrdC}$ incorporation or the presence of intrinsic proliferation associated markers such as PCNA or Ki67-Ag into the analysis. However, the presence of non-malignant diploid cells will influence also these bivariate analyses, especially in case of DNA-diploidy of the tumor cells.

Here we present a three parameter flow cytometric assay based on the simultaneous detection of cytokeratin, DNA and a proliferation associated marker, such as BrdU, PCNA or Ki67-Ag. Based on the presence of cytokeratin, epithelial cells can be selected for a detailed cell cycle analysis. This method can be applied to frozen tissue, which makes this assay useful for multicentre clinical studies.

\section{Introduction}

The analysis of the cell cycle by univariate flow cytometric DNA measurement, either of samples prepared from fresh frozen tissue or from paraffin embedded material, has been applied in the clinic to estimate kinetic parameters of human tumors ${ }^{3,6,10,19}$. The goal of most of these studies has been to correlate cell kinetics and treatment outcome in specific patient groups, with the eventual aim of using such methods prospectively to facilitate the clinician's choice between alternative treatment protocols. In a recent consensus meeting ${ }^{3,6,10,19}$ the outcome of many studies has been reviewed and it was concluded that the measurement of the S-phase fraction (SPF) was in general not conclusive in predicting the prognosis of solid tumors, although in many studies a trend towards a better prognosis of tumors with a low SPF was observed ${ }^{3,6,10}$.

There are two main reasons why cytokinetic data, obtained by univariate DNA measurements, are often not conclusive. Firstly, a common problem with proliferation measurements in tumor (biopsy) material is the admixture of non-malignant diploid cells. To date, algorithms for estimation of cell cycle phase distributions are available, which deal with overlapping histograms. However, in case of DNA-near-diploid tumors these models will fail. Also in case of DNA-diploid tumors the calculated cell cycle phase distributions are often inaccurate, since the frequency and proliferative behavior of normal cells is not accounted for. To overcome this problem of admixture of normal non-epithelial cells, such as infiltrating leucocytes or fibroblasts, in the flow 
cytometric DNA analysis of carcinomas, cytokeratin antibodies are used. Using ethanol fixed cell suspensions, non-epithelial cells could be excluded from the analysis by gating on cytokeratin positive epithelial cells. By application of such immunostaining procedures, low numbers of epithelial cells could be recovered for accurate DNA cell cycle analysis?

Secondly, a static measurement of, for example, cell cycle phase distributions is obviously not accurate enough to describe the dynamic process of cell proliferation. Therefore, methodology has been developed to detect DNA synthesis activity by incorporation of nucleotide analogues such as bromodeoxyuridine $(\mathrm{BrdU})^{18}$. After pulse labeling with BrdU, followed by a chase, calculation of dynamic parameters, such as $S$-phase transit time and potential doubling time, is feasible using a single biopsy ${ }^{4}$. However, in vivo labeling with $\mathrm{BrdU}$ is not always possible due to practical and/or ethical considerations. Therefore, much attention has been paid to the detection of intrinsic proliferation markers such as Ki67 and PCNA. Some immunohistochemical studies already indicate a prognostic advantage for patients with a malignancy with low numbers of PCNA or Ki67-Ag positive cells ${ }^{9,11.15}$. Combined measurement of these markers and DNA content using flow cytometry offers the possibility to study the expression of these markers in relation to the cell cycle phase and ploidy level. However, for some antigens cumbersome and highly specific fixation procedures are described assuring cell cycle phase specific staining. For instance, PCNA immunoreactivity could be detected in an S-phase dependent manner in paraformaldehyde/methanol fixed and lysolecithin permeabilized cells, while with other fixation protocols no cell cycle phase related staining reaction was observed ${ }^{12}$. On the other hand, the Ki67-Ag could be detected after fixation in acetone or in a washless staining procedure as described by Larsen et al. ${ }^{14}$ The last procedure could also be used for the detection of incorporated BrdU, but the sensitivity of this method was too low for analysis of pulse labeled specimens.

Recently, a tricolor flow cytometric staining technique has been described by Begg et al. "to combine cytokeratin staining with bivariate BrdU/DNA analysis. The authors showed that it was feasible to perform a triple cytokeratin/BrdU/DNA staining on ethanol fixed cells using a single laser flow cytometer. However, they came to the conclusion that there were some drawbacks to their approach. For instance, the pepsin method cannot be used for the detection of BrdU. The authors suggested to improve the quality of whole-cel] staining, for example by using other denaturation methods, as long as these did not affect the antigen used as the normal/malignant discriminator.

Here we present a simple and reproducible staining procedure for triple fluorescence on in vitro cultured tumor cells, which enables not only the selection of epithelial cells, based on cytokeratin expression, but also bivariate cell cycle analysis of DNA and proliferation associated markers, such as PCNA and Ki67-Ag. The method is based on the permeabilization of cells by Triton X-100, followed by a short fixation in methanol at $-20^{\circ} \mathrm{C}$, which leaves the cytokeratin filaments of the cytoskeleton intact. The protocol can be adapted for the detection of $\mathrm{BrdU}$ by inclusion of an additional 
histone extraction procedure in cold citric acid using restriction enzymes. We demonstrate that the described method is also applicable to frozen clinical specimens.

\section{Materials and Methods}

\section{Cell lines}

The human non-small cell Jung cancer (NSCLC) cell line MR65, kindly supplied by Dr. Gropp (Philips Universitäts Klinik, Marburg, Germany), was cultured in Eagle's nuinimal essential medium (Gibco, Paisley, Scotland), supplemented with 1\% non essential amino acid solution (Gibco), 1\% glutamine (Serva, Heidelberg, Germany; no. 22942), 1\% HEPES (Gibco), $10 \%$ heat inactivated newborn calf serum (Gibco, $021-6010 \mathrm{M}$ ) and $0.1 \%$ gentamycin (AUV, Cuyck, The Netherlands). Cells were harvested during exponential growth by trypsinization. The human small cell lung cancer (SCLC) cell line NCI-H82, kindly supplied by Dr. Desmond N. Carney (Mater Misericordiae Hospital, Dublin, Treland), was cultured in RPMI-1640 medium (Gibco) supplemented with $1 \%$ non-essential amino acid solution (Gibco), $1 \%$ glutamine (Serva), $10 \%$ heat inactivated newborn calf serum and $0.1 \%$ gentamycin (AUV). Since this cell line grows as floating aggregates a single cell suspension was prepared by pipetting up and down. In some experiments the cell lines were pulse labeled with 10 $4 \mathrm{M}$ BrdU (Serva, Heidelberg, Germany) for $30 \mathrm{~min}$ before harvesting.

\section{Chinical specimens}

From a patient presenting with a large cell lung carcinoma, fresh tumor tissue was collected by surgical resection, snap frozen in precooled isopentane and stored at $-70^{\circ} \mathrm{C}$. After informed consent the patient received intravenous infusion of BrdU (50

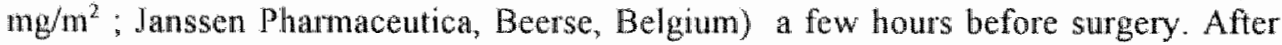
thawing of the tissue in phosphate buffered saline, pH 7.4 (PBS), cell suspensions were made by mechanically mincing the tissue in PBS. Before fixation the suspension was filtered through a $50 \mu \mathrm{m}$ nylon mesh (Stokvis en Smits, Umuiden, The Netherlands).

\section{Antibodies}

The following primary antibodies were used in this study: 1) Mouse monoclonal antibody directed against BrdU (clone IIB5) ${ }^{*}$, available from Euro-Diagnostica BV 
(Apeldoom, The Netherlands), diluted $1: 10 ; 2$ ) Affinity purified rabbit antiserum to cytokeratins ${ }^{17}$, available from Euro-Diagnostica BV, diluted 1:20; 3) Mouse monoclonal antibody PC10 to PCNA, diluted 1:100, was kindly provided by Dr. David Lane (Dundee, UK); 4) Mouse monoclonal antibody MIB-1, directed against the Ki67-Ag, was diluted 1:100. The antibody was kindly provided by Dr. Johann Gerdes (Borstel, Germany); 5) Mouse monoclonal antibody Ki67 (DAKO A/S, Glostrup, Denmark), diluted $1: 10$; 6) Polyclonal rabbit antiserum to Ki67-Ag, kindly provided by Jon Askaa (DAKO A/S), diluted 1:100.

As secondary antibodies we used PhycoErythrin (PE) conjugated goat-anti-mouse Ig

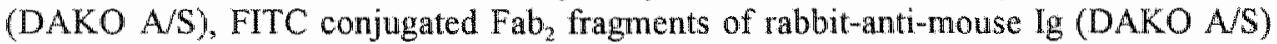
and FITC-conjugated sheep-anti-rabbit $\lg$ (CLB, Amsterdam, The Netherlands), diluted $1: 10,1: 10$ and 1:400 respectively.

\section{Isolation of cells and fixation}

To approximately $10^{6}$ cells in $100 \mu \mathrm{PBS}, 500 \mu \mathrm{l}$ cold lysis buffer, containing PBS, $0.5 \%$ Triton $\mathrm{X}-100,10 \mathrm{mg} / \mathrm{ml}$ bovine serum albumin (BSA; Sigma), $0.01 \mu \mathrm{g} / \mathrm{ml}$ EDTA, pH 7.4, was added. After gentle mixing the samples were kept on ice for 15 min and fixed by adding $3 \mathrm{ml}$ of $-20^{\circ} \mathrm{C}$ absolute methanol. The samples were allowed to stand for $10 \mathrm{~min}$ at room temperature, the cells pelleted for $5 \mathrm{~min}$ at $400 \mathrm{~g}$ and resuspended in $2 \mathrm{ml}$ of cold PBS. After centrifugation the cells were rinsed once in PBS supplemented with $1 \mathrm{mg} / \mathrm{ml} \mathrm{BSA} \mathrm{(PBS/BSA)}$.

\section{DNA denaturation}

For the detection of incorporated BrdU, the protocol described by Dolbeare et al..$^{5}$ was used. Briefly, fixed cells were incubated on ice in $0.1 \mathrm{M}$ citric acid, supplemented with $0.5 \%$ Triton X-100. After rinsing twice in PBS and once in EcoRI buffer ( $50 \mathrm{mM}$ Tris $\mathrm{HCl}_{2} 100 \mathrm{mM} \mathrm{NaCl}, \sqrt{0 \mathrm{mM} \mathrm{MgCl}}, \mathrm{pH} 8.0$ ), 30 units of EcoRl (BRL/GIBCO, Gatesburg, $\mathrm{MD}$ ) were added and the suspension was incubated for $30 \mathrm{~min}$ at $37^{\circ} \mathrm{C}$. The cells were rinsed once in Exolll buffer $(50 \mathrm{mM}$ Tris $\mathrm{Hcl}, 5 \mathrm{mM} \mathrm{MgCl}, 1 \mathrm{mM}$ DTT, pH 8.0) and 30 units of ExollI (BRL/GIBCO) were added. The suspension was incubated for another $30 \mathrm{~min}$ at $37^{\circ} \mathrm{C}$. Before immunocytochemical detection of $\mathrm{BrdU}$ cells were rinsed once in PBS/BSA.

\section{Immunocytochemistry}

To approximately $10^{6}$ fixed cells in $100 \mu \mathrm{I}$ PBS/BSA, appropriately diluted primary antibody was added. For triple staining both primary antibodies were added 
simultaneously, tee the polyclonal cytokeratin antiserum in combination with a monoclonal antibody to one of the proliferation markers. After incubation for $1 \mathrm{~h}$ at room temperature, the cells were rinsed twice in PBS/BSA. For visualization secondary antibody was added in the recommended dilution. For triple staining both secondary antibodies were added simultaneously. After incubation for 45 min at room temperature samples were rinsed twice in PBS/BSA and the cells were finally resuspended in $0.5 \mathrm{ml}$ cold PBS supplemented with $100 \mu \mathrm{g} / \mathrm{ml}$ RNase (Serva) and 1.0 $\mu \mathrm{g} / \mathrm{ml}$ propidium iodide ( $\mathrm{PI}$; Calbiochem, La Jolla, $\mathrm{CA}$ ). The samples were allowed to stand for 15 min on ice in the dark before flow cytometric analysis. For bivariate flow cytometric analysis only FITC-labeled secondary antibodies were used and the PI concentration was increased to $10 \mu \mathrm{g} / \mathrm{mll}$.

The anti-BrdU monoclonal antibody was used as a control antibody for the mouse primary antibodies, except when cells were labeled with BrdU. In this case, the primary antibody was omitted as a negative control. Polyclonal rabbit anti-Von Willebrand Factor (DAKO A/S) was used as a negative control for the cytokeratin antiserum.

To control for cross reactivity of secondary antibodies, either the mouse or the rabbit primary antibody was omitted from the immunocytochemical procedure.

To control for bleed through of the different fluorochromes single FITC, PE or PI stained samples were prepared.

\section{Flow cytometry}

For flow cytometric analysis a FACSort (Becton Dickinson, Sunnyvale, CA) equipped with a single Argon ion laser was used. Exitation was done at $488 \mathrm{~nm}$, and the emission filters used were 515-545 BP (green; FITC), 572-588 BP (orange; PE) and $600 \mathrm{LP}$ (red; PI). A minimum of 10,000 cells per sample were analyzed and data were stored in list mode. FITC and PE signals were recorded as logarithmic amplified data, while the Pl signals were recorded as linear amplified data. For bivariate FITC/PI analysis no compensation was used.

For tricolor analysis the following settings were used: $400 \mathrm{~V}, 405 \mathrm{~V}$ and $350 \mathrm{~V}$ on photomultiplier tubes for FLI (FITC), FL2 (PE) and FL3 (PI), respectively. Compensation for (FL1-\%FL2), (FL2-\%FL1), (FL2-\%FL3) and (FL3-\%FL2), was $0.2 \%, 38.9 \%, 42.8 \%$ and $8.3 \%$, respectively.

Data analysis was performed with the standard Lysis and Cellfit software (Becton Dickinson). As a standard procedure for all analyses, data were gated on pulse processed PI signals to exclude doublets and larger aggregates. 


\section{Confocal scanning laser microscopy}

Cells stained in suspension were put onto glass slides, covered with a coverslip and sealed with nail polish. Slides were analyzed using the MRC 600 confocal scanning laser microscope (Bio-Rad Laboratories, Hemel Hempstead, UK), equipped with an air-cooled Argon-Krypton mixed gas laser and mounted onto an Axiophot microscope (Zeiss, Oberkochen, Germany). The laser scan microscope was used in the dual parameter setup, according to the manufacturer's specification, using dual wavelength excitation at $488 \mathrm{~nm}$ and $568 \mathrm{~nm}$ for FITC and PI, respectively. Emission spectra were separated by the standard sets of dichroic mirrors and barnier filters. All scans were recorded in photon counting mode.

\section{Results}

In order to develop a triple labeling procedure for the simultaneous detection of DNA content, cytokeratins and proliferation associated markers for subsequent multiparameter flow cytometric analysis, several technical issues had to be solved. Amongst these was the assessment of appropriate pretreatment and fixation methods that ensured a cell cycle phase-dependent immunostaining of intrinsic proliferation associated markers. Figure $1 \mathrm{~A}$ shows that the flow cytometric protocol described by Landberg and Roos ${ }^{13}$, which includes a Triton X-100 extraction step, resulted in reproducible PCNA staining of S-phase cells. Also other cellular components remained detectable in cells permeabilized with Triton X-100 and subsequently fixed in cold methanol. Amongst these were cytokeratins (Fig. 1B), Ki67-Ag (Fig. 1C) and incorporated BrdU (Fig. 1D). Coefficient of variation (CV) values for the DNA histograms thus obtained were in the range of $2-4 \%$. Addition of protease inhibitors in the lysis buffer did not show any effect (data not shown).

Since cytokeratins are insoluble in Triton $\mathrm{X}-100$ and remain present around the nucleus after the Landberg protocol, strong cytokeratin immunoreactivity was found in MR65 cells after several incubation and centrifugation steps. To investigate this further, these MR65 cells were submitted to confocal scanning laser microscopy after cytokeratin staining in suspension. In Figure $2 \mathrm{~A}$ a clear filamentous staining pattern can be observed in a projection of images of a stack of confocal planes. Surprisingly, mitotic figures were preserved, as shown in Figure $2 \mathrm{C}$. The condensed chromosomes are kept together in a fine fillamentous cytokeratin network. We also compared cytokeratin expression levels in Triton X-100 extracted MR65 cells with cells that were fixed directly for $30 \mathrm{~min}$ in cold $70 \%$ ethanol (Fig. 3). The resollution of the histograms was comparable for both protocols. There were no indications that in some cells the cytokeratin skeleton was lost. 


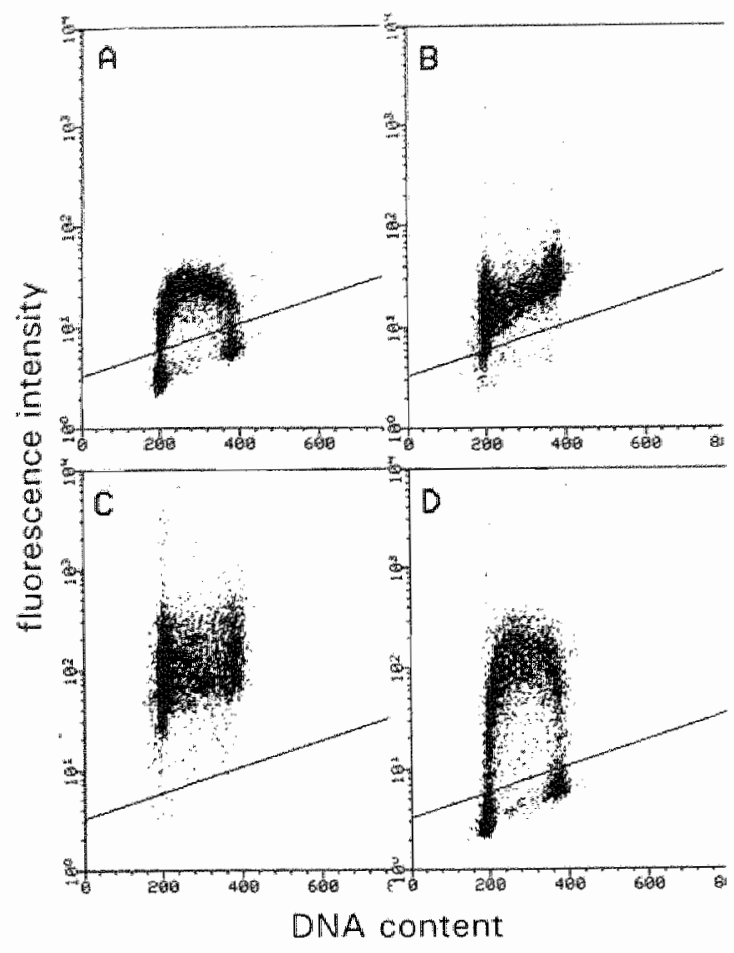

Figure 1. Bivariate analysis of DNA vs. PCNA (A), Ki67 (B), cylokeratin (C) and Brdu (D) in MR65 cells after Triton $X-100$ extraction and fixation in cold methanol. The solid line indicales the threshold for positve immunoreactivity, based on the negative control.

Since the use of proteases, necessary for sensitive detection of BrdU incorporation, will have deteriorating effects on other intrinsic cellular markers, we adapted the protocol for BrdU detection in Triton-X100 extracted, methanol fixed cells and compared it to the standard pepsin method ${ }^{6}$. Inclusion of an EcoR1/ExollI digestion step, preceded by histone extraction, gave a sensitivity comparable to the standard pepsin method. Furthermore, cytokeratin, PCNA and Ki67- Ag immunoreactivity was preserved under these conditions.

For triple labeling of cells in suspension we used the combination of FITC and PhycoErythrin (PE) labeled antibodies in combination with the DNA specific fluorochrome propidium iodide (PI). Since PI gave extensive cross talk in the FL2 (orange) channel, the concentration of the dye was decreased to $0.5 \mu \mathrm{g} / \mathrm{ml}$. Even at this concentration extensive cross talk exists, but this could easily be compensated for. 
A
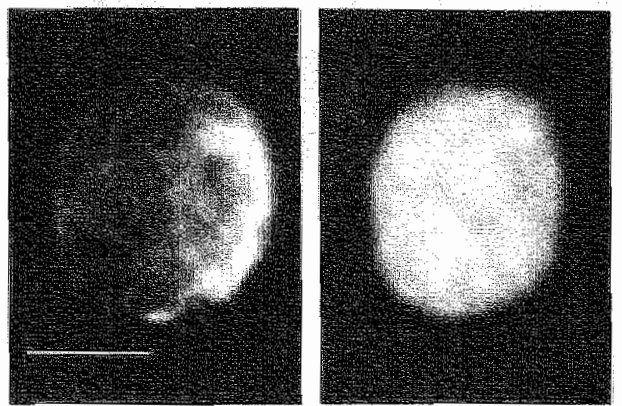

B

C
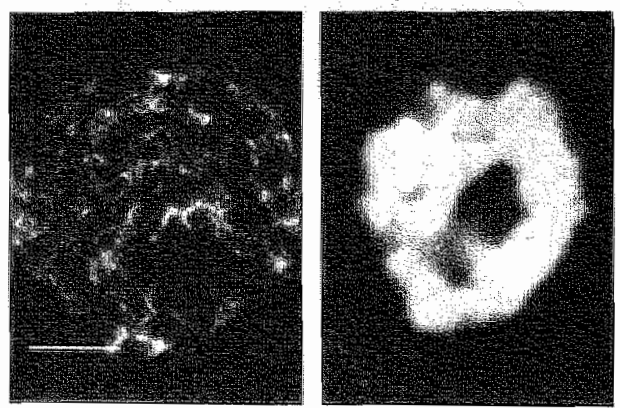

D

Figure 2. A linear projection of a stack of confocal images of an interphase $(A, B)$ and mitotic $(C, D)$ MR65 cell after staining in suspension for cytokeratin $(A, C)$ and DNA $(B, D)$. Note the filamentous cytokeratin staining in both the interphase and the mitotic cell.
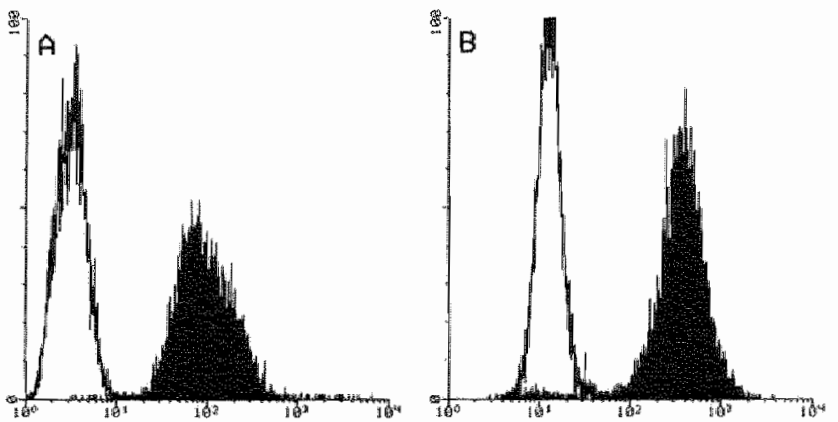

\section{fluorescence intensity}

Figure 3. Fluorescence histograms of anti-cytokeratin (shaded area) and control (unshaded area) sera in MR65 cells after Triton X 100 extraction and fixation in methanol (A) and after ethanol fixation of wital cells (B). Note that the relative fluorescence intensities of both staining pratocols are comparable and that the background fluorescence after Triton $X$ - 100 extraction and subsequent fixation in methanol is reduced. 


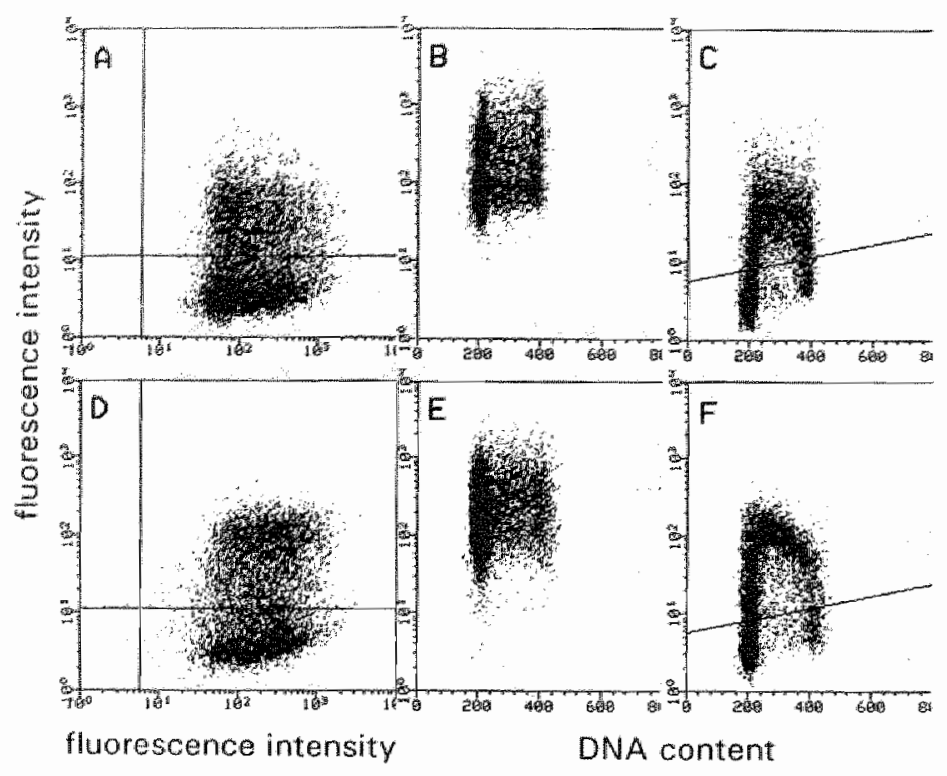

Figure 4. Trivariate analyses of cytokeratin/BrdU/DNA (A-C) and cytokeratin/PCNA/DNA (D-F) of MR65 cells. Panels $A$ and D show dotplots of cytokeratin ( $x$-axis) vs. BrdU and PCNA ( $y$-axis), respectively. Panels $B$ and $E$ depict cytograms of DNA ( $x$-axis) vs. cytokeratin ( $y$-axis), while in panels $C$ and $F$ cytograms of DNA ( $x$-axis) vs. BidUl or PCNA ( $y$-axis) are shown, respectively. The solid lines in panels $A, C_{y} D$ and $F$ denote the thresholds for immunoreactivity as determined based on the negative controls.

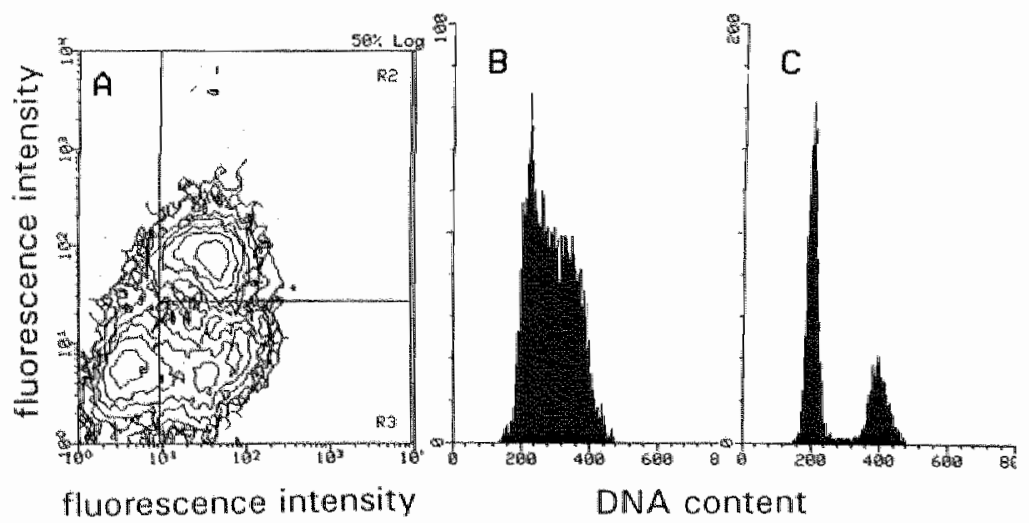

Figure 5. Trivariate PCNA/Ki67/DNA analysis of MR65 cells. Panell A depicts a bivariate contour plot of Ki67 (x-axis) ws. PCNA ( $y$-axis) immunofluorescence. Cells from region 2 (Ki67-Ag+JPCNA+) are predominantly in the $S$-phase of the cell cycle (B), while region 3 (Ki67-Ag+/PCNA-) is composed of $\mathrm{G}_{1}-$ and $\mathrm{G}_{2} / \mathrm{M}$ phase cells (C). 


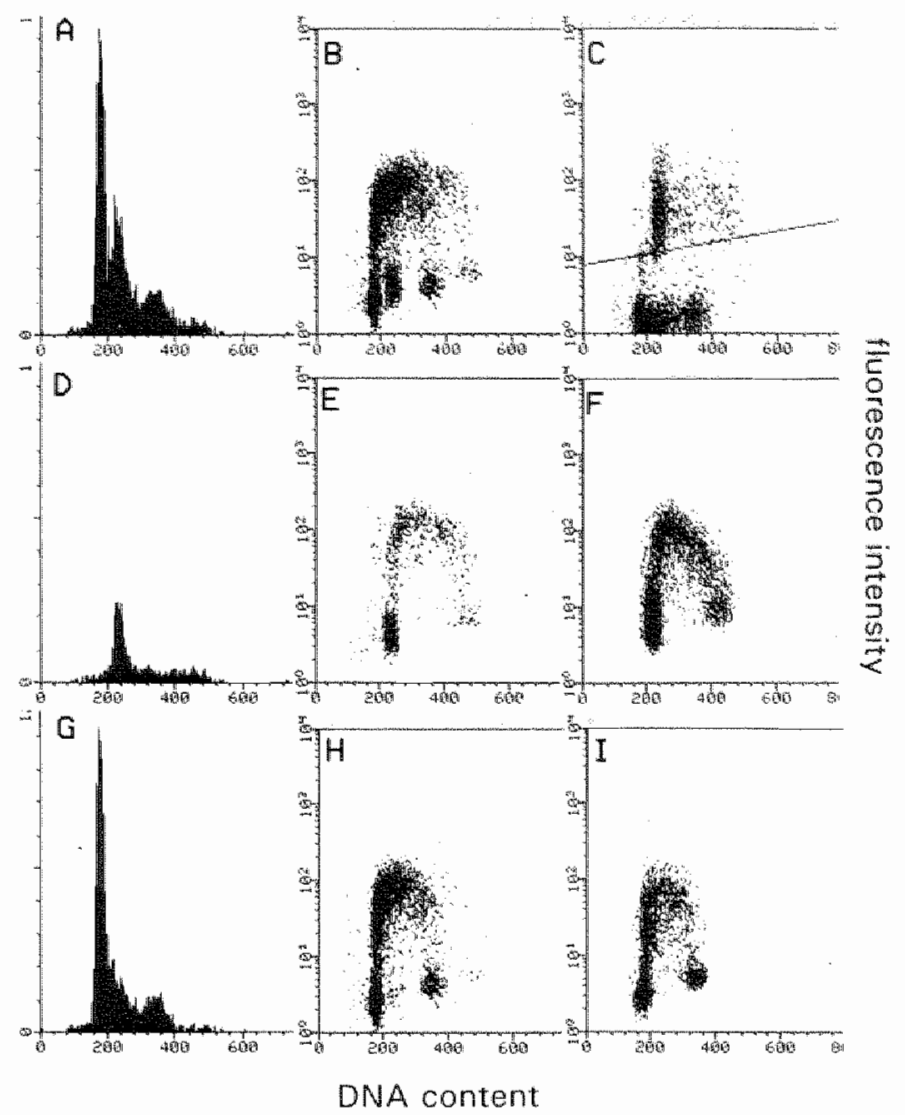

Figure 6. Trivariate cytokeratin/PCNADNA analysis of a mixture of NCI-H82 cytokeratin-negative SCLC cells and cytokeratin-positive MR65 NSCLC cells. Panel A shows the DNA histogram of the ungated cells, while in panels $B$ and $C$ the dotplots of DNA ( $x$-axisy) vs. PCNA ( $y$-axis) and DNA ( $x$-axis) vs. cytokeratin (y-axis) of the same cells are depicted, respectively. Panels $D$ and $E$ show the DNA histogram and the dotplot of DNA (x-axis) vs. PCNA (y-axis) after gating on cytokeratin posilive calls. The DNA histogram and the cytogram of DNA ( $x$-axis) wS. PCNA ( $y$-axis) of the cytokeratin negative cells are depicted in panels $G$ and $H$, respectively. After gating on cylokeratin immunoreactivity the populations of cells with the different DNA indices were completely resolved (compare panelis $A, D, G$ ). The same was observed for the bivariate PCNAJDNA distributions (compare panels $B, E, H$ ). Furthermore, these bivariate DNA ( $x$-axis) vs. PCNA (y-axis) distribution patterns were identical to the patterns obtained after double labeling of the separate cell lines (panells $F, I)$.

The quality of the DNA histograms thus obtained was still acceptable with CVs ranging from $4-6 \%$. For all trivariate analyses no cross reactivity of secondary antibodies was observed (data not shown). Examples of trivariate cytokeratin/BrdU/DNA and 
cytokeratin/PCNA/ONA analyses in MR65 cells are depicted in Figure 4 . It is obvious from Figures $4 \mathrm{~B}, \mathrm{C}, \mathrm{E}$ and $F$ that the cell cycle specific staining patterns for $\mathrm{PCNA}$ and BrdU retain an acceptable resolution, comparable to the results of a bivariate analysis (of. Fig. 1). Simultaneous detection of the two intrinsic nuclear markers Ki67-Ag and PCNA shows that all S-phase cells were positive for both PCNA and Ki67-Ag (Fig. 5). Furthermore, $\mathrm{Ki67-Ag}$ positive and PCNA negative cells were located in either $\mathrm{G}_{2} / \mathrm{M}$ or $\mathrm{G}_{1}$, while double negative cells were almost exclusively located in the $\mathrm{G}_{1}$ phase of the cell cycle. A minor fraction of PCNA positive, Ki67-Ag negative cells was located in the $G_{1}$-phase of the cell cycle.

To be of practical value in the analysis of clinical specimens, the protocol must allow the recognition of minor subpopulations of cells based on the presence of cytokeratin. Furthermore, a more detailed cell cycle analysis of these subpopulations should be possible. Therefore, an experiment was performed in which $\mathrm{NCI}-\mathrm{H} 82$ cells, which do not contain cytokeratin and have a DNA index of 1.2 , were mixed with the cytokeratin positive MR65 cells, which have a DNA index of 1.55. Both cell lines were analyzed. separately and as mixtures in trivariate cytokeratin/PCNADDNA analyses. Figure 6 shows that both cell populations, when mixed in a $3: 1$ ratio, could be analyzed separately by gating on cytokeratin expression (Figs. $6 \mathrm{D}, \mathrm{G}, \mathrm{E}, \mathrm{H}$ ). The number of PCNA positive cells measured in this mixture was $47.1 \%$ and $52.9 \%$ for MR65 (Fig. $6 \mathrm{E}$ ) and NCL-H82 cells (Fig. $6 \mathrm{H}$ ), respectively. These percentages were comparable to

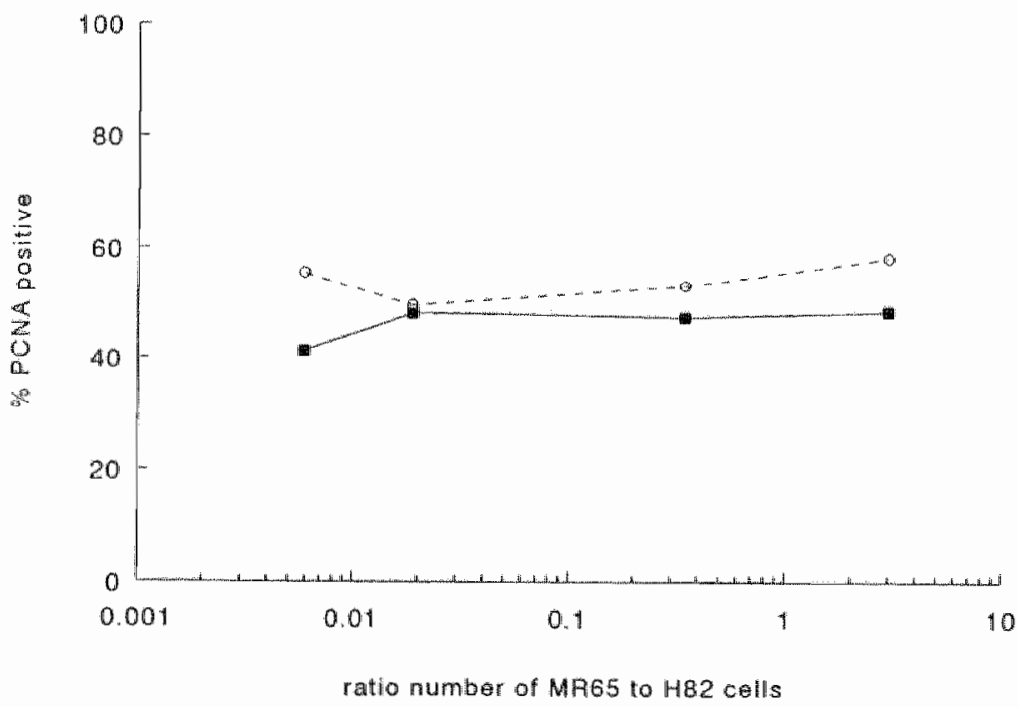

Figure 7. The number of PCNA-positive cells in MR65 (solid squares) and $\mathrm{NCl}-$ $\mathrm{H} 82$ (open circles) cells after gating on cytokeratin-positive and cytokeratin-negative cells, respectively, in mixtures of different ratios. 

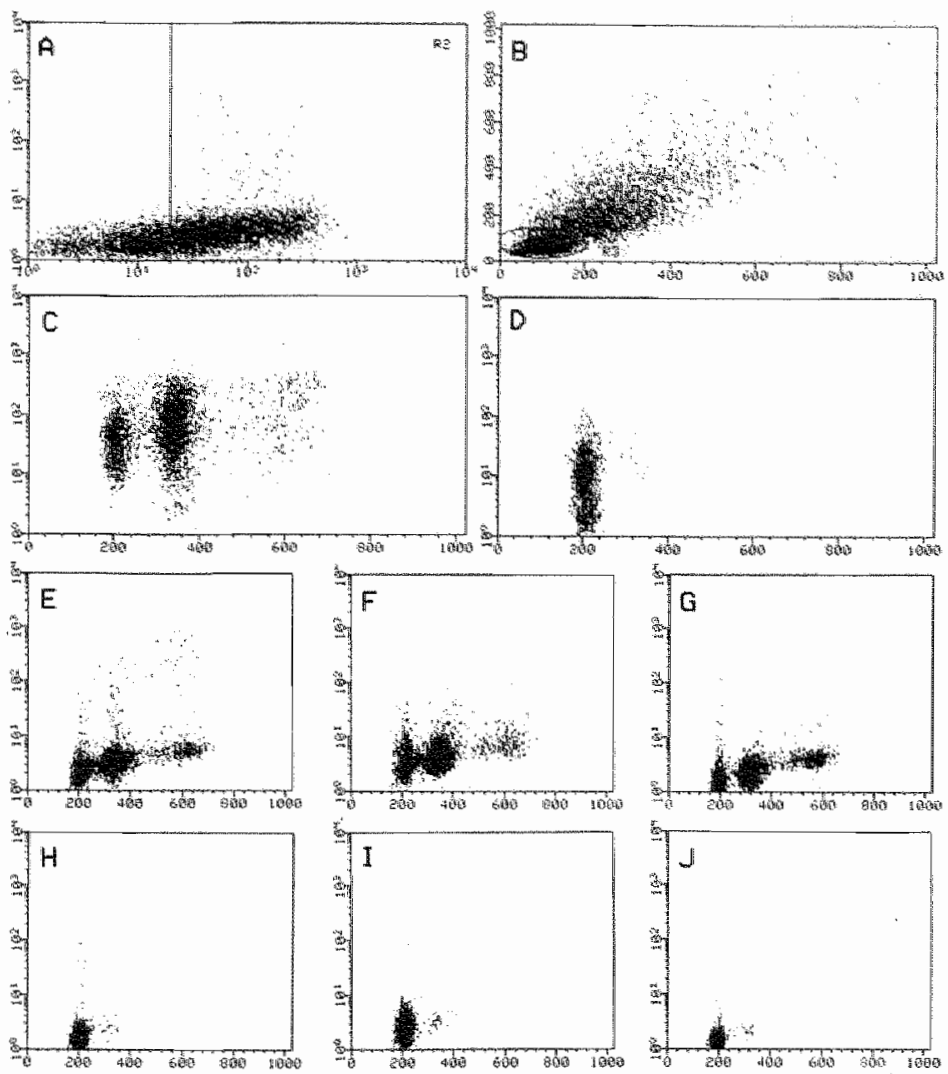

Figure 8. An example of a detailed cell cycle analysis using multi parameter flow cytometry on a frozen DNA aneuploid lung tumor. The tumor was in vivo labeled with BrdU and chased for $4.5 \mathrm{~h}$. Colls were stained in suspension for cytokeratin, prolferation associated markers (Ki67-Ag E,H; PCNA F, I; BrdU $G_{z} J$ ) and DNA. Panel A shows a dotplot of cytokeratin ( $x$-axis) vs. Ki67-Ag (y-axis). The majority of Ki67$\mathrm{Ag}$ positive cells is found in the cytokeratin positive fraction. Furthermore, when cells were gated basied on size characteristics, as depicted in region 3 in the cytogram of forward ( $x$-axis) vs. side scatter ( $y$-axis) in panel $B$, it appeared that the small sized cells from region 3 contained predominantly DNA-diploid, cytokeratin-negative cells as is shown in the dotplot of DNA (x-axis) vs. (cytokeratin $(y-a x i s)$ in panel D. The large sized cells outside region 3 were enriched for DNA aneuploid, cytokeratin-positive cells as is evident from the DNA ( $x$-axis) vs. cytokeratin (y-axis) cytogram in panel $C$. Dotplots of DNA ( $x$-axis) ws. antigen (y-axis) are shown for the large sized, cytokeratin-positive cells ( $E$-G) and for the small sized, cytokeratin-negative cells $(\mathrm{H}-\mathrm{J})$. The intrinsic proliferation associated antigens, i.e. Kib7-Ag $(\mathrm{E}, \mathrm{H})$ and PCNA $(F, \|)$ showed the characteristic cell cycle specific staining pattems. The BrdUlupositive cells $(G, J)$ were located in $G_{1}$, late $S$ and $G_{2} M$ phase of the cell cycle, as to be expected after a chase period of $4.5 \mathrm{~h}$. 
those obtained in the separate cell lines, i.e. $43.7 \%$ for MR65 (Fig. 6F) and $43.6 \%$ for NCI-H82 cells (Fig. 6I). The PCNA labeling index did not significantly change for the individual cell lines when the ratio between NCl-H82 and MR65 cells was increased up to $1: 200$ (Fig. 7).

To demonstrate that the presented method is indeed applicable to clinical specimens, trivariate flow cytometric analyses were performed on frozen, unfixed lung cancer specimens. Figure 8 shows that based on the selection for cytokeratin expression and scatter characteristics a detailed cell cycle analysis can be performed on the epithelial (tumor) cells. When cells were gated based on scatter characteristics (Fig. 8B), it appeared that the cytokeratin positive fraction was found in the large sized cells (Fig. 8C), while the small sized cells were predominantly negative for cytokeratin (Fig. 8D). Furthermore, the DNA-aneuploid fraction was enriched in the large sized cells and absent in the small sized cells. By gating on both scatter characteristics and cytokeratin expression, the number of cells positive for Ki67-Ag (Figs. 8 E, H), PCNA (Figs. $8 \mathrm{~F}, \mathrm{l}$ ) and BrdU (Figs. $8 \mathrm{G}, \mathrm{J}$ ), were analyzed in the large sized, cytokeratinpositive fraction (Figs. $8 \mathrm{E}-\mathrm{G}$ ) and in the small-sized, cytokeratin negative fraction (Figs. $8 \mathrm{H}-\mathrm{J}$ ) separately. The numbers of positive cells in the DNA-aneuploid fraction were $9.3 \%, 2.7 \%$ and $3.2 \%$ for $\mathrm{Ki} 67-\mathrm{Ag}, \mathrm{PCNA}$ and $\mathrm{BrdU}$, respectively. The number of positive cells in the small sized, cytokeratin-negarive population did not exceed background levels. For both Ki67-Ag and PCNA a cell cycle specific staining was noted, while BrdU-positive cells were found both in the $G_{1}$, late $S$ and $G_{2} / M$ phase of the cell cycle. This could be accounted for by assuming that these cells have progressed through the cell cycle during the chase period after pulse labeling.

\section{Discussion}

Many attempts have been undertaken to measure prollferative characteristics of malignancies using flow cytometry and to correlate the outcome with the response to treatment or patient survival ${ }^{3,10.19}$. However, these measurements are hampered by a common methodological problem, i.e. the inability to correct for the presence of nomal cells in the biopsy. Even after application of protocols that include the simultaneous detection of DNA content and the presence of cytokeratins to gate out non-epithelial cells, it is questionable whether a static measurement of cell cycle phase distributions accurately describes the proliferative characteristics of a tumor. Evidence is accumulating that cells can arrest at other phases than the $\mathrm{G}_{1}-$ or $\mathrm{G}_{0}$-phase of the cell cycle ${ }^{21,24}$. For instance, using the BrdU incorporation assay, unlabeled S-phase cells have been described by several authors 2820,2 . The presence or absence of intrinsic proliferation associated markers, such as PCNA or Ki67-Ag, might therefore give additional infomation. It is known that PCNA is tightly associated with the replication complex of actively DNA-synthesizing cells and that its cell cycle phase specific 
presence can be detected after appropriate cell fixation. Also the presence of the Ki67. $\mathrm{Ag}$ is characteristic for actively cycling cells $\mathrm{s}^{22}$. However, absence of $\mathrm{Ki} 67-\mathrm{Ag}$ is not conclusive, since it has been reported that during nutrient deprivation, Ki67-Ag expression is rapidly lost, while cells are still able to complete the cell cycle ${ }^{23}$.

In this study we have presented a three-color staining protocol that is based on the fixation and staining procedure for bivariate PCNADNA staining as originally described by Landberg and Roos ${ }^{13}$. This protocol allows detailed cell cycle analysis of epithelial cells in heterogeneous mixtures of infiltrating normal cells and tumor cells.

Cell cycle specific detection of different proliferation associated antigens was possible with the presented protocol. For instance, PCNA is an auxillary protein for DNApolymerase $\delta$ and it is present in the nucleus during the whole cell cycle because of its rather long half life. On form is easily extractable with mild detergent treatment or fixation with alcohol based fixatives. The other form of PCNA is tightly bound to the replication complex during S-phase of the cell cycle and can only be removed from the nucleus after extraction in high salt. In the described protocol, only the replication complex associated form is retained in the nuclei of cells.

In cell lines both the polyclonal and monoclonal antibodies to Ki67-Ag gave strong cell cycle specific staining under the conditions described in the Materials and Methods. However, only the monoclonal MIB-1 antibody gave strong immunolluorescence in clinical specimens incubated under the same conditions, while the other sera gave negative results.

The eytokeratin cytoskeleton remained intact after lysis, fixation and staining of the cells in suspension. Even the fragile mitotic cells could withstand the treatment. Furthermore, there were no indications that the cytoskeleton was lost in a subpopulation of cells, since the percentage of cytokeratin positive cells as determined by flow cytometry was identical as compared to that after ethanol fixation and staining of whole cells. The advantage of the presented method is that either the accessibility of the antibodies to the antigens is increased or aspecific background staining is greatly reduced as shown for the cytokeratin staining. A disadvantage of the technique is that soluble, mostly small molecular weight, cytoplasmic components are specifically lost during lysis of cells.

Given the fact that the cytoskeleton remained intact, cytokeratin expression can be used as a marker to exclude non-epithelial cells, such as fibroblasts and leucocytes, from the analysis. By combining cytokeratin expression and e.g. staining for BrdU, a detailed cytokinetic analysis of the remainder of epithelial cells is possible, while also the DNA index and cell cycle distribution of these cells can be established Recently, a technique has been described by Pollack et al "that enables the cytokinetic analysis of a heterogeneous population of cells based on double labeling of cells with two halogenated nucleotides. However, this method requires the administration of two labels separated in time. Similar results can, however, also be obtained by using only one extrinsic label in combination with PCNA expression as the secondary label. The method described in this paper allows the simultaneous detection of both antigens. 
The presented method is not only useful for in vitro cultered cell lines, but is also applicable to fresh and even frozen tissue samples. This would obviate the need for the direct preparation of cell suspensions, making the method suitable for detailed multicentre studies on the significance of proliferative characteristics of tumors in relation to clinical behavior.

\section{Acknowledgements}

The authors are grateful towards dr. J. Askaa, dr. \$. Gerdes and dr. D. Lane for kindly supplying the antibodies used in this article. This tesearch was financially supported by the Dutch Cancer Society. 


\section{References}

1 Begg $\mathrm{AC}$, Hofland $\mathrm{I}$ : Cell kinctic analysis of mixed populations using threc-color fuorescence now cytometry. Cyrometry 12:445-454 (1991).

2 Baisch $H_{3}$, Otto $\mathrm{U}$ : Intratumoral heterogeneity of $S$ phase transition in solid lumours determined by bromodeoxyuridine labelling and flow cylonetry. Cell Prolif 26:439.448 (1993).

3. Bauer KD, Bagwell B, Giaretti W, Melamed M, Zarbo RU, Witzig TE, Rabinowitch PS: Consensus review of the clinicat utilty of DNA fow cytometry in colorectal cancer. Cytonetry $14: 486-491(1993)$.

4 Begg AC, MoNally NJ, Shrieve DC, Karcher H: A method to measure the duration of DNA synthesis and the potential doubling time from a single sample. Cyometry $6: 620 \cdot 626(1985)$.

5 Dolbeare F, Gray IW: Use of restriction endonucleases and Exonuclease IIt to cxpose halogenated pyrimidimes for immunochemical staining. Cyromery 9:631-635 (1988).

6 Duque RE, Andreef M, Braylan RC, Diamond LW, Peiper SC. Consensus review of the clinical utility of DNA flow cytometry in neoplastic hematopathology. Cyometry 14:492-496 (1993).

7 Feitz WF, Beck HLM, Smeets AWGB, Debruyn FMJ, Vooijs GP, Herman CJ: Tissue specific markers in flow cytometry of urological cancers: cytokeratins in bladder carcinoma. Int $J$ Cancer $36: 349-356(1985)$

8 Foster G, Cooke TG, Cooke LD, Stanton PD, Bowie G, Sicl PM: Tunor growth rates in squamous carcinoma of the head and neck measured by in vivo bromodeoxyuridine incorporation and flow cytometry. Br $/$ Cancer 65:698-702 (1992)

9 Gasparini $G$, Boracchi $P$, Verderio P, Bevilacque P: Coll kinelics in human breast cancer: comparison between the prognostic value or the cylofluorinctric S-phase fraction and that of the antibodies to Ki-67 and PCNA antigens detected by immunocy tochemistry. Int J Cancer 57:822. $829(1994)$.

10 Hedley DW, Clark GM, Connelisse CJ, Killander D. Kute T, Merkerl D Consensus review of the clinical utility of DNA cytomely in carcinoma of the breast. Cytometry 14:482-485 (1993).

11. Henriksen R, Strang P, Backstrom T, Wilander E, Tribukat B, Oberg K: Ki-67 inmunostaining and DNA flow cytometry as prognostic factors in cpithelial ovarian cancers. Anticancer Res 14:603-608 (1994).

12 Kurki $P$, Ogata $K$, Tan EM: Monoclonal anibodies to proliferating cell muclear antigen (PCNA)/cyclin as probes for proliferating cells by immunofluorescence microscopy and fow cytometry Immat Methods 109:49-59(1988).

13 Landberg $G$, Roos $G$ : Flow cytometric analysis of proliferation associated nuclear anligens using washless staining of unfixed cells. Cyomety 13:230-240 (1992).

14 Larsen JK, Christensen IJ, Chistiansen J, Mortensen B. Washless double staining of unlixed nuclei for flow cytometric analysis of DNA and a auclear antigen (K6 67 or bromodeoxyuridine). Cyrometry 12:429-437 (1991).

15 Miller TP, Grogan TM, Dahlberg S, Spier CM. Bramiel RM, Banks PM, Foucar K, Kjeldsberg $C R$, Lewy $N$, Nathwani BN at al: Prognostic significance of the Ki-67-associated proliferative antigen in agressive non-Hodghin's lymphomas: a prospective Southwest Oncology Group trial. Blood 83: 1460-1466 (1994).

16. Pollack A, White RA, Cao S, Mcistrich ML, Torry $N H$ Calculating potential doubling time using monoclonal antibodics specific for two halogenated thymidine analogues. Int I Radiat Oncol Brol phys 27:1131-1139(1993) 
17 Ramackers PCS, Puts JJG, Moesker $O$, Kant $A$, Jap PHK, Vooijs GP: Demonstration of Keratin in human adenocarcinomas. Aw J Pah 111:213-223 (1983).

18 Schute B, Reynders MMJ, wan Assche CLMVJ, Hupperets PSGJ, Bosman FT, Blijham GH: An improved method for the immunocytochemical detection of BrdU labeled nuclei using flow cytometry. Cylometry 8:372-376 (1987).

19 Shankey TV, Kallionieni OP, Koslowski JM, Lieber ML, Mayal BH, Miller G, Smith G: Consensus review of the clinical utility of DNA content cytometry in prostate cancer. Cytometry $14: 497-500(1993)$.

20 Ten Velde GPM, Schulte $B_{3}$ Reynders MMJ, Bosman FT, Blijham GH: Cytokinetic analysis of lung tumor cancer by bromodeoxyuridine labeling of cytology specimens. Cytometry 10:807-810 $(1989)$.

21 Tinnemans MMFJ, Lenders MHJH, ten Velde GPM, Blijham GH, Ramaekers FCS, Schutte B: S-phase arrest of nutrient deprived lung cancer cells. Cytomery 19:326-333 (1995).

22 Van Dierendonck JH, Keijzer R, van de Velde C.H, Comelisse Cl: Nuclear distribution of the Ki67 antigen during the cell cycle: Comparison with growth fraction in human breast cancer cells. Cancer Res 49:2999-3006 (1989).

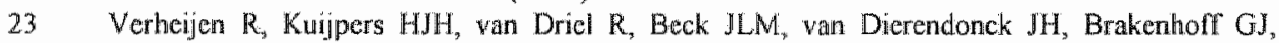
Ramackers FCS: Ki67 detects a nuclear matrix associated proliferation-related antigen. J Cell Sci $92: 531-540(1989)$.

24 Wei W, Nurse P, Brock D: Yeast cells can enter a quiescent state through G1, S, G2 or M phase of the cell cycle. Cancer Res 53:1867-1870 (1993).

25 Wilson GD, McNally NJ, Dunphy $\mathbb{E}_{*}$ Karcher $H$, Pfragner $R$. The labelling index of human and mouse tumours assessed by bromodeoxyuridine staining in vitro and in vivo and flow cytometry. Cyrometry 6:641-647(1985). 


\section{S-Phase arrest of nutrient deprived lung cancer cells}

Monique MFJ Tinnemans, Marie-Hélène JH Lenders, Guul PM ten Velde. Geert H Blijham, Frans CS Ramaekers and Bert Schutte

Department of Molecular Cell Biology \& Genetics, University of Limburg: Departments af Internal Medicine and Pulmonology, University Hospital Maastricht; Department of Internal Medicine, University Hospital Uirecht. 


\section{Summary}

The human small cell lung cancer cell line $\mathrm{NCl}-\mathrm{H} 82$ was used to study the effect of nutritional status on cell proliferative parameters. Incorporation of bromodeoxyuridine (BrdU) was used to characterize actively proliferating cells and to obtain information on cell cycle dynamics. During several days, in which the culture medium was not changed, a gradual decrease in overall cell growth, labeling index and vitality was observed. Simultaneously, an increase in the number of S-phase cells that did not incorporate BrdU was noticed. From a more detailed kinetic study on day 6 of nutrient depletion, it appeared that, although the cells incorporated BrdU, they stopped cycling. When the same cells were regrown in fresh culture medium, a delay of $10 \mathrm{~h}$ in $\mathrm{G}_{1}$-phase entry and exit was measured. After this delay the cells resumed the cell cycle at normal phase transit rates. In addition, BrdU unlabeled S-phase cells were gradually lost from the culture. Bivariate flow cytometric DNA/proliferating cell nuclear antigen (PCNA) and DNA/Ki67-antigen analyses confirmed a delay in $\mathrm{G}_{1}$ phase entry and exit. In this paper we show that nutrient depletion can cause cell cycle arrest as indicated by the occurrence of BrdU unlabeled S-phase cells. This arrest could lead to overestimation of kinetic parameters such as $S$-phase transit time $\left(T_{s}\right)$ and potential doubling time $\left(\mathrm{T}_{\text {poo }}\right)$ as determined after in vivo labeling of tumors.

\section{Introduction}

Flow cytometric studies of cytokinetic properties of lung tumors, using incorporation of the thymidine analogue bromodeoxyuridine (BrdU) as a marker for DNA synthesis activity, have shown the existence of so-called unlabeled S-phase cellis $\mathrm{s}^{19,21}$. These cells, which have an S-phase DNA content and were therefore expected to synthesize DNA, had apparently lost the ability to incorporate BrdU. The observation of an unlabeled S-phase fraction (USPF) was a general phenomenon in diploid as well as in aneuploid lung tumors.

Two different explanations seem plausible for the occurrence of these unlabeled Sphase cells. First, the BrdU may not have been able to reach the cycling cells, due to poor diffusion throughout the tissue. Second, if diffusion is not hampered, the cells might have been arrested in S-phase. Recently, White ${ }^{23}$ addressed this issue in a theoretical model using the bivariate BrdU/DNA analysis model. When inadequate diffusion is the cause of unlabeled S-phase cells, the labeled cells are not expected to be affected in their progression through the cell cycle. In contrast, when cell arrest in S-phase would be the cause, arrest must also be evident from the BrdU labeled cell population, when chased for a limited period of time. The basic principle would be that cell arrest in S-phase occurs randomly in time and therefore cells either remain 
unlabeled when the BrdU is applied, or they incorporate the label and some will arrest during the period of chase. As a consequence, the calculated S-phase transit time will be increased.

In order to investigate whether the presence of unlabeled $S$-phase cells could be due to cell arrest in S-phase, we used a model system in which tumor conditions were mimicked by submitting a lung tumor cell line in vitro to nutritional depletion for several days. During the deprivation period samples were taken to measure the fraction of unlabeled S-phase cells and the S-phase transit time. At day 6 of depletion, when the majority of cells was still viable, we investigated whether this arrest in Sphase was reversible. To this end, depleted and repleted cultures were submitted to a detailed cell kinetic analysis using the BrdU pulse-chase method as described by

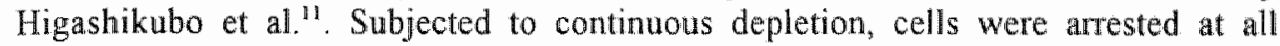
phases of the cell cycle. However, after changing the old medium and culturing in fresh medium, we observed for the $G_{1}$-phase of the cell cycle 1) a delay in cell transit (either out or into $G_{1}$-phase) and 2 ) an unchanged rate of cell transit compared to exponentially growing control cultures. In contrast, the S-phase transit was not delayed, but showed a decreased cell transit rate. Furthermore, from the calculated corrected labeling indices it was evident that unlabeled cells were selectively lost from the culture. In addition, bivariate analysis of DNA and the expression of two proliferation-associated proteins, $\mathrm{Ki} 67-\mathrm{Ag}$ and proliferating cell nuclear antigen (PCNA), confirmed a delayed $\mathrm{G}_{1}$-phase entry and exit.

\section{Materials and Methods}

\section{Cell line and normal culture conditions}

For all experiments, the variant-type small cell lung cancer cell line NCL-H 182 was used. NCI-H82 is a rapidly growing cell line with a doubling time of approximately 24 h. NCI-H82 cells do not adhere to the culture plastic but grow as cell aggregates in suspension. The cells were grown in Hepes-buffered RPMI 1640 medium (Flow, ICN Biomedicals, Costa Mesa, CA) supplemented with $10 \%$ bovine serum product (BSP) (Fetal Clone 1, Logan, UT), $2 \mathrm{~mm}$ glutamine and $0.1 \%$ gentamycin. The cells were kept in an exponential growth state by changing the medium every other day.

\section{Nutrient depletion}

Exponentially growing cell aggregates were harvested and a single cell suspension was prepared by gently pipetting the cells up and down. Cells were counted and 
seeded into $25 \mathrm{~cm}^{2}$ culture flasks at a density of $10^{6}$ vital cells per flask. During the experiment, the medium was not changed for 9 days. The control culture was kept in an exponential growth state.

\section{Brdu pulse chase}

Nutrient depleted cultures were pulse labeled every day for $30 \mathrm{~min}$ with $10 \mu \mathrm{M} \mathrm{BrdU}$ (Serva 15240, Heidelberg, Germany). After washing twice with prewarmed phosphate buffered saline (PBS), the cells were counted and the vitality was determined by trypan blue exclusion. One part of the cells was used for flow cytometric analysis, while the other part of the cell suspension was used for immunocytochemical analysis. A similar series of cells were pulse labeled and then chased in depleted culture medium, obtained from a parallel culture. At $\mathrm{t}=0,4$ and $10 \mathrm{~h}$ cells were harvested.

For detailed cell kinetic analysis, 6 days starved cultures were pulse labeled in either depleted medium or fresh medium and chased for $24 \mathrm{~h}$ in depleted or fresh medium, respectively. The depleted medium from one culture was used to chase the other. Every hour a sample was taken for flow cytometric DNA/BrdU analysis according to Higashikubo et al. ${ }^{11}$ Additionally, every $3 \mathrm{~h}$ a sample was taken for bivariate flow cytometric DNA/PCNA and DNA/Ki67-antigen analysis.

\section{Immunocytochemistry}

PCNA. Approximately $1 \times 10^{4}$ cells in standard culture medium supplemented with $10 \% \mathrm{BSP}$ were cytocentrifuged onto glass slides. After drying for at least $12 \mathrm{~h}$, the slides were fixed in cold methanol $\left(-20^{\circ} \mathrm{C}\right)$ for $10 \mathrm{~min}$, rinsed immediately in PBS and incubated for 1 h at $37^{\circ} \mathrm{C}$ with human anti-PCNA (lot H15, Biolab, Limal, Belgium) diluted 1:40 in PBS containing 0.1\% bovine serum albumin (BSA) (no. A-7030, Sigma, St. Louis, MO). The slides were then washed 3 times in PBS followed by incubation with fluorescein isothiocyanate (FITC)-conjugated rabbit-anti-human $\mathrm{F}(\mathrm{ab})_{2}$ (CLB, Amsterdam, The Netherlands), diluted 1:100 in PBS/BSA. After 45 min of incubation at room temperature, the slides were washed again and the fluorescence signal was intensified by incubation with FTTC-conjugated sheep-anti-rabbit Ig (CLB), diluted 1:100 in PBS/BSA. After washing and counterstaining of the DNA with DAPI, the cells were screened for PCNA positivity using an epifluorescence microscope (Axiophot, Zeiss, Oberkochen, Germany). Only cells with an S-phase specific granular pattern in the nucleus were considered $\mathrm{PCNA}$ positive, according to Bravo and Macdonald-Bravos.

BrdU. Cytospin preparations were made and fixed as described above. The DNA was denaturated by incubation in $2 \mathrm{~N} \mathrm{HCl}$ for 30 min at $37^{\circ} \mathrm{C}$, followed by 5 washing steps in PBS. Cytospin preparations were then incubated for $1 \mathrm{~h}$ at $37^{\circ} \mathrm{C}$ with monoclonal 
anti-BrdU antibody (clone $1165^{17}$ ), appropriately diluted in PBS/BSA. After washing twice in PBS, primary antibody binding was visualized by incubation with FITCconjugated rabbit-anti-mouse $\mathbb{F}\left(a^{\prime}\right)_{2}$ (code F313, DAKO A/S, Glostrup, Denmark) diluted 1:20 at room temperature. After washing and counterstaining of the DNA with DAPI, the cells were screened for BrdU positivity.

Ki67-antigen. Cytospin preparations were made as described above. The slides were fixed in ice-cold acetone for $10 \mathrm{~min}$, immediately rinsed in PBS, and incubated for $1 \mathrm{~h}$ at $37^{\circ} \mathrm{C}$ with $1: 5$ diluted anti-Ki67 (code M722, DAKO A/S). After rinsing twice in $\mathrm{PBS}$, the slides were incubated for $45 \mathrm{~min}$ with $\mathrm{FITC}$-conjugated rabbit-anti-mouse $\mathrm{F}\left(\mathrm{ab}^{\prime}\right)_{2}$ (code $\mathrm{F} 313$, DAKO A/S) diluted 1:20 at room temperature. After washing in PBS and counterstaining of the DNA with DAPI, the cells were screened for antiKi67-antigen immunoreactivity.

Double staining for flow cytometry. Samples for $\mathrm{DNA} / \mathrm{BrdU}$ double staining were fixed in $70 \%$ ice cold ethanol during $30 \mathrm{~min}$ and further processed according to the protocol described by Schutte et al. ${ }^{17}$ Briefly, after rinsing twice in PBS, the samples were digested with $0.4 \mathrm{mg} / \mathrm{ml}$ pepsin (Boehringer Mannheim GmbH, Germany, 108057) in $0.1 \mathrm{~N} \mathrm{HCl}$ for $30 \mathrm{~min}$ at room temperature. After centrifugation the pellet was resuspended in $2 \mathrm{ml} 2 \mathrm{~N} \mathrm{HCl}$ and incubated for $30 \mathrm{~min}$ at $37^{\circ} \mathrm{C}$. After rinsing twice in Borax buffer $(0.1 \mathrm{M}$ sodium tetraborate in distilled water, $\mathrm{pH} 8.5)$ and once in PBS/BSA containing $0.1 \%$ sodium azide $\left(\mathrm{NaN}_{3}\right)$, the cell nuclei were resuspended in $100 \mu \mathrm{l}$ appropriately diluted primary antibody (anti-BrdU, clone $\mathrm{Ilb} 5^{17}$ ) and incubated for $60 \mathrm{~min}$ at room temperature. Subsequently, the nuclei were rinsed twice in PBS/BSANaN $\mathrm{Nan}_{3}$ and resuspended in $100 \mu \mathrm{ll}$ FITC-conjugated rabbit-anti-mouse $\mathrm{F}\left(\mathrm{ab}^{4}\right)_{2}$ (code F313, DAKO A/S), diluted 1:20 in PBS/BSA. Incubation took place under protection from light during 60 min. After rinsing twice in $\mathrm{PBS} / \mathrm{BSA} / \mathrm{NaN}_{3}$, the pellet was resuspended in $0.5 \mathrm{ml}$ of a propidium iodide solution $(10 \mu \mathrm{g} / \mathrm{ml}$; Calbiochem, La Jolla, CA) containing $0.1 \mathrm{mg} / \mathrm{ml}$ RNase (Serva, Heidelberg, Germany). After $15 \mathrm{~min}$ incubation under protection of light, samples were used for flow cytometry.

For DNA/PCNA and DNA/Ki67-antigen double staining, the method initially described by Roos and Landberg ${ }^{16}$ was used. Fresh, unfixed cells were incubated in $0.5 \mathrm{mll}$ lysis buffer (PBS containing $10 \mathrm{mg} / \mathrm{ml} \mathrm{BSA}, 0.2 \mu \mathrm{g} / \mathrm{ml}$ EDTA, and $0.5 \%$ Triton $\mathrm{X}-100$ ) for $15 \mathrm{~min}$ on ice. Then, $3 \mathrm{ml}$ of methanol $-20^{\circ} \mathrm{C}$ was added and the samples were kept for $10 \mathrm{~min}$ at room temperature. After centrifugation the isolated nuclei were rinsed once in PBS and once in PBS/BSA. Nuclei were incubated with adequately diluted anti-PCNA (PC10) or anti-Ki67 antigen (MIB-1) monoclonal antibodies. The PC10 and MIB-1 antibodies were gifts from Dr. D. Lane (Dundee, UK) and Dr. J. Gerdes (Borstel, Germany), respectively. After 60 min incubation at room temperature the samples were rinsed twice in PBS/BSA. Primary antibody reaction was visualized by incubation with FITC-conjugated rabbit-anti-mouse antibody, adequately diluted in PBS/BSA, for 60 minutes at RT in the dark. After rinsing twice in PBS/BSA, the pellet was resuspended in $0.5 \mathrm{ml}$ of propidium iodide solution $(10 \mu \mathrm{g} / \mathrm{ml})$ containing 
$0.1 \mathrm{mg} / \mathrm{ml} \mathrm{RNase.} \mathrm{After} 15 \mathrm{~min}$ incubation in the dark, samples were analyzed by flow cytometry.

\section{Flow cytometry}

Part of the samples were analyzed using the FACS IV flow cytometer (Becton Dickinson, Sunnyvale, CA) equipped with a $4 \mathrm{~W}$ argon ion laser (Spectra Physics), a 520 LP filter to block scattered light, and a $540 \mathrm{BP}$ and 620 LP filter for FITC and PI fluorescence, respectively. The pulse labeled cells were used to determine the BrdU labeling index and the percentage of BrdU unlabeled S-phase cells. From the pulsechased cells, the S-phase transit time and the potential doubling time were calculated. The bivariate DNA/PCNA and DNA/Ki67-antigen analyses were performed using the FACSort (Becton Dickinson) equipped with filter sets according to the manufacturer's specification. A number of 10,000 cells per sample was recorded. The relative movement (RM) and S-phase transit time were calculated according to the method of Begg et al. From these data, the potential doubling time was calculated according to White et al. ${ }^{24}$ For detalled cell kinetic analysis, five cell cycle compantments were identified as described by Higashikubo et al "Briefly, the following populations were quantified: 1) BrdU positive undivided cells, 2) BrdU positive divided cells, 3) BrdU negative $G_{2}$ cells, 4) BrdU negative $G_{1}$ cells, and 5) $B$ rdU negative $G_{1}$ and $S$ cells. From populations 1 and 5 the mean DNA content was calculated and normalized to $\mathrm{G}_{1}$ - and $\mathrm{G}_{2} / \mathrm{M}$-phase positions.

\section{Results}

In order to study cell cycle events during nutrient depletion, NCL-H82 cells were cultured for 9 days without changing the culture medium. Various parameters, such as vitality, labeling index (LI), unlabeled S-phase fraction (USPF), S-phase transit time $\left(T_{s}\right)$, potential doubling time $\left(T_{\text {pot }}\right)$, and cell number were measured. Figures $1-3$ show the results of pooled data from separate experiments. After a period of exponential growth at the start of the experiment, no further increase in cell number was observed after day 4 (Fig. 1). At that tune the vitality and the Lil stated to decrease, while the USPF increased (Fig 2). An increase in $T_{s}$ and $T_{\text {pol }}$ became evident, starting from day 6 (Fig 3 ).

Expression of the proliferation-associated antigens PCNA and Ki67-Ag at different stages of nutrient depletion, as determined on cytospin preparations, is given in Figure 4. In general, PCNA immunoreactivity and BrdU incorporation seemed to run in parallel. During days 8 and 9 of nutrient depletion, most of the cells were non-viable and the number of PCNA positive cells declined. Ki67-Ag is expressed in the majority 


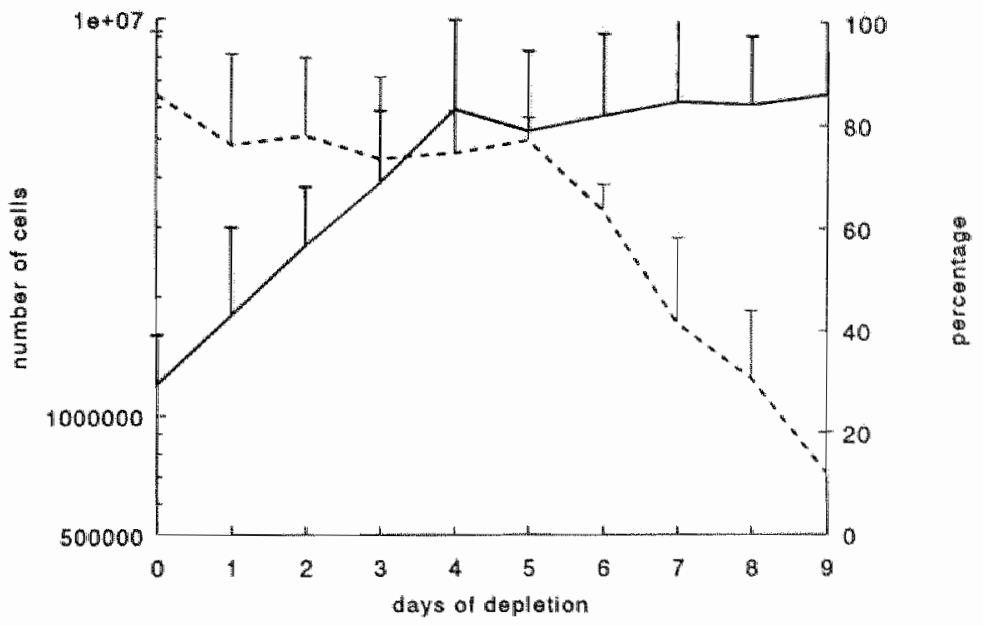

Figure 1. Cell number (left $y$-axis) and vitality (right $y$-axis) during 9 days of nutrient depletion. Data were obtained from 8 pooled experiments. Solid line: cell number. Dotted line: percentage of vital cells.

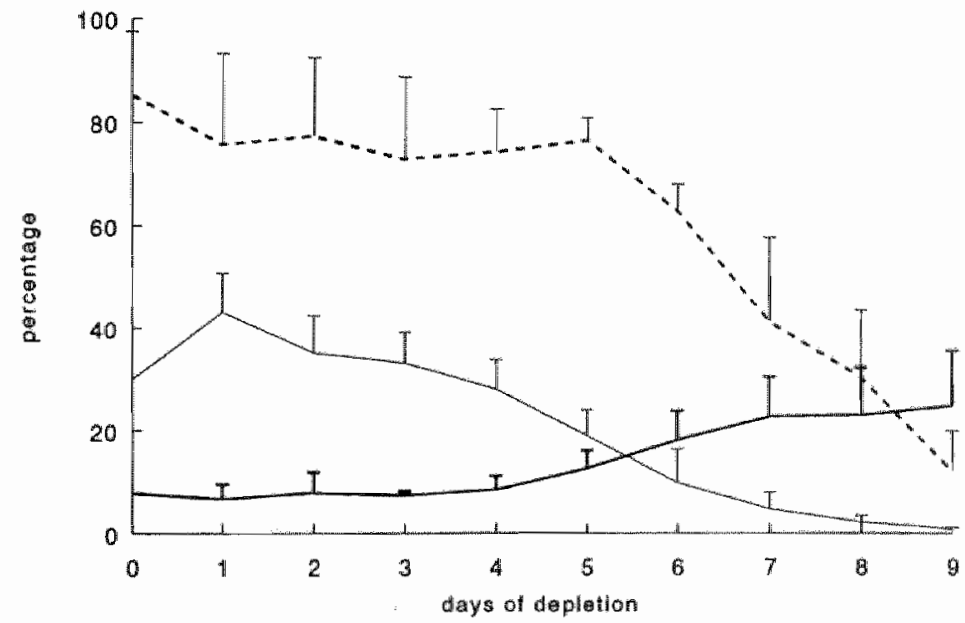

Figure 2. Brdu labeling index (LI), percentage of unlabeled S-phase cells (USPC) and vitality during 9 days of nutrient depletion. Data were obtained from 5 (LD), 4 (USPC) and 8 (vitality) pooled experiments. Thin solidil lime: percentage of Brdu labeled cells. Thick solid line: percentage of unlabeled S-phase cells. Dotted line: percentage of vital cells. 


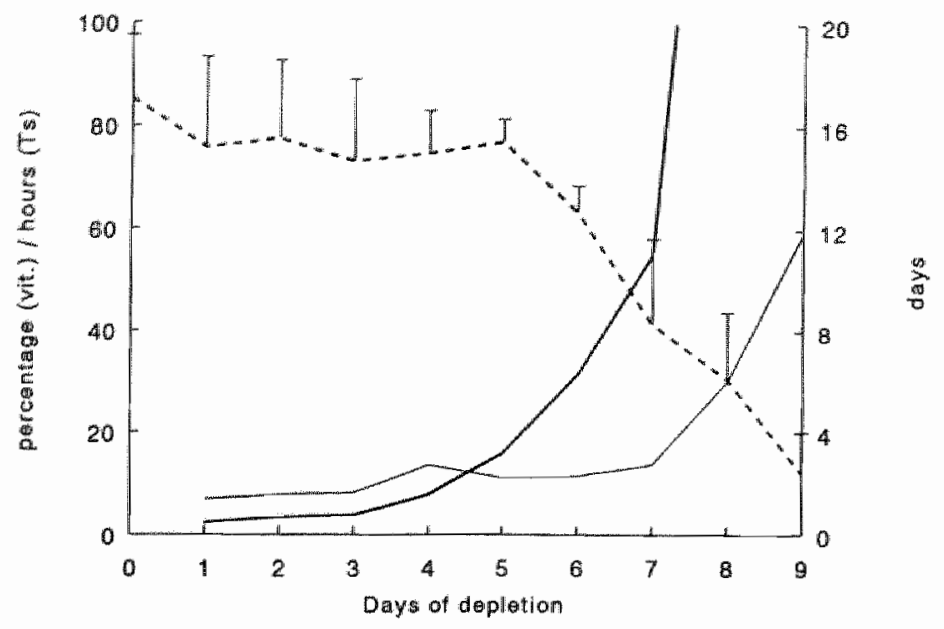

Figure 3. S-phase transit time $\left(T_{3}\right.$; left $y$-axis), potential tumor doubling time $\left(T_{\text {prexi }}\right.$ right y-axis) and witality (left $y$-axis) during 9 days of nutrient depletion. Data were obtained from $2\left(T_{\mathrm{s}}\right.$ and $\left.T_{\text {pot }}\right)$ and 8 (vitality) pooled experiments. Thin solid line: $T_{s}(h)$. Thick solid line: $T_{\text {pat }}$ (days). Dotted line: percentage of vital cells.

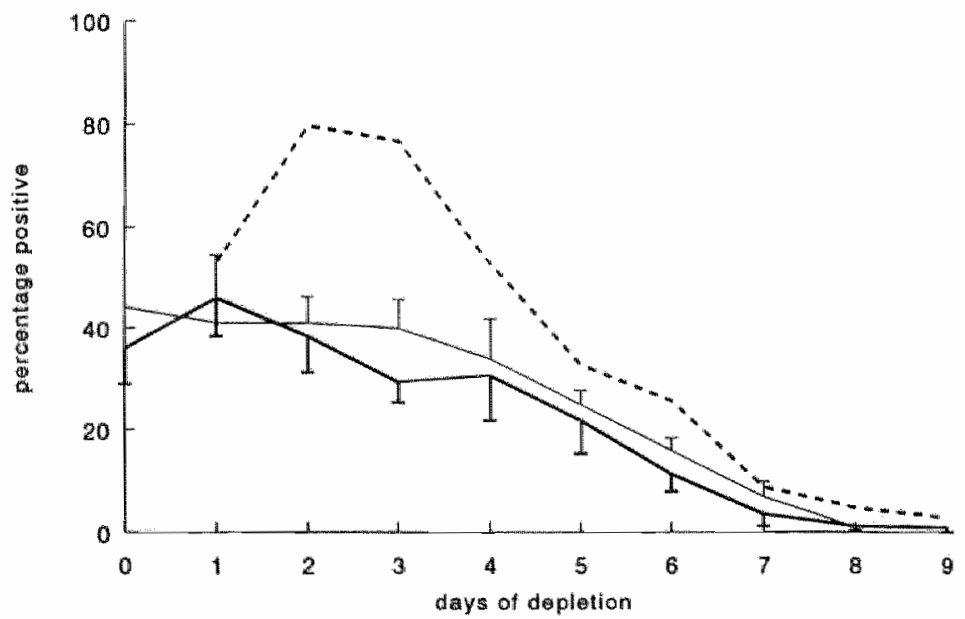

Figure 4. PCNA and Ki67-antigen expression and BrdU incorporation during 9 days of nutrient depletion. Data were obtained from 4 (BrdU), 3 (PCNA). and 2 (Ki67-antigen) pooled experiments. Thin solid lime: percentage of PCNA positive cells. Thick solid line: percentage of cells with BrdU incorporation. Dotted line: percentage of Ki67-antigen positive celts. 
of cells during the first 3 days, except for day 1. A rapid decline in Ki67-Ag expression was already observed starting from day 3 of depletion. The expression pattern changed from a clear nucleolar staining in the first days to a faint, diffuse nuclear staining in the latter period.

Since the most dramatic changes occurred in the period between day 5 and day 7 , when the majority of the cells is still viable, we studied the behavior of BrdU labeled cells after 6 days of starvation in more detail. Cell cultures were pulsed with BrdU and

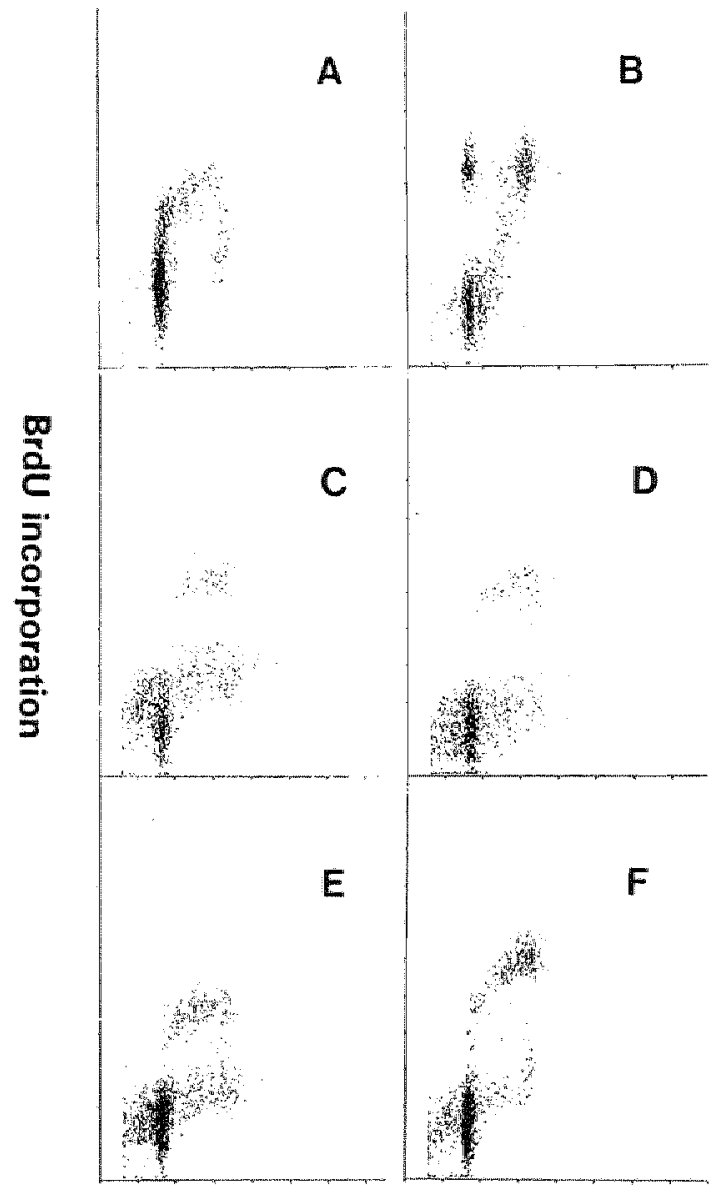

DNA content
Figure 5. Flow cytometric dot plots of pulse-chased cells at $t=0 \mathrm{~h}$ (left) and $\mathrm{t}=$ $10 \mathrm{~h}$ (right). A,B: exponentially growing cells. C,D: 6 days nutrient depleted cells. $E, F: G$ days nutrient depleted cells "repleted with fresh cullture medium. X-axis: DNA content; $y$-axis: BrdU incorporation. 
chased in either depleted or fresh culture medium. Every hour a sample was taken for bivariate BrdU/DNA analysis and every $3 \mathrm{~h}$ for bivariate PCNA/ or Ki67/DNA flow cytometric analysis. Alterations in cell progression induced by medium depletion were studied by examining the five proliferation compartments as described in Materials and Methods. As is shown in the bivariate BrdU/DNA analysis of pulse-chased cultures at day 6 (Fig. 5), unlabeled S-phase cells were observed in the depleted cultures. Furthermore, a delayed cell cycle progression was observed for the repleted cultures after a $10 \mathrm{~h}$ period of chase, while an almost complete cell cycle arrest was evident in the cell culture which was chased in depleted medium.

The values for the RM of repleted cells (Fig, 6A) show an immediate increase without any delay, however, at a slower rate compared to control cells. Starved cells which were chased in depleted medium did not show any change in RM values (data not shown). This indicates that the S-phase transit time in depleted cultures is infinite, while the $S$-phase transit time in repleted cultures is prolonged compared to control values. In contrast, the cell transit rate for both the entry and exit in $G_{1}$-phase was not altered in repleted cultures compared to controls, but a cell transit delay of approximately $10 \mathrm{~h}$ was observed (Fig. 6D). Again, in the depleted culture no cell cycle progression was observed.

As to the fate of the originally BrdU negative S-phase cells, data show that the mean DNA content of BrdU negative $G_{1}$ - and $S$-phase cells in the repleted culture remained constant during the first $10 \mathrm{~h}$. Furthermore, no transient increase in the number of BrdU negative $\mathrm{G}_{2} / \mathrm{M}$-phase cells was observed (data not shown). However, the calculated and corrected labeling indices did not show a (relative) decline in values (Fig. 6B) as would be expected due to division of cells that were originally in $G_{1}$ phase of the cell cycle at the time of BrdU pulse labeling. In contrast, the corrected LI of the repleted culture showed a tendency to increase, which is indicative for selective loss of BrdU-unlabeled cells.

In addition, a delay in $G_{1}$-phase exit was observed from the bivariate PCNADDNA analysis. Starting around $t=9$, values of PCNA LIs of the repleted population began to increase. The cells that became PCNA positive were mainly recruited from the $G_{1}$ compartment (Figs. 7E-H). This is in concordance with the observation of BrdU negative cells exiting the $\mathrm{G}_{1}$-compartment after approximately $10 \mathrm{~h}$ (Fig. 6D).

In the bivariate DNAKi67-antigen analysis, a gradual recovery of the Ki67-antigen phase-specific expression pattern is observed after repletion (Figs. 7A-D). After $12 \mathrm{~h}$, Ki67-antigen positive $G_{1}$-phase cells are detected. At the same time, the fraction of Brdu labeled undivided cells starts to decrease (Fig. 6C), indicating that cells have passed through mitosis. 

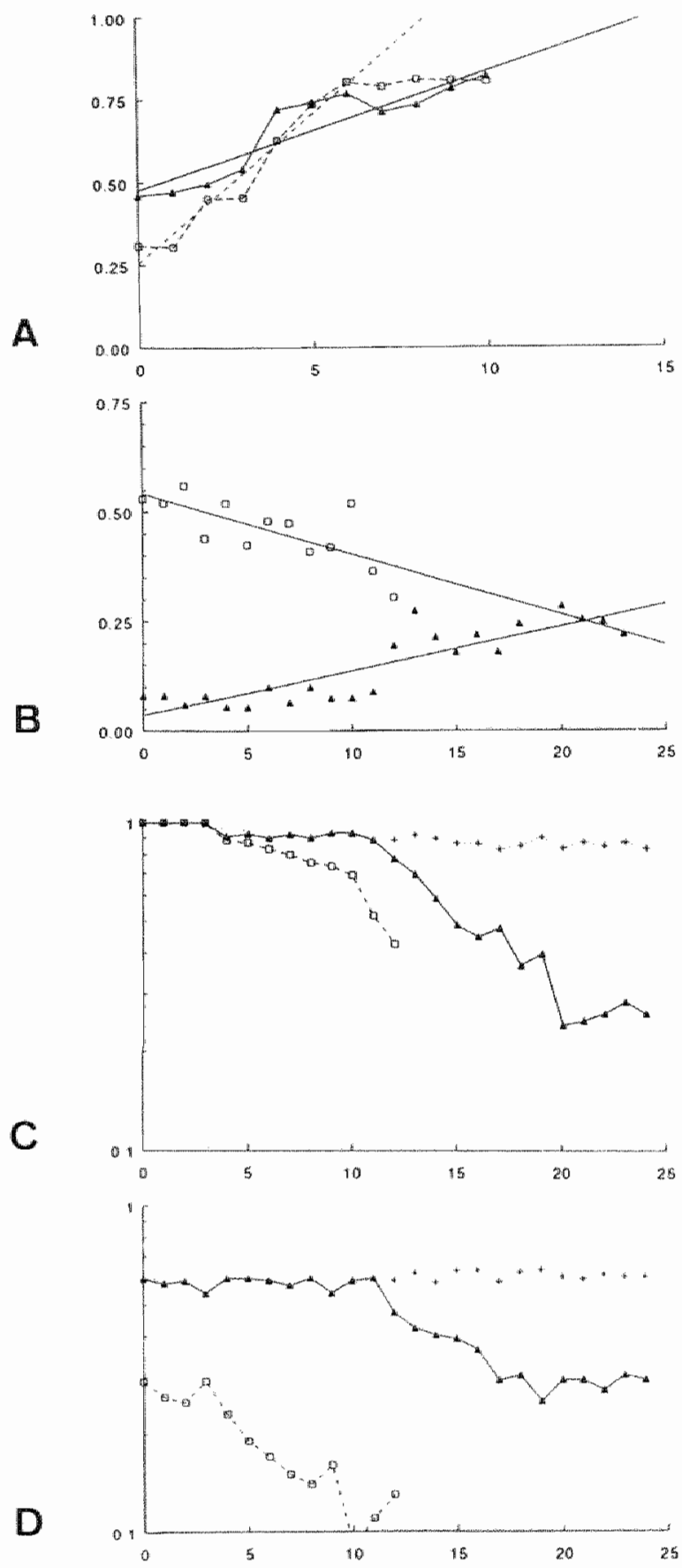

Figure 6. X-axis: time (h) after repletion.

A: Relative movement (RM) of exponentially growing (D) and repletted (M) cells. Dotted and solid lines represent lines of best fit for the RM curves of exponentially growing and repleted cells. respectively.

B: BrdU labeling indices of expomentially growing (D) and reple. ted (A) cells. Solid lines represent lines of best fit.

C: Fractions of BrdU positive, undivided cells, (D) Exponentially growing cells; $(\mathbf{A})$ repleted cells; (十) depleted cells.

D: Fractions of BroU negative cetls in $G_{4}$. (G) Exponentially growing cells; ( $\mathbf{A}$ ) repleted cells; (4) depleted cells. 
A

E

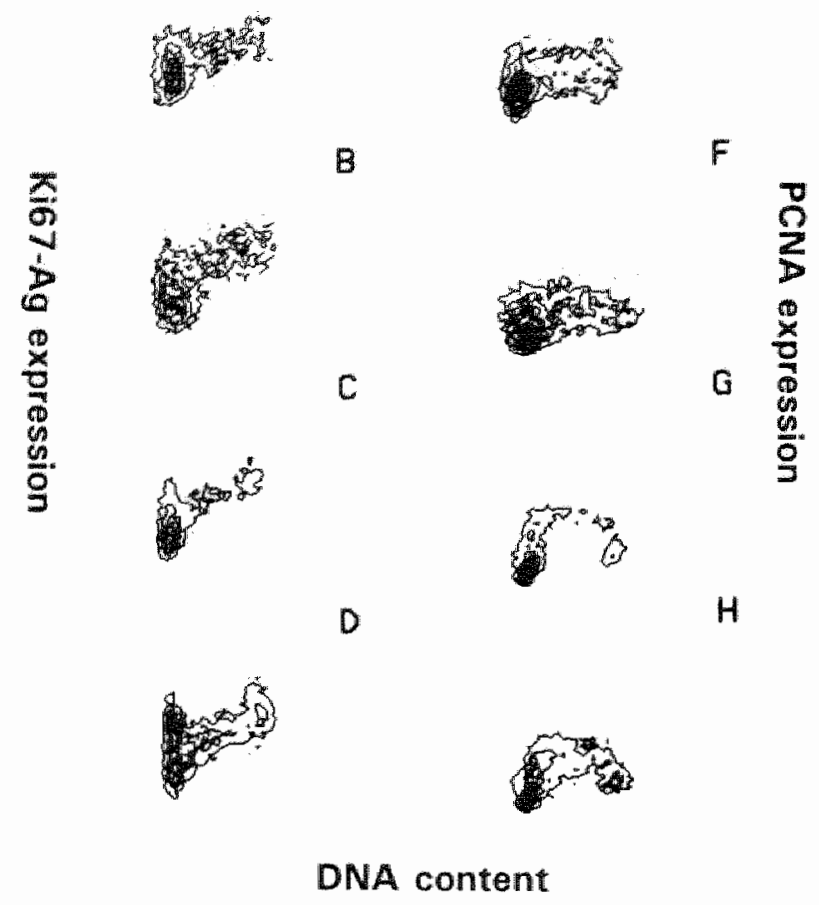

Figure 7. Flow cytometric contour plots of $K[67$-antigen (A-D) and PCNA $(E-H)$ expression in 6 days depleted cells $0 \mathrm{~h}(A, E), 9 \mathrm{~h}$ $(B, F), 12 h(C, G)$ and $18 \mathrm{hl}(\mathrm{D}, \mathrm{H})$ after repletion with fresh culture medium. X-axis: DNA content; y-axis: Ki67-Ag or PCNA antigen expression.

\section{Discussion}

In this paper we have demonstrated in a small cell lung cancer cell line that S-phase arrest can occur during conditions of nutrient depletion. As predicted in theory by White ${ }^{23}$, cell arrest is not only indicated by the presence of non-BrdU labeled cells with an S-phase DNA content but also by the inability of BrdU labeled cells to proceed through S-phase. In experiments in which cells were pulse chased with BrdU after 6 days of nutrient deprivation, we observed such a static population of BrdU 
labeled cells. In addition, our experiments showed that the occurrence of unlabeled Sphase cells, as well as the increase in S-phase transit time and potential doubling time, was most pronounced at the time when the overall growth and the vitality of the cell culture decreased. According to the theory of White ${ }^{23}$, a prolonged S-phase transit time goes together with cell arrest. S-phase cells unable to incorporate BrdU were also reported in human xenotransplanted solid tumors by Baisch and $\mathrm{Otto}^{2}$ and in human and mouse tumors by ten Velde et al. ${ }^{21}$, Forster et al. ${ }^{9}$, and Wilson et al. ${ }^{25}$ The phenomenon was in most cases explained by cell arrest due to a changing microenvironment. In the latter two of these papers, also prolonged $S$-phase transit times are reported. The most likely explanation for the occurrence of unlabeled S-phase cells in the underlying study indeed seems to be cell cycle arrest rather than inadequate diffusion of BrdU throughout the tissue. We expect the same phenomenon to be at least partly responsible for the unlabeled S-phase cells found in in vivo labeled lung tumor tissue ${ }^{19.21}$, considering the prolonged S-phase transit times and potential tumor doubling times calculated from these specimens. If inadequate diffusion of BrdU was the main problem, then cells that do incorporate the label would participate in the cell cycle at a normal rate, and thus the S-phase transit time would not be affected. Furthermore, the number of cells expressing PCNA is almost identical to the number of cells actively incorporating BrdU (see Fig. 4). In case of diffusion limitations, one would expect a greater discrepancy in the frequencies of cells positive for PCNA and BrdU incorporation. Finally, in a small series of patients we analyzed the topographical distribution of in vivo BrdU labeled cells in relation to the blood vessels in tissue sections. No direct evidence for poor diffusion of $\mathrm{BrdU}$ was found, since labeled cells were found both in the proximity as well as at great distance of neighboring blood vessels (data not shown). However, diffusion problems in the in vivo situation cannot entirely be ruled out.

We furthermore addressed the question of whether the observed cell cycle arrest is reversible. The possibility that tumor cells, being arrested in the cell cycle under suboptimal conditions, can regain their cycling capacity when the growth restriction is released, is of clinical and therapeutic importance. Repletion experiments, in which 6 days nutrient depleted cells were provided with fresh culture medium and were monitored for $24 \mathrm{~h}$, show a population of BrdU labeled cells as well as non-labeled cells. The cell cycle block observed in the nutrient depleted culture can obviously be removed when cells are repleted with fresh culture medium (cf. Fig. $5 C_{x} D$ and Fig. $5 \mathrm{E}, \mathrm{F})$. This is also observed from the immunocytochemical staining patterns for PCNA and Ki67-antigen. In depleted cells, the expression of these antigens gradually disappears (see Fig. 4). Particularly the Ki67-antigen, which is reported to be a reliable marker for the evaluation of growth fractions in tumors $\mathrm{s}^{10,18}$, seems to be sensitive to the nutritional status of cells, as it declines rapidly after 3 days of nutrient depletion. Baisch and Gerdes', van Dierendonck et al ${ }^{\circ}$, and Verheijen et al ${ }^{20}$ reported a loss of correlation between Ki67-antigen immunoreactivity and proliferation in nutritionally deprived cells. After repletion, however, recovery of specific expression 
patterns for PCNA and Ki67-antigen is seen in a flow cytometric bivariate analysis of these antigens vs. DNA content.

As is indicated by the relative movement of the BrdU labeled undivided fraction (Fig. $6 \mathrm{~A}$ ), the labeled cells proceed through the $S$-phase of the cell cycle after nutrient repletion, but at a slower rate than in control cultures. After a delay of approximately $10 \mathrm{~h}$ these cells enter the $\mathrm{G}_{1}$-comparment at normal rates.

Directly after repletion also cells exiting the $G_{1}$-phase showed a delay. A likely explanation for this phenomenon is an arrest at the $\mathrm{G}_{1}$ restriction point. All cell cycle regulatory checkpoints, known to date, are located either in $G_{1}$ or in $G_{2}$-phase of the cell cycle ${ }^{\mid 2,13,15}$. These cell cycle control mechanisms are thought to prevent cells to enter the cell cycle under suboptimal conditions or to ensure proper mitosis. In this way the occurrence of genetically defective cells should be prevented. However, Baserga ${ }^{3}$ and Pardee ${ }^{14}$ found evidence for a defective $G_{1}$ controll in cancer cells. Apparently some tumor cells are able to enter the cell cycle under conditions insufficient for normal proliferation. In this study, proper functioning of the $G_{1}$ control mechanism in $\mathrm{H} 82$ cells cannot be assured, since cells managed to get by the restriction point and then encountered problems in S-phase, before the culture medium was changed. A delay in $G_{1}$-phase transit is also observed from the bivariate DNA/PCNA analysis. Cells appear to be blocked in $G_{1}$ during the first hours of repletion. Higashikubo et al. " found that exposure of cells to hyperthermia induced two distinct modes of alteration in cell progression, i.e., a delay in cell transit and a decrease in the rate of cell transit. The experiments described in this paper seem to generate a similar effect: exposure of cells to nutrient depletion leads to a delay in cell transit in $G_{1}$ and to a decrease in the rate of cell transit in the labeled S-phase cells.

During nutrient depletion, an increasing number of unlabeled S-phase cells was registered. When cells were repleted with fresh medium, this population seemed to be gradually reduced. However, no movement of this cohort was observed. Therefore, we conclude that these BrdU-negative S-phase cells are irreversibly arrested and are eventually lost from the culture.

Cell arrest in S-phase has not only been described in theory, but was also defined in cell cultures. Wei et al. ${ }^{2 / 2}$ recently demonstrated that yeast cells could enter a reversible quiescent state at any point of the cell cycle and suggested that this might be an explanation for the unlabeled S-phase fractions observed after in vivo BrdU labeling of tumor specimens. Baisch and Otto found an intratumoral heterogeneity of S-phase transition times in xenotransplanted human tumors, which was attributed to the presence of cells with S-phase DNA content and without BrdU labeling, referred to as S-phase quiescent cells. These observations suggest that cell arrest is due to a regulatory process in which cells temporarily exit from the cell cycle into a quiescent state. From our experiments, it is not likely that unlabeled S-phase cells are quiescent cells.

In the presented data we showed that in a cell culture which has been subjected to prolonged starvation, S-phase cells are able to incorporate BrdU, but subsequently are 
unable to proceed through the cell cycle when chased in depleted culture medium. A possible explanation for this contradictory phenomenon could be a depletion of the endogenous thymidine pool, possibly caused by inhibition of thymidylate synthase, which is a known mechanism for growth inhibition. In our experiment, the lack of thymidine is temporarily compensated by the addition of the thymidine analogue BrdU. Subsequent progression through S-phase might be blocked by the lack of other nucleosides. As a result, the DNA synthesis stops and cells arrest in the S-phase of the cell cycle. Prolonged inhibition of the enzyme thymidylate synthase can eventually lead to cell death by a process called "thymineless death"6.

In this paper we have shown that the presence of unlabeled S-phase cells and; as a consequence, a prolonged S-phase transit time, can be caused by lack of nutrients. This process is partly reversible, depending on the duration of cell cycle arrest. When cells are arrested for longer periods of time in S-phase, the process seems to become irreversible. This is also evident from the simultaneous increase of the number of unlabeled S-phase cells and the number of non-viable cells.

\section{Acknowledgement}

This research was financially supported by the Dutch Cancer Socicty, 


\section{References}

1 Baisch $\mathbb{H}$, Gerdes J: Simultancous staining of exponentially growing wersus plateau phase cells with the proliferation-associated antibody Ki67 and propidium lodide: Analysis of flow cytometry. Cell Tissue Kiner 20:387-391 (1987).

2 Baisch $\mathrm{H}$, Otto U: Intratumoral heterogeneity of S phase transition in solid turnours determined by bromodeoxyuridine labelling and flow cytometry. Cell Prolif 26:439-448 (1993). Baserga R: The Biology of Cell Reproduction. Harvard Uniwersity Press, Cambridge (1985) Begg AC, MeNally NJ, Schrieve DC, Karcher H: A method to measure the duration of DNA synthesis and the potential dowbling time from a single sample. Cytomerry 6:620-626(1985) Bravo R, Macdonald-Bravo H: Existence of two populations of cycliv/proliferating cell nuclear antigen during the cell cycle: Association with DNA replication sites. J Cell Biol 105:1549-1554 (1987).

Curtin $\mathrm{NJ}_{3}$ Harris $\mathrm{AL}$, Aherne GW: Mcchanism of cell death following thymidylate synthase inhibition: 2'-Deoxyuridine-5'-triphosphate accumulation, DNA damage, and growth inlibition following exposure to CB3717 and dipyridamole. Cancer Res 51:2346-2352 (1991).

Darzynkiewicz Z: Cytochemical probes of cycling and quiescent cells applicable to flow cylometry. In: Techniques in Cell Cycle Analysis, Gray JE, Darzynkiewicz Z (eds). Human Press, Inc. Clifton, ${ }_{1}$ NJ, pp 255-290 (1986).

8 Van Dierendonck JH, Keijzer R, van de Velde CJH, Comclisse CJ: Nuclear distribution of the Ki67 antigen during the cell cycle: Comparison with growth fraction in human breast cancer cells. Cancer Res 49:2999-3006 (1989).

9 Forster G, Cooke TG, Cooke LD, Stanton PD, Bowie G, Stell PM: Tumor growth rates in squamous carcinoma of the head and neck measured by in vivo bromodeoxyuridine incorporation and flow cytometry. Br J Cancer 65:698-702 (1992) Gatter KC, Dunill MS, Gerdes J, Stein H, Mason DY: New approach to assessing lung tumours in man. J Clin Parhol 39:590-593 (1986).

11 Higashikubo R, White RA, Roti Roti JL: Flow cylometric BrdUnd-pulse-chase study of heatinduced cell-cycle progression delays. Cell Prolif 26:337-348 (1993). Molokura T, Arnold A: Cyclins and oncogenesis. Biochim Biophys Acra 1155:63-78 (1993). Nurse P: Universal control mechanism requlatine onset of M-phase Noture $344 \cdot 502.508$ $(1990)$.

14 Pardee AB: Molecules involved in proliferation of normal and cancer cells. Cancer Res 47:1488$1491(1987)$.

15 Pardec AB: $\mathrm{O}_{1}$ events and regulation of cell proliferation. Science 246: 603-608 (1989).

16 Roos $\mathrm{G}$, Landberg $\mathrm{G}$. Flow cytomeiric analysis of proliferation associated nuclear antigens using washless staining of unlixwed cells. Cytometry 13:230-240 (1902).

17 Schutte B, Reynders MMJ, Van Assche CLMVJ, Hupperets PSJG, Bosman FT, Blijham GH: An improved method for the immunocytochemical detection of bromodeoxyruridine labeled nuclei using flow cylonetry. Cytometry 8:372-376 (1987).

18 Simony J, Pujol J-L, Radal M, Ursule E, Michel F-B, Pujol H: In situ evaluation of growth fraction determined by monoclonal antibody $\mathrm{Ki}-67$ and ploidy in surgically resected non-small cell lung cancers. Cancer Res 50:4382-4387 (1990)

Timnenans MMFJ, Schutte B, Lenders M-HJH, Ten Velde GPM, Ramackers FCS, Blijham GH: Cytokinctic analysis of lung cancer by in vivo bromodeoxyuridine labelling. Br $J$ Cancer $67: 1217-1222(1993)$ 
20 Verheijen R, Kujipers HJH, Van Driel R, Beck JLM, Van Dierendonck JH, Brakenhof GI, Ramaekers FCS: Ki67 detects a nuclear matrix associated proliferation-related antigen. $J$ Cell Sor $92: 531-540(1989)$

21 Ten Velde GPM, Schutte B, Reynders MMJ, Bosman FT, Blijham GH: Cytokinetic analysis of lung cancer by bromodeonyuridine labeling of cytology specimens. Cyromery 10:807-810 (1989)

22 Wei W, Nurse P, Broek D. Yeast cells can enter a quiescent state through G1, S, G2, or M phase of the cell cycle Cancer Res 53:1867-1870 (1993).

23 White RA: A theory for analysis of cell populations with non-cycling S phase cells. $J$ Theom Biol $150: 201-214(1991)$.

24 White RA, Terry NHA, Meistrich ML, Calkins DP: Improved method for computing potential doubling time from flow cytometric data. Cytometry 11:314-317 (1990).

25 Wilson GD, McNally NJ, Dunphy E, Kärcher H, Pfragner R: The labelling index of human and mowse tumours assessed by bromodeoxyuridine staining in vitro and in vivo and llow cytometry. Cyromery 6:64 1-647 (1985). 


\section{Alterations in cytoskeletal and nuclear matrix associated proteins during apoptosis}

Monique MF」 Tinnemans, Marie-Hélêne JH Lenders, Guul PM ten Velde, Frans CS Ramaekers and Bert Schutte

Department of Molecular Cell Biology \& Genetics, Universify of Limburg; Departments of Internal Medicine and Pulmonalogy, University Hospital Maastricht.

Eur u Cell Biol 68: 35-46 (1995) 


\section{Summary}

Evidence exists that apoptosis or programmed cell death plays an important role in tumor growth. Morphologically, apoptosis is characterized by membrane blebbing and nuclear fragmentation in individual cells. In this study, we investigated changes in the nuclear organization in spontaneously occurring apoptotic cells in several lung cancer cell lines using several antibodies to nuclear matrix constituents. It appeared that nuclear matrix components remained detectable in cells undergoing spontaneous apoptosis. The same results were found when apoptosis was induced by cycloheximide in the non-small cell lung cancer cell line MR65. Using this induction method, the percentage of apoptotic cells in MR65 cells increased, allowing a more detailed and extensive examination of nuclear matrix alterations together with cytoskeletall changes. To study the expression of cytokeratins, type $A$ - and B lamins, a nuclear matrix associated $13 \mathrm{kDa} \mathrm{U}_{1} \mathrm{RNP}$ particle and the Ki67-antigen, immunocytochemistry in combination with confocal scanning laser microscopy was used. Apoptotic cells were identified based on nuclear morphology and the in situ nick translation assay. Whereas immunoreactivity against lamins and $\mathrm{Ki} 67-\mathrm{Ag}$ was rapidly lost during apoptosis, expression of the $13 \mathrm{kDa}$ protein and, in early apoptotic stages also cytokeratin expression, was observed to remain present. Dead cells lacked reactivity with all the antibodies tested. The persistence of nuclear matrix components is therefore a useful marker for the detection of apoptosis.

\section{Introduction}

The balance between proliferation and cell death is a determining factor in the growth kinetics of normal and neoplastic tissue. In neoplastic tissue two major forms of cell death are recognized, i.e., necrosis and apoptosis ${ }^{36.3}$. Discrimination between these wo phenomena is important in understanding mechanisms of tumor growth.

It is generally believed that necrosis, frequently observed in the central parts of a tumor, is caused by changes in microenvironmental conditions, such as insufficient vascularization. Due to lack of oxygen and nutrient supply, metabolic functions cease, resulting in a loss of osmotic regulation and consequent cellular swelling of affected cells $s^{3}$. On the other hand, apoptosis, originally described in $1972^{24}$ and also referred to as programmed cell death, is observed in individual cells and involves transcription of specific genes, as well as the activation of an endogenous endonuclease with high affinity for internucleosomal linker DNA regions 2 . Apoptosis is characterized by a changing morphology of both cell nucleus (disintegration) and cyloplasm (membrane blebbing $)^{56}$. 
Apoptosis is essential in many physiological processes, such as controlled deletion of cells in tissue and organ development during embryogenesis ${ }^{17,32}$ and maturation of the immune system ${ }^{9,33}$. To date, increasing evidence suggests that apoptosis plays an important role in the regulation of tumor growth ${ }^{3}$. Various genes have been described that mediate the resistance or susceptibility of cells to apoptosis. Many of these genes, such as p53, c-myc, bcl-2 and Ha-ras, are often abnormally expressed or regulated in neoplasms. The c-myc gene, for example, stimulates either cell proliferation or cell death, depending on the availability of critical growth factors ${ }^{\| 2}$. Cells overexpressing c-myc are more prone to cell death in the absence of growth factors and often become apoptotic. Another regulator is the bcl-2 gene product, which appears to 'rescue' various cell types from apoptosis ${ }^{6,29}$. Induction of apoptosis by various stimuli is blocked by the bcl-2 protein, which is thought to function as an antagonist of a central mechanism operative in cell death ${ }^{20}$. McDonnell et al. ${ }^{34}$ found that overexpression of bcl-2 in transgenic mice leads to accumulation of cells due to evasion of normal cell death mechanisms. The importance of apoptosis in normal development is also evident from the high degree of homology between the bcl-2 gene and ced-9, one of the cell death genes identified in the nematode Caenorhabditis elegans ${ }^{19}$. A similar protective action against apoptosis is exerted by high expression of the mutated Ha-ras gene $e^{3,57}$. In contrast, wild-type p 53 seems to sensitize cells to apoptosis, and in this way acts as a growth regulator. P53 has been shown to be mutated in $50 \%$ of human cancers ${ }^{21}$, which may attribute to the accumulation of genetically aberrant cells.

So far, little aftention has been paid to the explanation of morphologically visible processes in an apoptotic cell, such as membrane blebbing. Buja et al ${ }^{7}$ reported that loss of normal membrane organization can be caused by damage to the cytoskeleton. Cytoskeletal changes also appear to be involved in the loss of cell-cell contact, which is also observed during apoptosis. Pasdar and $\mathrm{Li}^{40}$ described the requirement of intact cytokeratin filaments for stability, efficient assembly and spatial organization of the junctional components at the membrane. Significant changes in the structure of the cytoskeleton in combination with morphological features of apoptosis were observed by Squier et al..$^{46}$ and Walski et al. ${ }^{33}$ The occurrence of nuclear fragmentation furthermore suggests changes in the nuclear matrix of an apoptotic cell. Miller et al. ${ }^{35}$ found that the nuclear matrix changed during cell death; however, the type of change was dependent on the agents that triggered cell death.

In the present study, spontaneously occurring apoptotic cellls in warious lung cancer cell lines are examined with respect to changes in the nuclear matrix. In contrast to dead cells, apoptotic cells seem to preserve certain nuclear matrix components. In a cycloheximide induction model, the non-small cell lung cancer cell line MR65 showed dramatic changes in both cytokeratin and nuclear matrix-associated protein expression patterns during apoptosis. By combining staining of the nuclear matrix with the in situ nick translation assay, a clear distinction can be made between apoptotic and dead cells. 


\section{Materials and Methods}

\section{Cell culture and induction of apoptosis}

The human squamous lung carcinoma cell line MR65, kindly supplied by Dr. Gropp (Philips Universitats Klinik, Marburg/Germany), was grown as a monolayer cultured in HEPES buffered Eagle's modified minimal essential medium (EMEM; Gibco, Paisley, Scotland), supplemented with $10 \%$ newborn calf serum (Gibco), 1\% of Lglutamine (Serva, Heidelberg, Germany) and $0.1 \%$ of gentamycin (AUV, Cuyck, The Netherlands). The non-small cell lung cancer cell line NCI-H810, that was kindly supplied by Dr. Linnoila (NCl, DCP, Rockville, MD, USA) was cultured in HEPES buffered RPMI 1640 medium (Flow, ICN Biomedicals, Costa Mesa, CA, USA) supplemented with $15 \%$ fetal calf serum (Gibco), glutamine and gentamycin. All the other cell lines used in this study were cultured in RPMI 1640 medium supplemented with $10 \%$ newborn calf serum. Dr. Linnoila also supplied the non-small cell lung cancer cell lines NCI-H460 and NCI-H1155. The variant-type small cell lung cancer cell line NCI-H82 and the non-small cell lung cancer cell line NCI-H23 were kindly supplied by Dr. Carney (Mater Misericondiae Hospital, Dept. of Medical Oncology, Dublin, Ireland). Two other variant-type small cell lung cancer cell lines SCLC21H and GLC-1 were kindly supplied by Dr. Bepler (Duke University Medical Center, Dept. of Medicine, Durham, NC, USA) and Dr. de Leij (University Hospital Gromingen, Dept. of Clinical Immunology, Groningen, The Netherlands), respectively. The classic-type small cell lung cancer cell line NL-SCLC2 was kindly supplied by Dr. Broers (University of Limburg, Dept. of Molecular Biology \& Genetics, Maastricht, The Netherlands). Cells growing in monolayers were harvested by trypsinization. Cells that grow in suspension were mechanically disaggregated The number of cells was counted and the vitality was detemined by trypan blue exclusion.

Apoptosis was induced in MR65 cells by treating exponentially growing cells with $500 \mu \mathrm{g} / \mathrm{ml}$ cycloheximide (Sigma, St. Louis, MO, USA; no. C-6255). A concentration range of $1101000 \mu \mathrm{g} / \mathrm{ml}$ was tested.

\section{Cell fixation}

Per sample, $1 \times 10^{4}$ cells were cytocentrifuged on glass slides (Starfrost, Knittel Glaser, Braunschweig, Germany) and air dricd for at least $2 \mathrm{~h}$. For immunocytochemistry, the slides were fixed for $5 \mathrm{sec}$ in ice-cold methanol, immediately followed by $3 \times 5$ sec in acetone at toom temperature (RT). For the in situ nick translation 
(ISNT) assay a short fixation ( 1 mim. RT) with methacarn (6 parts of methanol, 3 pants of chloroform and 1 part of glacial acetic acid) was used.

\section{Antibodies}

The following primary antibodies were used: 1) Monoclonal antibody RCK 102 to cytokeratins 5 and $8^{41}$;2) monoclonal antibody $M 20$ to cytokeratin 8 was a genenous gift from Dr. van Muyen (University of Nijmegen, The Netherlands) ${ }^{4 / 4}$ 3) monoclonal antibody $\mathrm{LP} 2 \mathrm{~K}$ to cytokeratin 19 was a generous gift from Dr. E.B. Lane (Dundee, UK. $)^{30}$; f) monoclonal antibody IIB5 to bromodeoxyuridine ${ }^{\text {;5 }}$;) monoclonal antibody RN3, specific for a $80 \mathrm{kDa}$ subunit of the Ku-autoantigen complex. Cell fractionation studies revealed that a significant amount of the $80 \mathrm{kDa} \mathrm{Ku}$-component is associated with the nuclear matrix ${ }^{49}$; 6) hybridomas producing anti-lamin $\mathrm{A} / \mathrm{C}$ (clone $41 \mathrm{CC} 4$ ) and anti-lamin $B_{2}$ (clone LN43) were generous gifts from Dr. Burke, (Boston, MA, USA), and Dr. E.B. Lane (Dundee, UK), respectively; 7) monoclonal antibody $133 \mathrm{~A} 2$ to lamin $\mathrm{A}$ was a generous gift from Dr. Raymond (Montreal, Canada) 22 , 8) monoclonal antibodies 7.13 and 2.73 , which are directed against the $13 \mathrm{kDa} \mathrm{D}$-protein ${ }^{30}$ and the $70 \mathrm{~K}$-protein ${ }^{5}$ of $U_{1}$ RNP particles, respectively. These components are associated with the nuclear matrix and were kindly provided by Dr. Hoch (La Jolla, CA, USA); 9) anti-Ki67-antigen (M722) was obtained from DAKO A/S (Glostrup, Denmark).

As secondary antibodies we used peroxidase conjugated rabbit-anti-mouse Ig (P260), fluorescein isothiocyanate (FITC)-conjugated $\mathrm{Fab}_{2}$ fragments of rabbit-anti-mouse $\operatorname{lgG}$ (F3 13), phycoerythrin (PE)-conjugated goat-anti-mouse (R480) and FITC-conjugated strepavidin (F422), all from DAKO A/S.

\section{Immunocytochemistry}

Slides were incubated with primary antibodies, appropriately diluted in phosphate buffered saline (PBS) containing $0.1 \%$ bovine serum albumin (BSA; Sigma, no. A7030), for 1 h at room temperature in the dark. After two washing steps, primary antibody binding was visualized by incubating the slide for $1 \mathrm{~h}$ with appropriately diluted FITC-conjugated rabbit-anti-mouse lg. Slides were then incubated for 15 min in PBS containing propidium iodide (PI; Calbiochem, La Jolla, CA, USA) and RNase (Sigma, no.R-4875), and embedded in glycerol/DABCO $(1,4$ diazabicyclo- $(2,2,2)$ octane; 9 parts of glycerol, I part of $0.2 \mathrm{M} \mathrm{This-HCl} \mathrm{pH} 8.0,0.02 \% \mathrm{NaN}$ and $2 \%$ DABCO (Merck, Darmstadt, Germany; no. 803456), pH 8.0) containing $0.5 \mu \mathrm{g} / \mathrm{ml} \mathrm{Pl}$. Evaluation of the samples was performed by confocal laser scanning microscopy using the BioRad MRC600, mounted onto a Zeiss Axiophot. Different patterns of antigen expression were scored on normal interphase cells, apoptotic cells and dead cells. In negative controls, anti-BrdU was used as the primary antibody. 
in situ nick translation

Nicked DNA was detected using a modification of the protocol originally described by Wijsman et al. ${ }^{54}$ Briefly, after methacarn fixation, slides were immediately rinsed in PBS, followed by an extraction for $10 \mathrm{~min}$ on ice in $0.1 \mathrm{M}$ citric acid, containing $0.5 \%$ Triton X-100. After two times rinsing in PBS, slides were rinsed in buffer A $(50 \mathrm{~mm}$

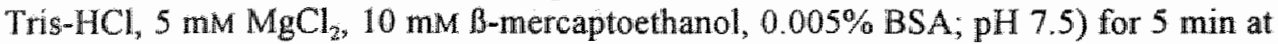
RT. Nucleotide insertion into the 'nicks' was performed by incubation for $30 \mathrm{~min}$ at RT with $0.01 \mathrm{mM}$ unlabeled dATP, dCTP and dGTP (ultrapure dNTP set, Pharmacia, Uppsala, Sweden; no. 27-2035-01), $0.01 \mathrm{~mm}$ bio-11-dUTP (Fermentas, Vilnius, Lithuania; no. AT-03) and $20 \mathrm{U} / \mathrm{ml}$ DNA polymerase I (Promega, Madison, WI, USA; no. M205A) in buffer A. After rinsing once in $4 \times$ standard saline citrate (SSC; Merck) containing $0.05 \%$ Tween 20 for 5 min, once in $4 \times$ SSC containing $4 \%$ non-fat dry milk (NFDM) for $10 \mathrm{~min}_{\text {, }}$ and once again in $4 \times \mathrm{SSC} / 0.05 \%$ Tween 20 for $5 \mathrm{~min}$, slides were incubated with FITC-conjugated streptavidin diluted $1: 50$ in $4 \times \mathrm{SSC} / 4 \%$ NFDM for 60 min at RT. This was followed by rinsing in $4 \times$ SSC/0.05\% Tween 20 for $5 \mathrm{~min}$, and embedding in glycerol/DABCO containing $0.5 \mu \mathrm{g} / \mathrm{ml}$ PI. Negative controls were treated in the same way, but no polymerase I was added.

\section{Combined immunocytochemistry and in situ nick translation in cell suspension}

One million ethanol fixed cells were rinsed once in PBS followed by an extraction with $0.1 \mathrm{M}$ citric acid $/ 0.5 \%$ Triton X-100 for $10 \mathrm{~min}$ on ice. First, in situ nick translation was performed; the same protocol for incorporation of biotinylated nucleotides was used as described above. After washing twice in PBS/BSA, appropriately diluted FITC-conjugated streptavidin together with antibody 7.13 or anti-cytokeratin RCK 102 antibody was added to the cell pellet, and the cells were resuspended. After $1 \mathrm{~h}$ of incubation at RT in the dark, the cells were rinsed twice in PBS/BSA, and antibody binding was visualized by incubation with phycoerythrin (PE)-conjugated goat-antimouse. Cells were then washed with PBS and were finally diluted in PBS/PI(0.5 $\mu \mathrm{g} / \mathrm{ml}) / \mathrm{RNAse}(100 \mu \mathrm{g} / \mathrm{ml})$. In negative controls, DNA polymerase I was left out and anti-BrdU was used as the primary antibody.

\section{Flow cytometry}

For flow cytometric analysis a FACSort (Becton Dickinson, San Jose, CA, USA) equipped with a single Argon ion laser was used. The exciting light was $488 \mathrm{~nm}$, and the emission filters were 515-545 BP (green; FITC), 572-588 BP (orange; phycoerythrin) and $600 \mathrm{LP}$ (red; PI). A minimum of 10,000 cells per sample was stored in list 
mode. FITC and PE signals were recorded as logarithmic amplified data, while the PI signal was recorded as linear amplified data. For bivariate FITC/PI analysis no compensation was used.

For tricolor analysis the following settings were used: $400 \mathrm{~V}, 405 \mathrm{~V}$ and $350 \mathrm{~V}$ on photomultiplier tubes for FL1 (FITC), FL2 (PE) and FL3 (PI), and $1.1 \%, 38.9 \%$, $42.8 \%$ and $7.0 \%$ compensation for (FL1-\%FL2), (FL2-\%FL1), (FL2-\%FL3) and (FL3-\%FL2), respectively, where FL1, FL2 and FL3 are the green, orange and red fluorescence signals, respectively.

Data analysis was performed with the standard Lysis and Cellfit software (Becton Dickinson). As a standard procedure for all analyses, data were gated on pulse processed $\mathrm{PI}$ signals to exclude doublets and larger aggregates.

\section{One-dimensional gel electrophoresis and Western blotting}

Apoptosis was induced in MR65 cells by treating exponentially growing cells with $500 \mu \mathrm{g}$ cycloheximide for $16 \mathrm{~h}$. Then, floating cells were collected by centrifugation and the cell pellet was washed with PBS and resuspended in $400 \mu$ lysis buffer (62.5 $\mathrm{mM}$ Tris- $\mathrm{HCl} \mathrm{pH} 6.8,12.5 \%$ glycerol, $2 \%$ Nonidet P-40 (NP40), $2.5 \mathrm{~mm}$ phenylmethylsulfonyl chloride, $1.25 \mathrm{mM}$ EDTA, $12.5 \mu \mathrm{g} / \mathrm{ml}$ leupeptin and $116 \mu \mathrm{g} / \mathrm{ml}$ aprotinin). As a control, non-CHX-treated exponentially growing MR65 cells were rinsed with PBS, scraped, collected and resuspended in $800 \mu \mathrm{l}$ lysis buffer. The cell lysates were kept on ice for $30 \mathrm{~min}$.

One-dimensional sodium dodecyl sulfate polyacrylamide gel electrophoresis (SDSPAGE) was performed according to Laemmli et all. ${ }^{28}$ using gels containing $13 \%$ polyacrylamide (Bio-Rad Laboratories, Hercules, CA, USA), and 0.1\% SDS (Merck). Gels were run on the Mini-Protean II system (BioRad Laboratories) for approximately 45 min at $200 \mathrm{~V}$. For Western blotting the method described by Towbin et al. ${ }^{47}$ was used. The blots were stained with antibodies against cytokeratins, lamins, 7.13 and RN3. Detection was performed using alkaline phosphatase and enhanced chemiluminescence (ECL-kit, Amersham, Amersham, Bucks., UK).

\section{DNA analysis by gel electrophoresis}

Internucleosomal DNA strand breaks were detected by agarose gel electrophoresis. Three different samples of MR65 cells were processed: 1) An experimental sample, consisting of cells treated with CHX for $16 \mathrm{~h}(30 \%$ of the cells were apoptotic, as was determined by morphology after haematoxylin/eosin staining); 2) a negative control sample, consisting of untreated exponentially growing cells; 3) a positive control sample, that was generated by incubating nuclei of exponentially growing cells with micrococcal nuclease, an enzyme that cleaves the DNA into oligonucleosomal 
framents of 200 bp length and multiples therefof. Per sample, $1 \times 10^{7}$ cells were washed in PBS and the pellets were resuspended in lysis buffer containing $10 \mathrm{mM}$ $\mathrm{MgCl}_{2}$ and $0.1 \%$ NP40. After centrifugation of the nuclei, the supernatant was

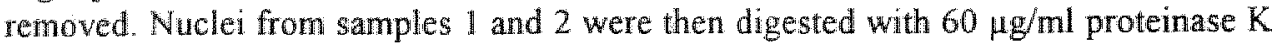
for $2 \mathrm{~h}$ at $55^{\circ} \mathrm{C}$. After $1 \mathrm{~h}, 1 \%$ of $S D S$ was added together with fresh proteinase $\mathrm{K}$. Nuclei of sample 3 were resuspended and treated according to a modification of the protocol described by Compton ${ }^{11}$. Briefly, a $10-\mu 1$ aliquot of $10 \times$ nuclease buffer ( 50 mM Tris pH 7.4,2 $\mathrm{mM} \mathrm{CaCl}_{2}, 2 \mathrm{mM} \mathrm{MgCl}_{2}$ and $1 \mathrm{mM} \mathrm{B-mercaptoethanol)} \mathrm{together}$ with 10 units of micrococcal nuclease (Sigma) was added. The assay volume was brought to $100 \mu \mathrm{l}$ with $\mathrm{H}_{2} \mathrm{O}$, and after gently mixing, the sample was incubated for 45 min at $37^{\circ} \mathrm{C}$. The reaction was terminated by adding $5 \mu \mathrm{l}$ of $0.5 \mathrm{M}$ EDTA, pH $8.0,2 \mu \mathrm{l}$ of $10 \% \mathrm{SDS}$, and $10 \mu \mathrm{l}$ of $20 \mathrm{mg} / \mathrm{ml}$ proteinase $\mathrm{K}$ (Merck). This mixture was then incubated for 60 min at $55^{\circ} \mathrm{C}$.

All samples were extracted with phenol/chloroform. Sodium acetate was added to a final concentration of $0.3 \mathrm{M}$ and the DNA was precipitated by the addition of 2 volumes of absolute thanol at $-20^{\circ} \mathrm{C}$. After washing in $70 \%$ ethanol, the pellets were dissolved in $\mathrm{H}_{2} \mathrm{O}$ and incubated in the presence of $100 \mu \mathrm{g} / \mathrm{ml}$ RNase for $10 \mathrm{~min}$ at RT. Then, samples were applied onto an $1.5 \%$ Tris-acetate agarose gel.

\section{Identification of apoptatic and dead cells}

Apoptotic cells and dead cells were distinguished based on characteristic morphological features, described by several authors amongst which Collins et al." , Farber et all. ${ }^{13}$, Kerr and Harmon ${ }^{23}$, and Wyllie et al. ${ }^{96}$ Briefly, cells displaying chromatin condensation, nuclear disintegration, vacuole formation and membrane blebbing were identified as apoptotic. Cells with cytoplasmic swelling, membrane disruption and disappearance of nuclear chromatin or distribution of the nuclear chromatin in small ill-defined particles, were classified as dead

\section{Results}

\section{Mon-induced apoptosis}

Changes in the nuclear matrix organization were studied in 9 lung cancer cell lines with spontaneously occurring apoptosis. The cells that were identified as apoptotic matched the morphological criteria for apoptosis as described before ${ }^{23,2456}$. Three different antibodies against nuclear matrix associated proteins were used in the indirect immunofluorescence assay, combined with DNA staining using PI. Figure $\mathbb{1}$ 
gives an overview of the staining pattems of antibodies $7.13, \mathrm{RN} 3$ and 2.73 in five representative cell lines. Reactivity with nuclear matrix components was detected in almost all apoptotic cells. In particular, the antibodies 7.13 and RN3 showed a strong, patch-like reactivity pattem, while 2.73 showed a somewhat weaker reaction. A quantification of the reactivity of the three antibodies in apoptotic as well as in dead cells is shown in Table I for each of the cell lines tested. At least one hundred apoptotic or dead cells were examined per cell line.

Nuclear matrix components, especially those recognized by the antibodies 7.13 and $\mathbb{R N} 3$, remained present in cells undergoing apoptosis, while they were generally absent in dead cells. However, especially in cell lines with a relatively high percentage of cell death, part of the dead cells displayed weak 7.13 positivity. The 7.13 signal in these dead cells did not resemble the patch-like staining pattern that was seen in apoptotic cells, but was rather faintly distributed over the whole cytoplasm.

With respect to changes in the cytoskeleton we got the impression that different mechanisms govern this structure during apoptosis and cell death. This was particularly evident in the MR65 cell line, where cytokeratin filaments seemed to aggregate during spontaneous apoptosis and to disappear in dead cells (data not shown).

Table I. Reactivity of antibodies against nuclear matrix proteins with non-induced apoptofic and dead cells in warious lung cancer cell lines ${ }^{a}$.

\begin{tabular}{|c|c|c|c|c|c|c|c|}
\hline \multirow[b]{2}{*}{ Type } & \multirow[b]{2}{*}{ Cell line } & \multicolumn{3}{|c|}{$\begin{array}{l}\text { Apoptatic cells } \\
\% \text { positivity for }\end{array}$} & \multicolumn{3}{|c|}{$\begin{array}{l}\text { Dead cells } \\
\% \text { positivity for }\end{array}$} \\
\hline & & 7.13 & 2.73 & RiN3 & 7.13 & 2.73 & RN3 \\
\hline NSSCLC & MR65 & 93 & 70 & 91 & 4 & 6 & 4 \\
\hline NSCLC & $\mathrm{H} 23$ & 98 & 80 & 97 & 6 & 7 & 4 \\
\hline NSCLC & $\mathrm{H} 460$ & 91 & 83 & 82 & 2 & 3 & 5 \\
\hline NSSCLC & 41155 & 79 & 67 & 8.2 & 13 & 6 & 1 \\
\hline NSCLC & 1810 & 68 & 73 & 71 & 30 & 9 & 3 \\
\hline SCLC & $\mathrm{NCl}-\mathrm{H} 82$ & 71 & 6.4 & 84 & 2 & 2 & 2 \\
\hline SCLC & $\mathrm{NL}-S \mathrm{CLC} 2$ & 74 & 47 & 81 & 6 & 2 & 1 \\
\hline SCLC & $\mathrm{SCLC} 21 \mathrm{H}$ & 91 & nod. & 91 & 26 & n.d. & 1 \\
\hline SCLC & GLC-1 & 55 & 64 & 73 & 42 & 10 & 6 \\
\hline
\end{tabular}

Vital, non apoptotic cells were virtualy all positive for the nuclear antigens tested. n.d.. not determined 
Induction of apoptosis

A difficulty in the experiments described above was the rare occurrence of spontaneous apoptosis $(0.5-5 \%$ of the cells). To be able to study changes in the nuclear matrix and the cytoskeleton in more detail, apoptosis was induced in the NSCLC cell line MR65 with cycloheximide (CHX). To elaborate on the structural changes in the mucleoskeleton we selected a set of antibodies that recognize different fractions of this cellular compartment. Antibodies $\mathrm{LN} 43$ and $41 \mathrm{CC} 4$ were used to study the nuclear lamina, antibody 7.13 to examine the fibrogramular matrix and antibody Ki67 to study the reorganization of the nucleolar matrix. Cytoskeletal changes were studied using an anti-cytokeratin antibody.

In exponentially growing non-treated cultures of MR65 cells, apoptotic cells were consistently observed at low frequency, i.e. I to $5 \%$. By overnight incubation with CHX, we observed that the number of apoptotic cells dramatically increased up to $40 \%$ (Fig. 2). The degree of apoptosis was a dose-dependent process. Apoptosis was induced by every tested concentration of CHX between 1 and $1000 \mu \mathrm{g} / \mathrm{ml}$ (data not shown). Since the frequency of apoptotic cells obtained in this way was high, this induction assay was used to further characterize the temporal changes in the cyto- and karyoskeleton in relation to the different stages of the apoptotic process. To this end, MR65 cells were incubated with CHX, and cell samples were harvested every two hours. In Figure 3, the vitality and percentage of apoptotic cells (as determined from both cellular morphology (HE staining) and nuclear morphology (PI staining)) are given. In the presence of CHX, an increase is seen in the number of cells showing morphological features of apoptosis, such as nuclear disintegration, vacuole formation, chromatin condensation and membrane blebbing. After $16 \mathrm{~h}$, the vitality started to decrease. Gel electrophoresis of MR65 treated with $\mathrm{CHX}$ showed no DNA laddering pattern typical for apoptotic cells, in contrast to the positive control (Fig. 4).

\section{In situ nick trans/ation}

All cells displaying morphological criteria for apoptosis were positive in the in situ nick translation assay. They showed a positive signal that was clearly discernible from the background signal (Fig. 5). Normal interphase cells and mitotic cells were negative, showing only the background signal. Dead cells showed strong in situ nick labeling. 

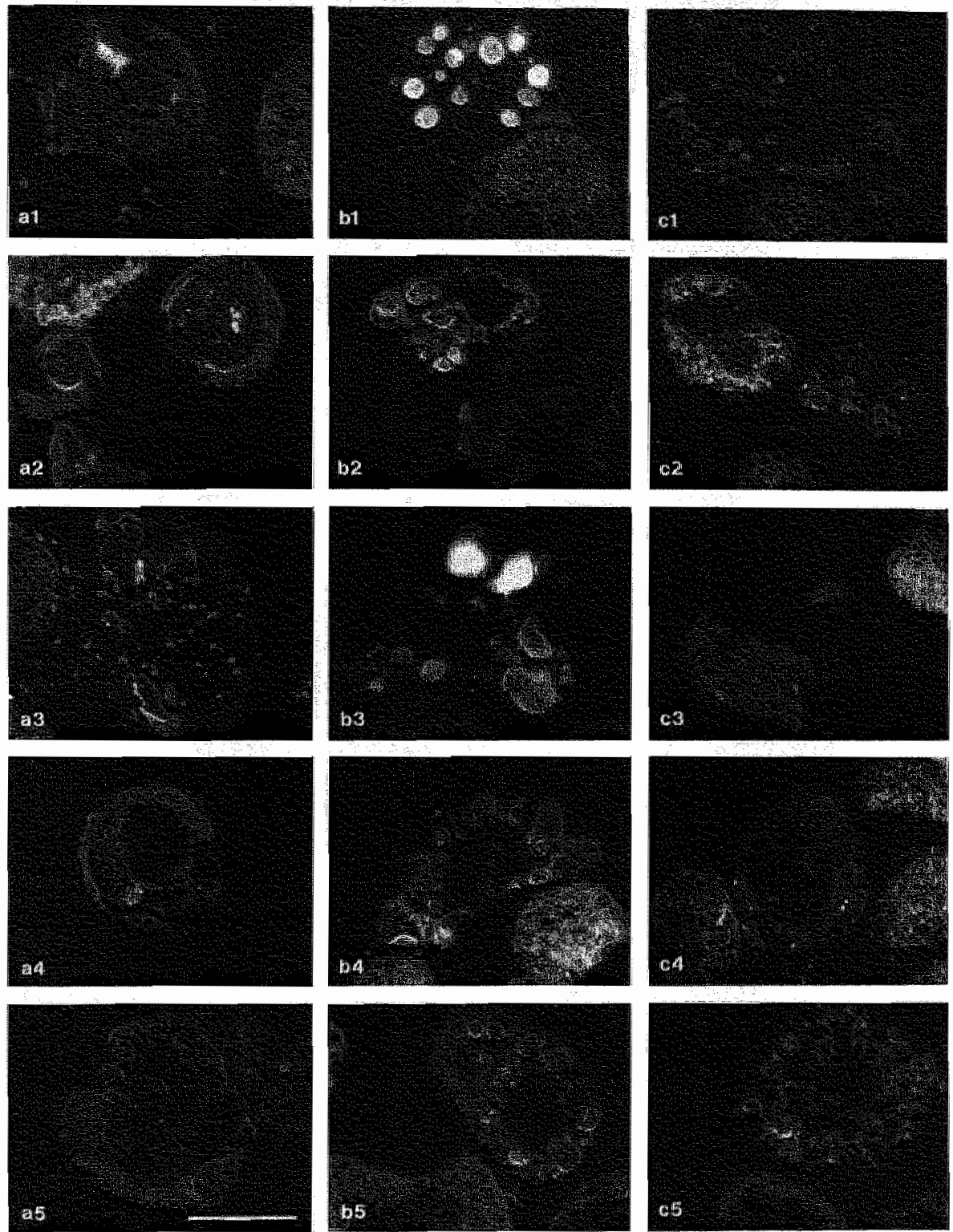

Figure 1. Spontaneously occurring apoptotic cells in exponentially growing cell lines MR65 (1), $\mathrm{NCl}$ H460 (2), NClH23 (3), NL-SCLC2 (4) and NCl-H82 (5), stained with antibodies 7.13 (a), RN3 (b) and 2.73 (c). - Bar $10 \mu \mathrm{m}$. 


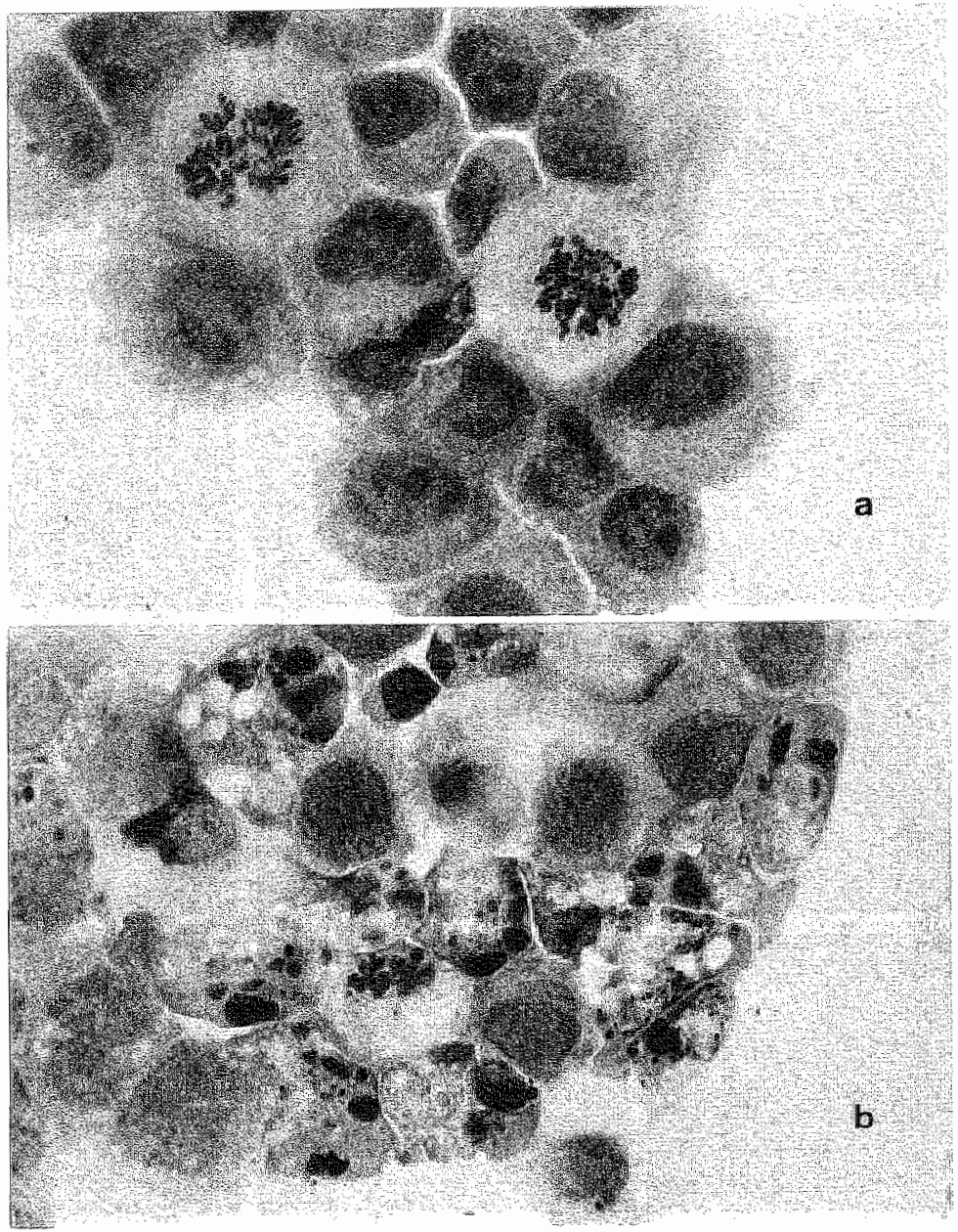

Figure 2. Exponentially growing MR65 cells before (a) and 16 h after (b) the addition of cycloheximide. - Bar 10 jum.

\section{Cytoskeletal changes}

The expression of cytoskeletal antigens was monitored in apoptotic as well as in vital interphase cells and dead cells. In general, most of the apoptotic cells showed a deviant expression pattern compared to viable cells. In vital interphase cells, the cytokeratin antibody RCK 102 yielded a filamentous immunostaining pattern, mainly 
localized around the nucleus (Fig. 6a). Aggregated structures with clusters of filaments still attached to the nucleus but located in the cytoplasm were found in part of the apoptotic cells (Fig. 6b), next to a more or less 'normal' filamentous pattern.

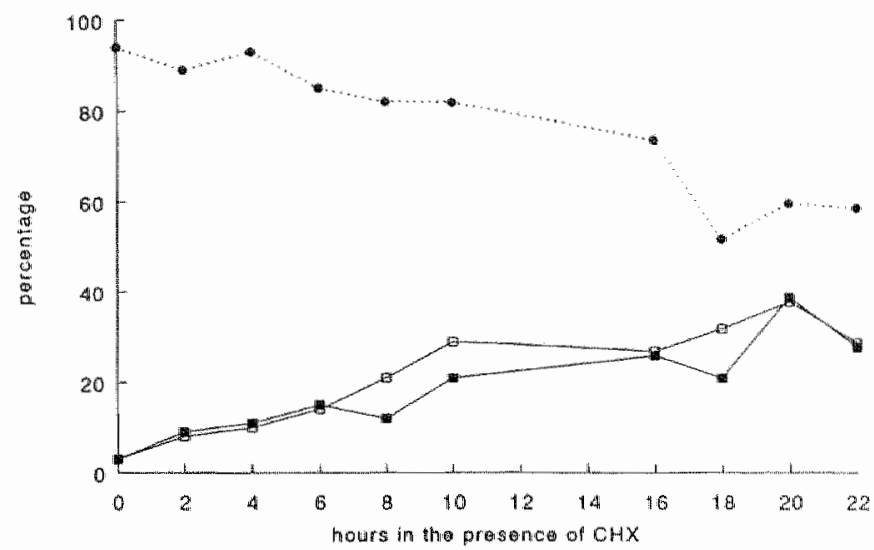

Figure 3. Percentage of vital and $\mathrm{CHX}$-induced apoptotic cells during cycloheximide treatment of MR65 cells. …..... percentage of vital cells: $s_{i} \ldots$ morphology on HE-stained slides; - _ : percentage of apoptotic cells as determined from nuclear morphology on Pl-stained slides. $X$ axis: hours of cycloheximide treatment.

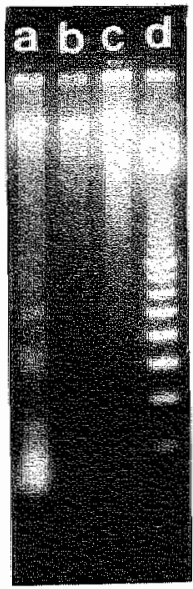

Filgure 4. DNA gel electrophoresis of micrococcal nuclease treated DNA from exponentialy growing untreated MR65 calls (fane a), undigested DNA from untreated MR65 cells (lane b), DNA from 16 h cychoheximide treated MR65 conts (lane c) and to0 bp marker (lane d). 


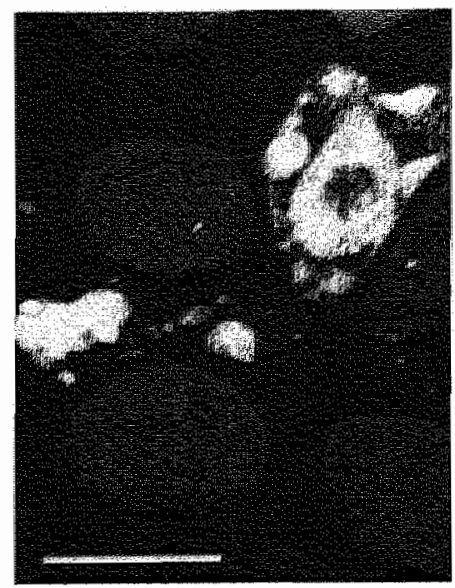

Figure 5. Confocal scanning laser microscopy of in situ nick translation on MR65 cells, treated with cycloheximide for 16 hours. - Red: DNA staining. - Green: in situ nick translation signal. Note that only apoptotic figures show incorporation of biotinylated dUTP. - Bar $10 \mu \mathrm{m}$.

After $16 \mathrm{~h}$ of CHX, however, the majority of apoptotic cells was either totally negative for cytokeratin $(50 \%)$ or showed dot-like aggregates located all over the cytoplasm (approximately 40\%; Fig. 6c). Some of the apoptotic cells showed a combination of these expression patterns at the same time (filamentous/aggregated or aggregated/dot-like), usually with one of these patterns dominating. Dead cells showed practically no cytokeratin immunostaining.
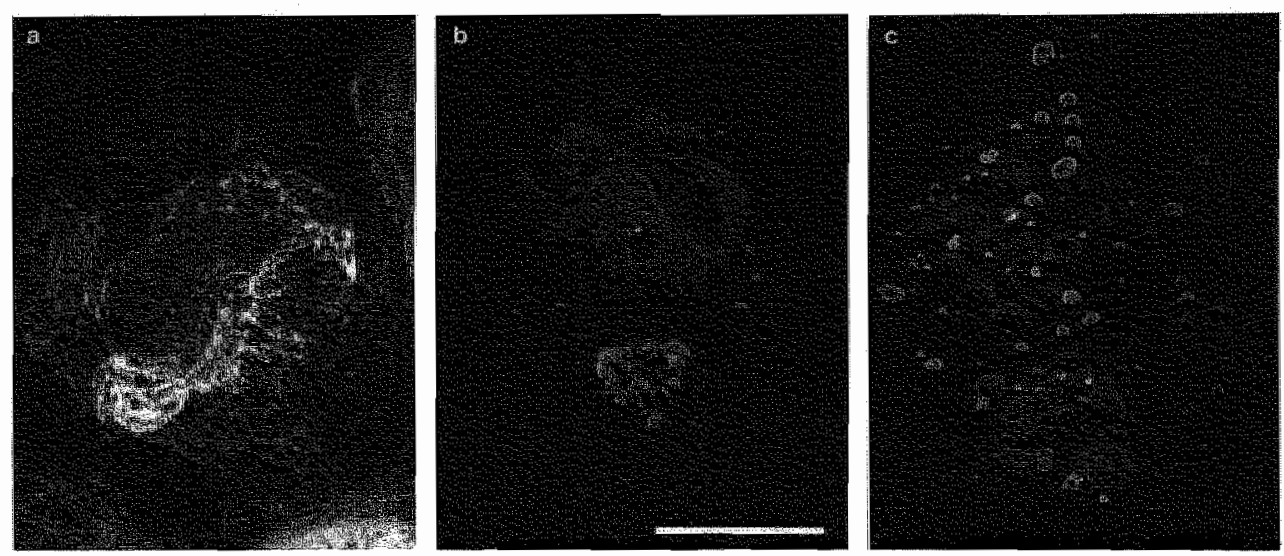

Figure 6. Cytokeratin expression as visualized by confocal scanning laser microscopy after immunostaining with the antibody RCK102 (green) and PI staining for DNA (red). - a. Normal filamentous pattern in a vital prophase cell. - b. Aggregated pattem in a $\mathrm{CHX}$-induced apoptotic cell. - c. Dot-like pattern in a $\mathrm{CHX}$-induced apoptotic cell. - Bar $10 \mu \mathrm{m}$. 


\section{Nucleoskeletal changes}

The distribution of nucleoskeletal components was studied with antibodies that stain either the nuclear lamina, the fibrogranular matrix or the nucleolar matrix.

The LN43 antibody, directed against B-type lamin, showed a homogenous staining of the nuclear lamina and sometimes perinuclear aggregates in vital interphase cells. Apoptotic cells, though sometimes expressing a nomal B-type lamin pattem or an aggregated pattern near the fragmented DNA, were mainly negative. Ten hours after CHX administration, the number of apoptotic cells lacking B-type lamin expression increased to almost $100 \%$. Some dead cells displayed a faint staining reaction with a normal or aggregated pattern but the majority was negative for B-type lamin.

In vital interphase cells, the expression of A-type lamins (A/C), visualized by the $41 \mathrm{CC} 4$ antibody, resembled the perinuclear B-type lamin pattern. Apoptotic cells were mainly negative, but some cells showed a faint normal staining pattern or a clustering of A-type lamins near the fragmented DNA. The frequency of A-type lamin-negative apoptotic cells increased during incubation with $\mathrm{CHX}$. From the dead cells only a few percent expressed a faint normal or aggregated pattem; the rest was negative.

In vital interphase cells the $13 \mathrm{kDa} D$-protein of $U_{1} R N P$ nuclear matrix particles, detected by antibody 7.13 , showed a diffusely speckled nuclear staining pattern, with exclusion of the nucleoli (Fig. $7 \mathrm{a}$ ).
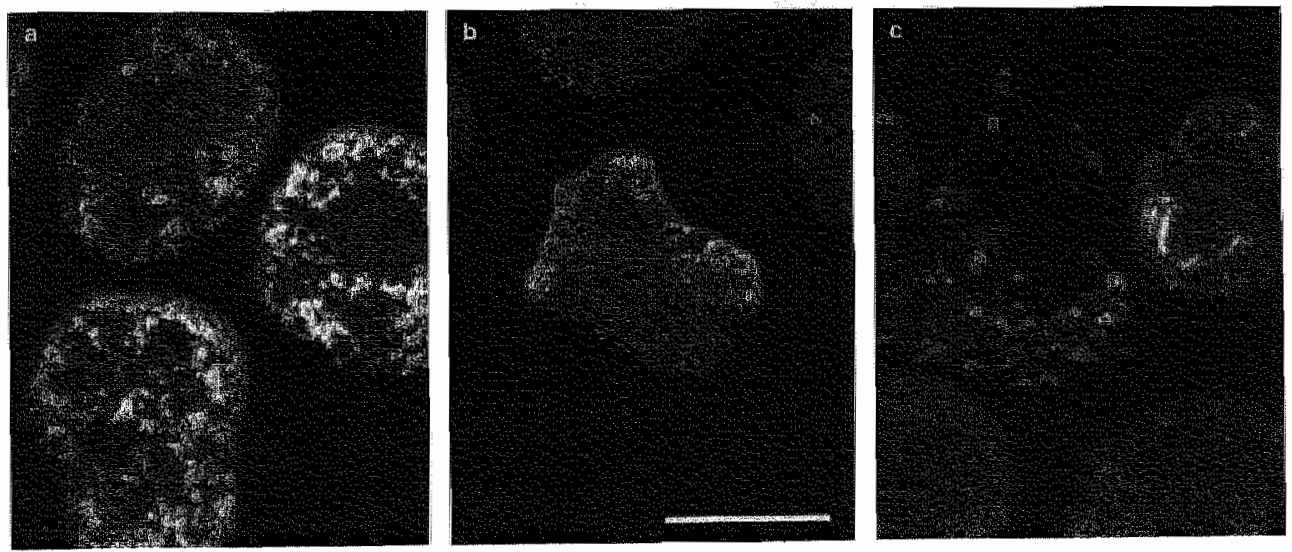

Figure 7. Expression of the $13 \mathrm{kDa}$ nuclear matrix protein as visualized by confocal scanning laseir microscopy after immunostaining with the antibody 7.13 (green) and PI staining for DNA (red).

- a. Normal pattern in vital interphase cells. - b. Patch-like staining pattern in a $\mathrm{CHX}$-induced apoptotic cell. - c. Dot-like and patch-fike staining pattern in CHXainduced apoptotic cells. - Bar $10 \mu \mathrm{m}$. 
In some apoptotic cells, the normal expression pattern was present but most cells (20$50 \%$ ) showed a patch-like staining complementary to the DNA (Fig. 7b). During longer incubation with $\mathrm{CHX}$, the 7.13 immunostaining pattern changed into smaller aggregated structures (Fig. 7c). Dead cells, if not negative for 7.13 , showed a very faint, speckled pattern in the nucleus.

The Ki67-antigen is located in the nucleoli in vital interphase cells. A small percentage $(5-10 \%)$ of the interphase cells was negative for the Ki67-antigen. During apoptosis, nucleoli disintegrated, and as a result the Ki67-antigen was scattered throughout the nucleus in a 'multi-spot' pattern. This pattern, however, disappeared very rapidly, and the majority of the apoptotic cells lacked Ki67-antigen immunoreactivity. As became evident from their nuclear morphology, these Ki67-antigen negative cells were late-apoptotic. Virtually all dead cells were Ki67-antigen negative.

A general summary of the immunocytochemical data is given in Table II. The observed labeling patterns for the various antibodies were not artificially introduced by protein synthesis inhibition, since similar changes were observed in spontaneously occurring apoptotic cells.

Table II. Generalized reactivity patterns of various antibodies to cytoskeletal and nucleo-skeletal proteins in vilall dead and apoptotic MR65 cells.

\begin{tabular}{lccc}
\hline & vital & dead & apoptotic \\
\hline ISNT & - & + & + \\
cytokeratin & + & - & $+1-$ \\
7.13 & + & & + \\
Ki6.7-Ag & + & & - \\
lamins AV & + & & - \\
lamin B & + & & - \\
\hline
\end{tabular}

Percentage of positive cells: + : more than $90 \%$ positive: - less than $5 \%$ positive; $+100-50 \%$ positive.

The results obtained by immunocytochemistry were confirmed by gel electrophoresis with subsequent Western blotting (Fig. 8). After CHX treatment, no quantitative changes in nuclear matrix proteins could be detected (Figs. 8a,b), although the RN3 protein showed a slight degradation band (Fig 8 b). In contrast, clear lamin degradation was observed after CHX treatment (Fig. 8e), while cytokeratins either completely 
(cytokeratin 19; Fig. 8c) or partly (cytokeratin 8; Fig. 8d) disappeared. No indications for accumulation of high-molecular weight proteins after $\mathrm{CHX}$ treatment were found.

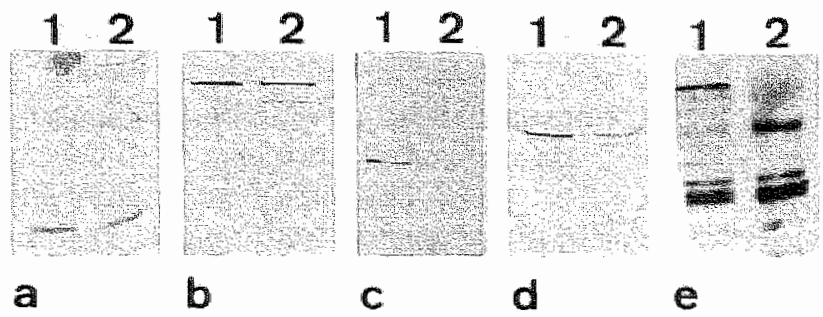

Figure 8. Western blotting of MR65 cells untrealled (lanes 1) or treated (lanes 2) with cycloheximide for 16 th. The firmuno-blots were incubated with (a) 7.13 , recognizing the $13 \mathrm{kDa}$-protein of U,RNP particles, (b) RN3, detecting the $80 \mathrm{kDa}$ protein of the Ku-

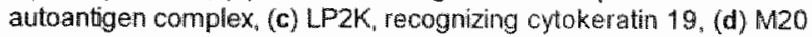
for cytokeratin $8_{1}$ (e) $133 \mathrm{~A} 2$ for lamin A. Note that the cytokeratins and lamin A are (partially) lost in apoptotic cells.

\section{Three parameter analysis}

Since the presence of the 7.13 antigen and, to a lesser extent, the presence of aggregated cytokeratin in combination with positive reaction in the in situ nick labeling assay seems to discriminate between dead and apoptotic cells, we developed a protocol for a simultaneous analysis of DNA, ISNT and cytokeratin or 7.13 antigen expression using flow cytometry. Figure 9 shows the feasibility of this approach for cells stained in suspension, where the combined ISNT signal $(x-a x i s)$ and cytokeratin or 7.13 exptession signal ( $y$-axis) of single intact cells before and after CHX administration ane depicted. From Figure $9 \mathrm{a}$ it appears that the majority of cells without CHX treatment is merely ISNT negative and cytokeratin positive (90\%). A small population of either cytokeratin-positive/ISNT- positive (1\%) or cytokeratin-negative/1SNT-positive cells $(3 \%)$ is observed. After administration of $\mathrm{CHX}$ the frequency of cytokeratin-positive, ISNT-positive cells increased from $1 \%$ to $5 \%$, while $48 \%$ of the cells was cytokeratinnegative, ISNT- positive (Fig. 9b). In a separate experiment, the combined ISNT ( $\mathrm{x}$ axis) and 7.13 (y-axis) staining of single intact cells was performed after administration of CHX. The results are shown in Figure 90 . In an exponentially growing culture of MR65 cells the majority of the cells $(96 \%)$ is 7.13 positive and does not display an ISNT signal. A small minority of cells $(3 \%)$ is positive for both criteria (data not shown). When cells were incubated overnight with $\mathrm{CHX}$, a dramatic increase (from 
$3 \%$ to $41 \%$ ) of the latter subpopulation of cells was observed. Simultaneously, a slight increase (from $0.2 \%$ to $3.5 \%$ ) in ISNT-positive, 7.13-negative (i.e. dead) cells was seen. In this experiment, a reduced background staining was measured as evidenced by different quadrant settings.
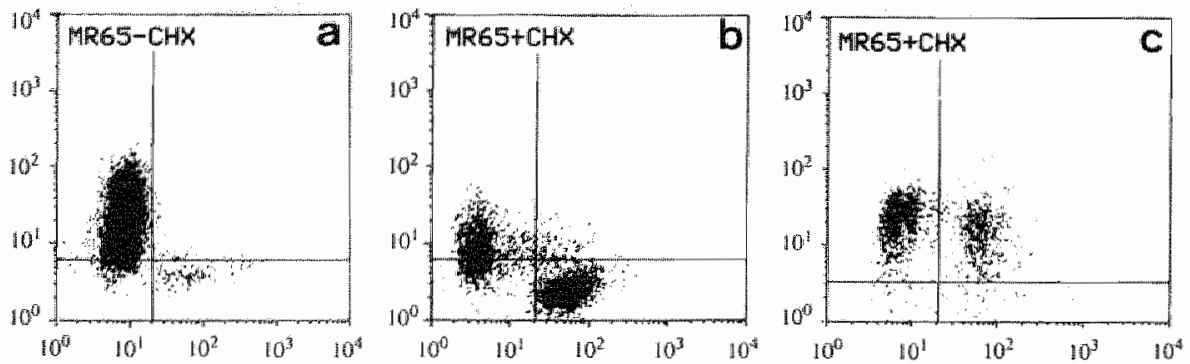

Figure 8. Three parameter flow cytometric analysis of in situ nick translation (ISNT) combined with cytokeratin 7.13 and DNA staining in exponentially growing MR65 cells (a) and MR65 cells treated with cycloheximide for $16 \mathrm{~h}(b, c)$. Cytograms of ISNT signal (x-axis) wersus cytokeratin expression ( $y$-axis) $(a, b)$ and $\|$ SNT signal ( $x$-axis) versus 7.13 expression ( $y$-axis) (c). Quadrant settings were based on the negative control.

\section{Discussion}

In this study we have examined the reorganization of the cytoskeletal and nucleoskeletal matrix during the process of apoptosis. For this purpose we have studied spontaneously occurring apoptosis in several cell lines and, more specifically, cycloheximide induced apoptosis in the NSCLC cell line MR65. Administration of CHX appeared to increase the number of MR65 cells with morphological features of apoptosis. Staining patterns of antibodies observed in induced apoptotic cells were identical to the staining patterns in spontaneously occurring apoptotic cells, indicating that these patterns were not artificially induced by the inhibition of protein synthesis. The cells that were morphologically characterized as being apoptotic were all positive in the in situ nick translation assay. DNA gel electrophoresis of samples treated with $\mathrm{CHX}$ did however not reveal the laddering pattern which is typical for apoptotic cells. Recently, Walker et al. ${ }^{52}$ described a two-stage DNA fragmentation process in apoptotic cells. Only the first stage, in which the DNA is fragmented into 50 to $300 \mathrm{~kb}$ fragments, seemed to be essential for apoptosis and at this point, condensation of the chromatin already occurs. Several authors have now reported the absence of specific 
internucleosomal cleavage upon apoptosis in different epithelial and mesenchymal cell lines. Instead of oligonucleosomal fragments of $200 \mathrm{bp}$ and multiples thereof, the DNA of apoptotic cells was found to be degraded into much larger fragments, varying from 30 to $300 \mathrm{kbp}^{8,10,37,39,48}$.

The effect of CHX seems to be cell type dependent. Several authors describe an apoptosis inducing effect of $\mathrm{CHX}^{14,18,58}$, whereas others report an apoptosis inhibiting action ${ }^{16}$. However, in all these studies, different cell types as well as different doses of CHX (ranging from $1-50 \mu \mathrm{g} / \mathrm{ml}$ ) were used. In our study, the degree of apoptosis in MR65 cells appeared to be a dose-dependent process, with every tested concentration of CHX inducing programmed cell death. Since CHX is known to inhibit protein synthesis, the proteins required for the apoptotic process must be already present in some cell types, their action being suppressed by regulatory proteins. In line with this assumption is the observation by Bertrand et al. ${ }^{4}$ that by blocking protein phoshorylation apoptosis can be triggered, suggesting a delicate balance between inducing and inhibiting signals. Cohen et al. ${ }^{9}$ explained this phenomenon by the presence of 'death genes' that have already been expressed in the cell, but are kept inactive by inhibitory proteins with short half-lives. Interference with protein synthesis would unblock the "death program" as the inhibitors decay. Robaye et al. ${ }^{22}$ found that a combination of tumor necrosis factor and CHX induced apoptosis in a synergistic fashion, and ascribed this to the proteolysis of anti-apoptotic proteins together with inhibition of their replenishment by de novo protein synthesis.

Our study of changes in the nuclear matrix organization of apoptotic cells in nine different cell lines indicated a persistence of nuclear matrix-associated proteins during programmed cell death. Our immunocytochemical data are in concordance with the ultrastructural observations of Arends et al. ${ }^{2}$, who found that apoptotic nuclei contained a pore complex lamina, a fine nuclear-matrix fiber meshwork and residual nucleolar bodies. The different antibodies against nuclear matrix components showed persistent staining patterns. The retained staining pattern with monoclonal antibodies 7.13 and 2.73 , both directed against one of the nine protein constituents of the $U_{1}$ snRNP particle, in apoptotic cells revealed that these nuclear matrix associated constituents, that play a role in RNA splicing ${ }^{27.29}$, are not (completely) degraded. The biological significance of the preservation of snRNP particles in apoptotic cells is not clear, although evidence exists that RNA synthesis is required for apoptosis ${ }^{51,55}$. In contrast, Miller et al..$^{35}$ described solubilization of the nuclear matrix in MCF7 cells and suggested that this phenomenon is a general process during apoptosis. However, the antibodies used in their study are directed against different nuclear matrix structures than the antibodies we used. Therefore, a likely explanation for the discrepancies between the study of Arends et al $^{2}{ }^{2}$ and our study on the one hand, and the study of Miller et al. ${ }^{35}$ on the other hand, would be solubilization and release of specific nuclear matrix proteins rather than complete degradation of the nuclear matrix during apoptosis. 
To investigate the kinetics of the process in more detail, apoptosis was induced by cycloheximide in the NSCLC cell line MR65. In addition to the fibrogramular matrix, changes in the nuclear lamina, the nucleolar matrix and the cytoskeleton were monitored. Immunocylochemical staining patterts suggest that in carly apoptotic cells the cytokeratin filaments rapidly aggregate and that at later stages these cytoskeletal constituents depolymerize completely. This was confirmed by Western blotting, where a clear degradation of cytokeratin was observed after CHX treatment. This phenomenon might be directly linked to membrane blebbing, a characteristic feature of apoptosis. Allen' suggested that membrane blebbing can be the result of loss of cytoskelletal control, which is in concordance with the observed aggregated staining patterns for cytokeratin in apoptotic cells. In contrast, membrane blebbing is also observed as a consequence of rapid reorganization of cytoskeletal elements due to shape change, for instance during mitosis'. In mitotic cells, we observed an intact filamentous cytokeratin network as is shown in Figure 6a. The enzyme tissue transglutaminase, which is involved in the stabilization of proteins both in the cytoskeleton and at the cell surface, is known to play a role in apoptosis, particularly in the formation of the apoptotic envelopes ${ }^{45.25}$. However, we found no evidence for a mediating role of transglutaminase in the clustering of cytokeratins, since no high molecular weight cross-linked cytokeratin fragments were observed using Western blotting. Using flow cytometry, random loss of cytokeratin- positive cells was seen in all stages of the cell cycle (data not shown). This suggests a phase-independent induction of apoptosis by CHX. Similarly, Gorczyca el al. ${ }^{18}$ reported a triggering of apoptosis by $\mathrm{CHX}$ that was not selective towards one particular phase in the cell cycle.

The nucleolar matrix associated Ki67-antigen and the nuclear membrane associated Aand B-type lamins (or rather the epitopes recognized on these proteins by the antibodies used) are rapidly lost after onset of apoptosis. For lamin $A$, this was confirmed by Western blotting (Fig $8 \mathrm{e}$ ). Lazebnik et al. ${ }^{31}$ report disassembly of the nucllear lamina as a characteristic feature of apoptosis. In their study, lamins $A$ and $B_{2}$ in apoptotic cells were either found to be dispersed throughout the cytoplasm, or were undetectable. Also, Oberhammer al ${ }^{28}$ described breakdown of the nuclear lamina during apoptosis. Since inmunoreactivity of these markers is also absent in dead cells, the expression of the $\mathrm{Ki} 67-\mathrm{Ag}$ and of the $\mathrm{A}$ - and B-type lamins is not conclusive in discriminating between these two states of cell termination. In contrast, the $13 \mathrm{kD} \mathrm{U}, \mathrm{snR} N \mathrm{~N}$ associated protein appears to remain present in the induced apoptotic cell, as identified both by immunocytochemistry and Western blotting. The staining patterns observed in the induced apoptotic cells were identical to the patterns observed in spontaneous apoptotic cells, while 7.13 immunoreactivity was lost in dead cells. Therefore, 7.13 immunoreactivity discriminates between dead and apoptotic cells.

From the results in Table II and in Figure 9 it is evident that a combination of antibody 7.13 or cytokeratin with ISNT can discriminate between vital, dead and apoptotic cells. Experiments proved that a triple detection procedure for 7.13 or cytokeratin, 
ISNT and DNA is feasible on cytospins as well as on single cell suspensions analyzed by flow cytometry. In a combination of immunostaining with antibody 7.13 , PI for DNA, and ISNT, three different subpopulations of cells can be distinguished: 1) cells that are ISNT negative and 7.13 positive (vital); 2) cells that are ISNT positive and 7.13 negative (dead) and 3) cells that are ISNT positive and 7.13 positive (apoptotic). According to immunocytochemical analysis of this sample, the latter group of cells shows morphological features typical of apoptosis. In contrast, morphological structures typical of dead cells are found in ISNT positive/7.13 negative cells. Likewise, in the triple staining procedure for ISNT, cytokeratin and DNA, three different subpopulations can be distinguished: 1) cells that are ISNT negative and cytokeratin positive (vital); 2) cells that are ISNT positive and cytokeratin negative (dead or apoptotic) and 3) cells that are ISNT positive and cytokeratin positive (apoptotic). The number of apoptotic cells with aggregated cytokeratin expression patterns, as determined by microscopical analysis of cytospin preparations, corresponded with the number of cells counted in the latter subpopulation. The majority of the apoptotic cells, however, is cytokeratin negative by flow cytometric analysis, and is found in the same subpopulation as the dead cells. Most likely, the very small cytokeratin aggregates, microscopically observed as a speckled pattern, are lost during fixation of cells. Thus, in a three parameter analysis using cytokeratin, ISNT and DNA, only part of the apoptotic cells can be identified.

Immunocytochemical staining against the 7.13 antigen, combined with an in situ nick translation assay and staining of the DNA, seems to be the most promising approach in the detection of apoptosis. In this way, dead cells and apoptotic cells can be discriminated. However, at later stages during the process, apoptotic cells can undergo secondary necrosis, at which state the membrane integrity is completely lost. Recent evidence suggests that secondary necrosis is a very late phenomenon during apoptosis. Koopman et al. ${ }^{26}$ showed that early during apoptosis membrane polarity is lost as evidenced by exposure of phosphatidylserine residues at the cytoplasmic outer membrane, while the membrane integrity is still preserved. Preliminary experiments using the MR65 cell line indicate that the vast majority of apoptotic cells is still viable and not necrotic as determined by propidium iodide exclusion, but showed loss of membrane polarity and chromatin fragmentation. By the time membrane integrity is lost, these apoptotic cells completely disintegrate into smaller apoptotic bodies and vesicles, which can be easily excluded from the flow cytometric analysis by gating on size parameters. Using flow cytometry, simultaneous measurement of the DNA content of a sample furthermore enables the study of cell cycle phase dependence of apoptosis induction. For samples obtained from solid tumors, this approach also allows separation of tumor and non-tumor cells based on ploidy.

In conclusion, the nuclear matrix and the cytoskeleton undergo evident changes during the apoptotic process. Specific components of the nuclear matrix and, in early apoptotic phases, of the cytoskeleton, remain present in the cell. The detection of these components is helpful in identifying apoptosis in a cell population. Based on the 


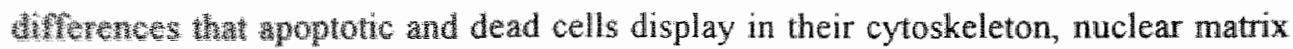

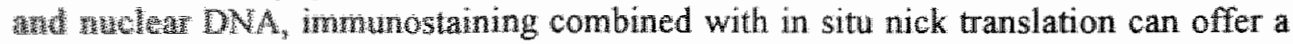
switum the problen of discriminating between vital, dead and apoptotic cells.

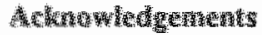

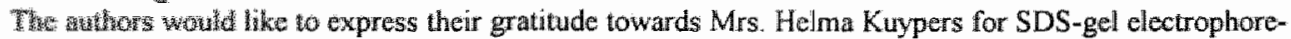

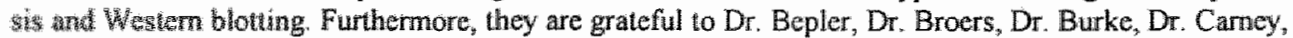
De. Gropz, Dr. Hoch, Dr. E.B. Lane, Dr. de Leij, Dr. Linnoila, Dr. van Muyen, and Dr. Raymond for

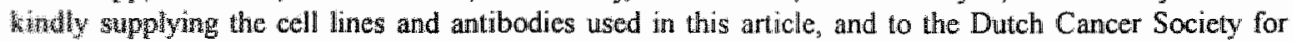
sapporting this study (Grant no. IKL90-01). 


\section{References}

1 Allen TD: Ultrastructural aspects of cell death. In. Perspectives on Mammatian Cell Death. Potten CS (ed), pp 39-65, Oxford University Press, Oxford (1987).

2 Arends MJ, Morris RG, Wyllie AH: Apoptosis. The role of the endonuclease. Am J Pathol 136:593-608 (1990).

3 Arends MJ MoGregor A.H, Wyllie AH: Apoptosis is inversely related to necrosis and determines net growth in tumors bearing contitutively expressed myc, ras and HPV oncogenes. Am J Pathol 144:1045-1057 (1994).

Bertrand $\mathrm{R}$, Solary $\mathrm{E}, \mathrm{O}^{\prime}$ Connor $\mathrm{P}$, Kohn KW, Pommier $\mathrm{Y}$ : Induction of a common pathway of apoptosis by staurosporine. Exp Cell Res 211:314-321 (1994).

Billings PB, Allen RW, Jensen FC, Hoch SO: Anti-RNP monoclonal antibodies derived from a mouse strain with lupus-like autoimmunity. J Immun 128:1 176-1180 (1982).

Bissonnette RP, Echeverri F, Mahboubi A, Green DR: Apoptotic cell death induced by c-myc is inhibited by bol-2. Nature 359:552-556 (1992).

7 Buja LM, Eigenbrodt M, Eigenbrodt EH: Apoptosis and necrosis. Basic types and mechanisms of cell death. Arch Parhol Lab Med 117:1208-1214 (1993).

Cohen GM, Sun X-M, Snowden T, Dinsdale D, Skilleter DN: Key morphological features of apoptosis may occur in the absence of internucleosomal DNA fragmentation. Biochem $J$ 286:331-334(1992)

Cohen JJ, Duke RC, Fadok VA, Sellins KS: Apoptosis and programmed cell death in immunity. Annu Rev Immunol 10:267-293 (1992).

Collins RJ, Harmon BV, Gobé GC, Kerr JFR: Internucleosomal DNA cleavage should not be the sole criterion for identifying apoptosis. In I Radiar Biol 61:451-453 (1992).

11 Compion MM: Development of an apoptosis endonuclease assay. DNA and Cell Biology 10:133-141 (1991).

12. Evan GI, Wyllie AFI, Gilbert CS, Littlewood TD, Land H, Brooks M, Waters CM, Penn LZ, Hancock DC: Induction of apoptosis in fibroblasts by c-myc protein. Cell 69:119-128 (1992).

Farber JL: Biology of disease: membrane injury and calcium homeostasis in the pathogenesis of coagulative necrosis. Lab Invest 47:114-123 (1982).

Fukuda K, Kojiro M, Chiu J-F: Demonstration of extensive chromatin cleavage in transpianted morris hepatoma 7777 tissuc: apoptosis or necrosis?' Am J Pahol 142:935-946 (1993).

Fukuda K, Kojiro M, Chiu J-F. Induction of appoptosis by transforming growth factor-beta I in the rat hepatoma cell line McA-RH7777: a possible association with tissue transglutaminase expression. Hepatology 18:945-953 (1993).

Gold R, Schmied M, Rothe G, Zischler H, Breitschopr H, Wekerle H, Lassmann H: Detection of DNA fragmentation in apoptosis: application of in situ nick translation to cell culture systems and tissue sections. J Histochem Cytochem 41:1023-1030 (1.993).

Goldman AS, Baker MK, Piddington R, Herold R: Inhibition of programmed cell death in mouse
embryonic palate in vitro by cortisol and phenytom: receptor involvement and requirement of protein synthesis. Proc Soc Exp Biol Med 174:239-243 (1983).

Gorczyca W, Brumo S, Darzynkiewicz $\mathbb{R J}$, Gong J, Darzynkicwicz Z. DNA strand breaks occurring during apoptosis. Their early in situ detection by the teminal deoxynucleotidyl transferase and nick translation assays and prevention by serine protease inhibitors. Int J Oncol 1:639-648 (1992). 
19 Hengartner MO, Ellis RE, Horvitz HR: Caenorhabditis elegans gene ced-9 protects cells from programmed cell death. Noture 356:494-499 (1992).

20 Hockenbery DM, Oltvai ZN, Yin X-M, Milliman CL, Korsmeyer SJ: Bcl-2 functions in an atrtioxidant pathway to prevent apoptosis. Cell 75:241-251 (1993).

21 Hollstein M, Sidransky D, Vogelstein B, Harris C: P53 mutations in human cancers. Science 253:49-53 (1991).

22 Hoxák P, Sasseville AMJ, Raymond $Y$, Cook PR: Lamin proteins form an internal nucleoskeleton as well as a peripheral lamina in human cells. J Cell Sci 108:635-644 (1995).

23 Kerr JFR, Harmon BV: Definition and incidence of apoptosis: an historical perspective In: Apoptosis: the Molecular Basis of Cell Death. Tomei LD, Cope FD (eds), pp 5-29. Cold Spring Harbor Laboratory Press, New York (1991).

24 Kerr JFR, Wyllie AH, Currie AR: Apoptosis: A basic biological phenomenon with wide-ranging implications in tissue kinetics. Br.JCancer 26:239-257(1972).

25 Knight $\mathrm{RL}$, Hand D, Piacentini M, Grifin M: Characterization of the transglutaminase-mediated large molecular weight polymer from rat liver, its relationship to apoptosis. Eur I Cell Biol $60: 210-216(1993)$.

26 Koopman G, Reutelingsperger CPM, Kuijten GAM, Keehnen RMJ, Pals ST, van Oers MHJ: Annexin $V$ for flow cytometric detection of phosphatidylserine expression on $B$ cells undergoing apoptosís. Blood 84:1415 1420 (1994).

27 Krainer AR, Maniatis T: Multiple factors including the small nuclear ribonucleoproteins U1 and U2 are necessary for prem mNA splicing in vitro. Cell 42:725-736 (1985)

28 Laemmli UK: Cleavage of structural proteins during the assembly of the head of bacteriophage T4. Nature 227:680-685(1970).

29 Lamond AI, Carmo-Fonseca M: Localisation of splicing snRNPS in mammalian cells. Mol Biol Rep 18:127-133(1993)

30 Lane EB, Bartek J, Purkis PE, Leigh IM: Keratin antigens in differentiating skin. Ann NY Acad Sci 455:241-258 (1985)

31 Lazchnik YA, Cole S, Cooke CA, Nelson WG, Earnshaw WC: Nuclear events of apoptosis in vitro in cell-free mitotic extracts: a model system for aualysis of the active phase of apoptosis. $J$ Cell Biol 123:7-22 (1993)

32 Lockskin RA, Zakeri Z: Progranmed cell death and apoptosis. In: Curren Commnnicanons in Cell and Molecular Biology. Tomei LD, Cope FD (eds), vol 3, pp. 47-60, Cold Spring Harbor Laboratory, Cold Spring Harbor, NY (1991).

33 Macdonild HR, Les RK: Programmed cell death of antoreacive thymocyles. Nohure 343:642$644(1990)$.

34 McDonnell TJ, Deane N, Plat FM, Nuñez G, Jaeger U, McKearn JP, Korsmeyer SI: Bcl-2 immunoglobulin transgenic mice denonstratc exiended B cell survival and follicular lynphoproliferation. Cell 57:79-88 (1989).

35 Miller T, Beausang LA. Meneghini M, Lidgard $G$ : Death-induced changes to the nuclear matrix: the use of anti-nuclear matrix antibodies to study agents of apoptosis. Biotechmiques 15:1042$1047(1993)$.

36 Moore IV: Death of cells and necrosis of tumours. In: Perspectives in Mammalian Cell Death. Potton CS (cd), pp. 295-325. Ox ford University Press, Ox ford (1987)

37 Oberhammer F, Wilson JW, Dive C, Morris ID, Hickman JA, Wakcling AE, Walker PR, Sikorska M: Apoptotic death in epithelial cells cleavage of DNA to 300 and/or $50 \mathrm{~kb}$ fragments prior to or in the absence of internucleosomal fragmentation. $L M B O J / 12: 3679-3684$ (1993). 
Oberhammer FA, Hochegger $\mathrm{K}$, Fröschl $\mathrm{G}$, Tiefenbacher $\mathrm{R}$, Pavelk $\mathrm{M}$ : Chromatin condensation during apoptosis is accompanied by degradation of lamin $\mathrm{A}+\mathrm{B}$, withotit enhanced activation of cdc2 kinase. J Cell Biol 126:827-837 (1994).

39 Ormerod MG, ONeill CF, Robertson D, Harrap KR: Cisplatin induces apoptosis in an human ovarian carcinoma cell line without concomitant intenuclesomal degradation of DNA. Exp Cell Res 211:231-237 (1994)

40 Pasdar $M, L i Z$ Disorganization of microfilaments and intermediate litaments interferes with the assembly and stability of desmosomes in MDCK epithclial cells. Cell Motil Cyloskel 26:163$180(1993)$.

41. Ramaekers F, Huysmans A, Schaart G, Moesker O, Vooijs P: Tissue distribution of keratin 7 as monitored by a monoclonal antibody, Exp Cell Res 170:235-249 (1987).

42 Robaye B, Doskeland AP, Suarez-Huerta N, Doskeland SO, Dumont JE: Apoptotic cell death analyzed at the molecular level by two-dimensional gel clectrophoresis. Electrophoresis 15:503. $510(1994)$.

Sarraf CE, Bowen. ID: Proportions of mitotic and apoptotic cells in a range of untreated experimental tumours. Cell Tisste Kinet 21:45-49 (1988)

Schaafsma HE, Ramackers FCS, van Muijen GNP. Ooms ECM, Ruiter DI: Distribution of cytokeratin polypeptides in epithelia of the adult urinary tract. Histochemistry 91:151-159 (1989).

Schutte B, Reynders MMJ, Van Assche CLMVJ, Hupperets PSJG, Bosman FT, Bligham GH: An improved method for the immunocytochemical detection of bromodcoxyuridine labeled nuclei using flow cytomedry. Cylometry 8:372-376 (1987).

Squier MK, Miller AC, Malkinson AM, Cohen JJ: Calpain activation in apoptosis, J Cell physiol 159:229-237 (1994)

47 Towbin $\mathrm{H}_{2}$ Staehelin T, Gordon I: Electrophorctic trans fer of protcins from polyacrylamide gels to nitrocellulose sheets: procedure and some applications. Proc Nall Acad Sci USA 76:4350 $4354(1979)$.

48 Ucker DS, Obermiller PS, Eckhart W, Apgar JP, Berger NA, Meyers J: Genome digestion is a dispensable consequence of physiological cell death mediated by cytotoxic Tl lymphocytes. Mol Cell Biol 12:3060-3069 (1992).

49 Verheijen R. The nuclear matrix: composition and structural organization. In: Thesis, pp. 131143. University of Nijmegen, Nijmegen, The Netherlands (1988).

50 Verheijen R, Kuijpers H, Vooijs P, van Venrooij W. Ramackers F: Distribution of the 70K UI RNA associated protein during interphase and mitosis, Correlation with other U RNP particles and proteins of the nuclear matrix. I Cell Sor 86:173-190 (1986).

51 Villa $P$, Miehe M, Sensenbrenter $M_{2}$ Petman B: Synthesis of specific proteins it trophic factordeprived neurons undergoing apoptosis. J Neurochem $62: 1468$. 1475 (1994)

52 Walker PR. Weaver VM, Boleslaw L, Leblanc I, Sikorstia M: Endonuclease activities associated with high molecular weight and internucleosomal DNA fromentation in apoptosis. Exp Cell Res 213:100-106 (1994).

Walski M, Celary-Walska R, Borowicz J. Studies on the hypothalamus and secretory nuclei of rat in the remote period following clinical death. J Himforsch 32:687-698 (1991).

Wijsman $\mathrm{HH}$, Jonker RR, Keijzer R, van de Volde C $\mathrm{H}$. Comelisse CJ, van Dierendonck JH: A new method to delect apoptosis in parafin sections; in situ end-labeling of fragmented DNA. I Histochem Cylochem 41:7-12 (1993).

Woronicz JD, Calnan B, Ngo V. Winoto A: Requircment for the orphan steroid receptor Nur77 in apoptosis of T-cell hybridomas. Naure 367:277-281 (1994) 
56. Wyllic AH, Kerr JFR, Currie AR: Cell death: the significance of apoptosis. Int Rev Cytol $68: 251-306(1980)$.

57 Wyllie AH, Rose KA, Morris RG, Steel CM, Foster D, Spandidos DA: Rodent fibroblast tumours expressing myc and ras genes. Growth, metastasis and endogenous oncogene expression. BrJ Cancer $56: 251-259(1987)$.

58. Wyllie AH: Apoptosis (The Frank Rose Memorial Lecture). Br J Cancer 67:205-208 (1993). 


\section{Summary and general discussion}




\section{Summary and general discussion}

This thesis describes the evaluation of tumor growth parameters in lung cancer and the development of more refined methods to measure cell proliferation and cell death. Part I comprises the clinical studies that have been performed on bronchoscopy specimens of in vivo BrdU labeled lung cancer patients. In Part $I I$, several pitfalls that arose from these clinical studies are addressed.

Chapter 2 describes the bivariate BrdU/DNA flow cytometric analysis of a series of lung cancer biopsy specimens. The method allowed to obtain dynamic cytokinetic data after in wivo labeling with BrdU in a majority of cases. A difference in proliferation parameter scores between the group of patients with small cell lung cancer (SCLC) and the group of patients with non-small cell lung cancer (NSCLC) was expected, since SCLC and NSCLC are known to display different clinical behavior and growth rate. However, when the average scores for BrdU labeling index (LI), S-phase transit time $\left(T_{i}\right)$ and potential tumor doubling time $\left(T_{p o d}\right)$ of the two cancer types were compared, no significant differences were observed. Therefore, the slower growth rate of tumors of the NSCLC type is probably due to a higher rate of cell loss than is the case in tumors of the SCLC type. Loss of cells from a tumor can occur via two different pathways, i.e. necrosis and apoptosis. Evidence exists that apoptosis or programmed cell death plays an important role in tumor growth. In all lung cancer samples, cells with an S-phase DNA content were detected, which had not incorporated BrdU. The origin of these cells, as well as their fate was not clear, but we suggest that their occurrence might be related to (programmed) cell death. In chapter 6, we elaborate on this subject.

The series of bronchial biopsies that was described in chapter 2 was extended with an additional series of 57 cases in order to evaluate the prognostic value of the cytokinetic parameters (chapter 3). These parameters of in total 92 cases were related to the patient survival time. The $T_{\text {pou }}$ was found to be a significant indicator of prognosis in NSCLC. In particular, a short $T_{\text {pot }}$ and short $T_{s}$ significantly predicted for a shorter survival period in non-squamous NSCLC. Therefore, the determination of $T_{p o t}$ and $T_{s}$ of individual bronchial biopsies may in future be useful for the design of more adequate treatment schedules in lung cancer. The correlation of a high LI with short survival time in non-squamous NSCLC was borderline significant. This may be due to the admixture of non-tumor cells in the samples used for flow cytometry. To correct for these non-malignant cells, two approaches have been pursued, i.e. 1) immunohistochemical estimation of the BrdU $\mathrm{LI}$ in tissue sections, thus combining morphological information and cell proliferation parameters, and 2) the flow cytometric selection of cancer cells on basis of their cytokeratin expression. The fact that non-malignant cells bias the outcome of flow cytometric analysis became apparent from the comparison of BrdU labeling indices in tumor cell suspensions and tissue sections, since a higher 
BrdU LI was measured when tumor cells could be identified on basis of morphology (chapter 4).

Since in recent years, the expression of the proliferation associated markers PCNA and Ki67-antigen has been used to measure proliferation, we compared the BrdU $\mathrm{LI}$ to the scores of these markers in tissue sections (chapter 4 ). These two intrinsic markers were chosen because PCNA expression is thought to identify the S-phase compartment, while Ki67-antigen is supposed to reflect the growth fraction. Controversial reports exist on the reliability of these parameters, since their detectability seems to depend on the fixation and staining methods applied. We conclude that the scores of PCNA and Ki67-antigen, immunohistochemically detected in ethanol fixed, paraffin embedded tissue sections reflect functional proliferative activity, comparable to the in vivo BrdU labeling index. It is therefore suggested that these two markers provide valuable information about the proliferative capacity of a malignancy, but do not reflect its dynamic properties (i.e. $T_{s}, T_{p o t}$ ). For this purpose, the feasibility of multiparameter flow cytometric analysis was evaluated (chapter 5 ).

A three color flow cytometric assay was developed for discriminating between diploid non-epithelial cells and (diploid) tumor cells, based on the simultaneous detection of cytokeratin, DNA and a proliferation associated marker, such as PCNA, Ki67-antigen or BrdU. By gating on cytokeratin positivity, epithelial cancer cells can be selected for a detailed cell cycle analysis. This method appeared to be applicable to cell suspensions obtained from frozen tissue blocks, which makes it useful for multicentre clinical studies. Furthermore, recent studies have shown that cytokeratin selection is also feasible in formalin fixed, paraffin embedded tissue (Leers et al., unpublished data). We therefore suggest to apply such a selection procedure in future studies determining the prognostic value of flow cytometry derived parameters.

In reference to the observation of non-BrdU labeled cells with S-phase DNA content, that was described in chapter 2 , a series of experiments was carried out to investigate the origin and fate of this cell population (chapter 6). The most likely explanation for the occurrence of these cells seems to be cell cycle arrest in Sphase, rather than inadequate diffusion of BrdU throughout the tissue. The possibility that tumor cells, being arrested in the cell cycle under suboptimal conditions, can regain their cycling capacity when the growth restriction is released, is of clinical and therapeutic importance. Therefore, we addressed the question whether the observed cell cycle arrest in nutrient deprived cell cultures is reversible. We conclude that cells arrested in S-phase because of unfavourable growth conditions can regain their cycling capacity upon nutrient suppletion, depending on the duration of cell arrest. Cells with an S-phase DNA content that were unable to incorporate BrdU and had evidently resided in Sphase for a longer period of time, appeared to be irreversibly arrested, eventually resulting in cell death.

In chapter 7 we aimed at the development of a valid detection method for cell death by discriminating between vital, necrotic and apoptotic cells. Detection of DNA nicks 
allowed the distinction between vital cells on the one hand and necrotic and apoptotic cells on the other hand. Since changes in nuclear organization and in membrane structure suggest a role of the nuclear matrix and the cytoskeleton, these two cellular compartments were studied in relation to cell death. In contrast to necrotic cells, apoptotic cells still display specific components of the nuclear matrix and in early apoptosis cytoskeletal filaments remain present in the cell. We conclude that, based on the differences that apoptotic and necrotic cells display in their cytoskeleton, nuclear matrix and nuclear DNA, immunostaining combined with in situ nick translation in a multiparameter flow cytometric assay can discriminate between vital, necrotic and apoptotic cells.

Tumor growth is the net result of cell formation and cell loss. Many clinicians attribute a fast growth rate to a high proliferation rate, and the efficacy of anticancer agents to antiproliferation. Our results in lung cancer and other recent data challenge these paradigms. The rate of cell loss is a major determinant of clinical growth rate and the chemosensitivity of cancer cells is at least in part dependent on the capacity to enter the apoptotic pathways. The exact quantitation of proliferation and apoptosis is therefore needed to predict the growth potential and chemosensitivity of individual cancers. 


\section{Samenvatting}

Ondanks betere behandelingsmethoden voor longkanker is deze ziekte in de westerse landen nog steeds de belangrijkste doodsoorzaak ten gevolge war malignuteiten. De laatste jaren is bij mannen een daling waargenomen in het aantal longkankersterfes, terwijl bij vrouwen dit aantal blijft stijgen.

Het overgrote deel van de longtumoren wordt op basis van hum histologie ingedeeld in vier hoofdgroepen, te weten plaveiselcelcarcinoom, adenocarenoon, grootcellig ongedifferentieerd carcinoom en kleincellig carcinoom. De eerste drie typen wordent ook wel samen niet-kleincellige longcarcinomen genoemd. Patienten met een whetkleincellig longcarcinoom hebben over het algemeen betere overlevingskangen dat patienten met een kleincellige aandoening, hetgeen voor een deel te verklaren ts door het agressieve groeigedrag van de kleincellige longtumoren.

Groei van weefsels wordt bepaald door de balans tussen celaanmank (proliferatte) en celverlies (celdood). Om de groei van een tumor te kumer voorspellen, en eventucel te beinvloeden, is het nodig de mate van celproliferatie en celdood te kunnen meten. Dit proefschrift beschrijft de evaluatie en verfijning van een aantal meetwethoden voor tumorgroei. Het gebruikte materiaal is afkomstig van longkankerpatienten die bromodeoxyuridine (BrdU) toegediend kregen. We noemen dit in wwo labelung. BrdU is een synthetische stof die in plaats van thymidine in het DNA wordt ingebouwd tijdens de DNA synthese-fase (S-fase) van de celcyclus. Enkele uren na de in wo labeling met BrdU wordt een biopt genomen door middel van bronchoscopie. Vervolgens wordt in de cellen, die uit het biopt geisoleerd worden, de mate van BrdU inbouw en de DNA inhoud bepaald door middel van flowcytometrie. Op basis van deze gegevens kunnen o.a. de snelheid waarmee individuele cellen delen en de potentiele verdubbelingstijd van de tumor worden berekend. Deze laatste factor is een maat voor de tijd die nodig is om het dubbele aantal cellen te verkrijgen wanneer er geen rekening wordt gehouden met het optreden van celdood.

In de hoofdstukken $2 \mathrm{t} / \mathrm{m} 5$ van dit proefschrift worden celdelingsstudies in tumormateriaal beschreven. Het feit dat in de kliniek wordt waargenomen dat nietkleincellige longtumoren veel langzamer groeien dan kleincellige doet een snellere proliferatie vermoeden in het laaste tumortype. Er werd echter geen noemenswaardig verschil gevonden tussen de berekende proliferatiewaarden van niet-kleincellige en kleincellige longtumoren. Waarschijnlijk is het minder agressieve groeigedrag van niet-kleincellige tumoren te verklaren door een veel groter celverlies vergeleken met kleincellige tumoren.

Een bepaalde groep cellen, die veelvuldig werd geobserveerd in het patiëntenmateriaal van zowel kleincellige als niet-kleincellige tumoren, bevond zich in de S-fase maar bouwde geen $\mathrm{BrdU}$ in (de zgn. ongelabelde S-fase cellen). Het vermoeden bestat dat 
deze cellen een rol spelen bij het fumorcelverlies. In hoofdstuk 6 van dit proefschrift wordt thier verder op ingegaan.

De gegevens omtrent de celdelingsactiviteit werden gekoppeld aan de overlevingsdour van de patiënten, om zodoende te onderzoeken of het verloop van de ziekte voorspeld kan worden aan de hand van informatie wit een klein stukje tumorweefsel. In nietkleincellige longcarcinomen bleek met name een korte potentiële verdubbelingstijd verband te houden met een kortere overlevingsduur. In plaveiselcelcarcinomen was bovendien ook een korte $\mathrm{S}$-fase duur gecorreleerd met een slechtere prognose. Het bepalen van de celdelingsactiviteit in een biopt kan daarom van nut zijn bij de beslissingen omtrent specifieke behandelingsmethoden.

Bij de analyse van de tumorbiopten werden we geconfronteerd met een aantal methodologische problemen. Zo veroorzaken bijvoorbeeld de over het algemeen wisselende hoeveetheden niet-tumorcellen die aanwezig zijn in het bioptmateriaal een onderschatting van de groeipotentie van de tumor. Door het gebruik van weefselcoupes, waarin tumor- en niet-tumorcellen microscopisch onderscheiden kunnen worden, kan dit probleem deels ondervangen worden. Door toepassing van antistoffen tegen celdelingsmerkers kan in deze coupes de proliferatie-activiteit van alleen de kankercellen bepaald worden. Met deze methode kunnen echter veel minder cellen worden geanalyseerd in vergelijking met flowcytometrie. Verder wordt uit weefselcoupes alleen "statische" en geen "dynamische" informatie verkregen, d.w.z. het wordt wel duidelijk dat een cel zich in een bepaalde fase van de celcyclus bevindt, maar niet hoe snel deze fase doorlopen wordt.

Een andere mogelijkheid om niet-tumorcellen uit te sluiten bij proliferatie-metingen is gebruik te maken van een extra parameter bij flowcytometrie, bijvoorbeeld cytokeratine, een eiwit dat specifiek is voor epitheliale (kanker)cellen, maar dat niet voorkomt in bloedcellen of bindweefselcellen.

De hoofdstukken 6 en 7 behandelen de tegenhanger van celproliferatie, nl. het proces van celdood. Op basis van de eerder genoemde observatie van ongelabelde S-fase cellen in tumorweefsel is een reeks experimenten uitgevoerd op longtumorcellen, om de origine en het gedrag van deze ongelabelde S-fase cellen te onderzoeken. Wanneer tumorcellen onvoldoende voedingsstoffen aangeboden krijgen stoppen ze met delen in de fase van de celcyclus waar ze zich op dat moment bevinden. Cellen die in S-fase zijn synthetiseren dan geen DNA meer en bouwen geen BrdU meer in, resulterend in ongelabelle S-fase cellen. Deze cellen bleken niet meer in staat te zijn hun delingsactiviteit te hervatten bij voldoende voedseltoevoer en verdwenen uit de populatie tumorcellen, waarschijnlijk ten gevolge van celdood.

Celdood voltrekt zich via twee verschillende processen, nl. apoptose en necrose. Er zijn aanwijzingen dat apoptose een belangrijke factor is bij tumorgroei. De methoden om een apoptotische cel te identificeren en te onderscheiden van een necrotische cel zijn tot op heden omstreden en niet in elke situatie toepasbaar. Aan de hand van 
essentiele kenmerken van apoptotische cellen, zoals veranderungen in het cel-en kernskelet en fragmentatie wan het DNA, werd een methode ontwikkeld waamee onderscheid gemaakt kan worden tussen apoptotische, mecrotische en vitale cellen.

Tumorgroei is het netto resultaat van celproliferatie en celdood. Een snelle groei van de tumor wordt meestal toegeschreven aan een hoge proliferatiesnelheid. Over het algemeen wordt aangenomen dat de werking van een antikanker-therapie wordt bepaald door de mate waarin de proliferatie wordt geremd. Onze resultaten omtrent longkanker en de resultaten van andere recente studies tonen an dat ook de mate van celverlies een bepalende factor bljikt te zijn voor de groei van een tumor, terwijl de gevoeligheid wan kankercellen voor chemotherapie in elk gewal gedeeltelijk samenhangt met hun "apoptose-gevoeligheid". Kwantificering van proliferatie en apoptose zal daarom in de toekomst belangrijk worden bij het voorspellen van de groeicapaciteit en therapie-gevoeligheid van individuele tumoren. 


\section{Droowknad}

Een proefschrift schrijf je nooit alleen.

Ook dit boekje is het resultaat van de hulp en betrokkenheid van veel mensen. Een aantal van hen wil ik in het bijzonder noemen.

Allereerst dank aan mijn promotores, Frans Ramaekers en Geert Blijham.

Beste Geert, jij was het die het project op poten zette en mij de mogelijkheid gaf de illustere wereld der tumorcelgroei te verkennen. Jouw klinische inbreng en "to the point' opmerkingen hebben een belangrijke bijdrage geleverd aan veel van de hoofdstukken in dit proefschrift.

Beste Frans, hoewel ik officieel was aangesteld bij Interne Geneeskunde nam je me spontaan op in jouw vakgroep en gaf me de gelegenheid mijn hele onderzoek uit te voeren in de labs van Moleculaire Celbiologie. Ik kreeg van jou de vrijheid om interessante zijwegen in te slaan, zoals "the apoptotic pathway". Hiervoor, en voor de vele uren die je al corrigerend doorbracht met mijn manuscripten, ben ik je zeer erkentelijk. De leden van de manuscript-beoordelingscommissie onder voorzitterschap van Prof. dr. M. von Meyenfeldt, wil ik bedanken voor het kritisch doorlezen van het manuscript.

Een nederige révérence voor mijn co-promotores, Guul ten Velde en Bert Schutte.

Beste Guul, jouw 'pilot-study' was de basis waarop mijn onderzoek steunde. Je hebt er voor gezorgd dat er geregeld klinisch materiaal binnenkwam, en ik weet dat dat vooral in het begin heel wat moeite heeft gekost. Ook zorgde je voor financiële steun vanuit de vakgroep Pulmonologie, zodat ik nog een paar maanden respijt had om het onderzoek af te ronden. Je vaderlijke blik en oprechte interesse in de voortgang van het onderzoek hebben me erg gestimuleerd.

Beste Bert. Hier kom ik op een punt dat ik even stilval. Vreemd voor iemand uit "de School van Schutte", maar wat te zeggen tegen de man van wie ik alles over het wetenschappelijk onderzoek heb geleerd? Jouw heldere nitleg, je nuchtere kijk op het (celbiologische) universum en je no-nonsense aanpak van problemen bewonder ik zeer. Waarschijnlijk is het slecht voor je ego, maar het moet nu maar cens gezegd worden: ik vind je de slimste wetenschapper die ik ken

Alle mensen van de vakgroep Moleculaire Celbiologie \& Genetica: 't woar sjoen!!! Ook al liepen de experimenten even niet, dankzij jullie kwam ik tỏch graag naar het werk. Er viel altijd wel iets te lachen, te mopperen of te porren (???! van Eys!) en wie begrijpt je stress now beter dan De Collega?! Ik zal jullie allemal (en de vlaai rond $11.00 \mathrm{w})$ heel erg missen.

Voor de statistische bewerking van hoofdstukken 3 en 4 gaven Hubert Schouten en Marion de Leeuw (Methodologie \& Statistiek, RL) nutlige adviezen. Gio Pijpers voerde een groot deel van de "drie parameter flowcytometrie" experimenten uit. Zijn bijdrage is opgenomen in hoofdstuk 5. Op de longartsen van het AZM en de medewer- 
kers van de behandelkamer kon ik rekenen als er gebiopteerd, geborsteld en gefixeerd moest worden. Een paar etages hoger was de afdeling Pathologie, met name Cor Beek, Adriaan de Bruine, Erik Thunissen en Sjoerd Wagenaar, altijd beschikbaar voor deskundige hulp en adviezen. Allemaal heel erg bedankt!

De steun van mijn paranimfen, Marie-Hélène Lenders en Frank van der Loop, was onmisbaar.

Lieve Marie-Hélène, samen hebben we aan dit onderzoek gewerkt, en samen hebben we heel wat tegenslagen overwonnen (ik zal nooit vergeten hoe het voelde toen "de PCNA het eindelijk deed"). Een belangrijk deel van de experimenten is door jou uitgevoerd, op een nauwkeurige en toegewijde manier. Ik had me geen betere analiste, kamergenote en vriendin kunnen wensen.

Lieve Frank, als ik het weer eens even niet zag zitten kwam jij met die typische brabantse logica of een nummer oerend-hard Normaal. Beide methoden hielpen altijd voortreffelijk. Je was mijn vaste sportkameraad en de andere helft van "de harde kern" in de kroeg. I hoop dat onze vriendschap tot ver buiten Oost-Brabant zal reiken.

Tijdens mijn eenzame avonden en nachten achter de PC besefte ik eens temeer dat geen enkel proefschrift -althans niet het mijne- tot stand kan komen onder voortdurende werkdruk en stress. De vele gezellige etentjes, kroegavonden, zeiltochten, concerten en andere "get-togethers" hebben mijn Quest voor The Holy Manuscript aanzienlijk verlicht. De personen achter al deze leuke dingen dank ik voor hun vriendschap en hun vrolijkheid (overigens, heren voorzitters van Nico Bronsgeest Goes Latin: ik ambieer nog steeds een lidmaatschap).

Mam, pap en Mark. Een lieve familie die in je gelooft en waar je kunt "ontstressen" is zó belangrijk. Dank jullie wel.

Tenslotte, Harmjan: hoe is het met jouw koeien? De mijne zijn nog steeds niet thuis; blăvf? 


\section{Curriculum Vitae}

Monique Tinnemans werd geboren op 22 juni 1967 te Roermond. In 1985 behatalde ztj het gymnasium $\beta$ diploma aan de scholengemeenschap "Broekhin" te Boennond. In datzelfde jaar begon zij haar studie Gezondheidswetenschappen and de Rijksuniversiteit Limburg te Maastricht. Het doctoraal examen, met als afstudeerrichting Brolog: sche Gezondheidkunde, werd behaald in januari 1990. In maart 1990 werd zij aangesteld als AIO bij de vakgroep Interne Geneeskunde (Prof. Dr. G.H. Blifham) wan het Academisch Ziekenhuis Maastricht, op een door de Nederlandse Kankerbestrijding gefinancieerd project. Het onderzoek werd uitgevoerd bij de vakgroep Moleculaire Celbiologie \& Genetica van de Rijksuniversiteit Limburg (Prof dr. F.C.S. Ramaekers, Dr. B. Schutte). 